SCHOOL OF CIVIL ENGINEERING

JOINT HIGHWAY RESEARCH PROJECT JHRP-74-7

ENGINEERING SOILS MAP OF DELAWARE COUNTY

D. G. Shurig 
Digitized by the Internet Archive in 2011 with funding from

LYRASIS members and Sloan Foundation; Indiana Department of Transportation 


\section{Finil Report}

\section{ENGINEERING SOILS MAP OF DELAWARE COUNTY}

T0: J. F. McLaughlin, Director

Joint Highway Research Project

FROM: H. L. Michael, Associate Director Joint Highway Research Project
May 1, 1974

Project: $\quad C-36-51 B$

File: $\quad 1-5-2-55$

The attached report, entitled "Engineering Soils Map of Delaware County, Indiana," completes a portion of the project concerned with development of county engineering soils maps of the State of Indiana. This is the 55 th report in the series. The report was prepared by Professor D. G. Shurig, Joint Highway Research Project.

The soils mapping of Delaware County was performed primarily by using the soil survey map sheets published by the soil Conservation Service, United States Department of Agriculture in the soil survey of Delaware County. Airphoto interpretation techniques were used to supplement the pedological data. The resulting engineering soils map is presented as a blackline print.

Respectfully submitted,

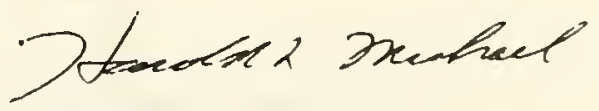

Harold L. Michael

Associate Director

HLM:ms
CC: W. L. Dolch
M. L. Hayes
C. F. Scholer
R. L. Eskew
C. W. Lovel1
M. B. Scott
G. D. Gibson
G. W. Marks
J. A. Spooner
W. H. Goetz
R. D. Miles
M. J. Gutzwiller
G. T. Satterly
H. R. J. Walsh
G. K. Hallock
R. F. Marsh
E. J. Yoder
S. R. Yoder 
Final Report

ENGINEERING SOILS MAP OF DELAWARE COUNTY

by

\author{
D. G. Shurig \\ Research Associate
}

Joint Highway Research Project

Project No.: C-36-51B

File No.: 1-5-2-55

Prepared as Part of an Investigation

Conducted by

Joint Highway Research Project

Engineering Experiment Station

Purdue University

in cooperation with the

Indiana State Highway Commission

Purdue University

West Lafayette, Indiana

May 1, 1974 


\author{
ENGINEERING SOILS MAP \\ OF \\ DELAWARE COUNTY, INDIANA
}

\title{
INTRODUCTION
}

Development of an engineering soils map of Delaware County was the primary goal of this project. The map is appended to this report; the report supplements the engineering soils map information.

The detailed pedological soils maps published in the 1972 Soll Survey of Delaware County by the United States Department of Agriculture Soil Conservation Service in cooperation with Purdue University, Agricultural Experiment Station (5) were the single most important source of data used in the project. These agricultural soils map sheets, at a scale of $1: 15,840$, were assembled to form a mosaic map of Delaware County. Careful study of the soll series descriptions enabled the grouping of the series into appropriate 1 and form and parent material categories. Preliminary land form and parent materlal boundaries were then delineated on the mosaic-map.

Routine airphoto interpretation techniques supplemented the pedological data. Aerial photographs were examined and the preliminary boundaries checked and modified, if necessary, to produce final land form and parent-material boundaries. The photographs were contact prints at an approximate scale of $1: 20,000$. Date of photography was 1941 . 
The final land form and parent material boundaries were graphically reduced to produce the engineering solls map ( 1 inch $=1$ mile). Symbols were used to delineate the parent materials as grouped according to land form and origin. Textural symbols were superimposed to indicate the relative compositions of the parent materials.

The map also includes a set of soll proflles which indicate the general soil profiles of topographically high and low sites in the larger land form parent material areas - namely ridge and ground moralnes and alluvial plains. Other land forms did not show enough profile variation between topographic highs and lows to warrant drawing the two separate profiles.

Each profile shows the general range in depth and texture of each soil horizon - the A-, B- and C-horizon - the latter being the parent material. The soll texture classification system used in the map profiles is that of the Indiana state Highway Commission (the ISHC soil classification system chart is shown on the map in the lower right hand corner). The ISHC system differs slightiy from the USDA system so that the use of USDA textures have to be converted to ISHC textures - for example, a USDA classified loam could be a loam or clay loam under the ISHC system.

The soil profiles drawn on the side of the engineering soils map have been numbered. Areas on the soils map have corresponding numbers to indicate the soil profile for that particular area in the field. 
In the text of the report pedological soil names have been provided for each parent material soll area shown on the map. In Appendix $B$ quantitative engineering soll test data is provided for each pedological soll name. In Appendix $C$ qualitative data as to soll problems and certain advantageous soll uses are provided according to pedological soll names.

\section{DESCRIPTION OF AREA}

\section{GENERAL}

Delaware County is located in east-central Indfana - see Figure 1. Muncie, the county seat, is 50 miles northeast of Indianapolis.

County dimensions are about 21 miles in the north-south direction and about 19 miles east-west. The total area is 398 square miles.

"Farming is the leading occupation in Delaware County, though many people are employed by industry and some of the workers commute to Anderson, Marion and Indianapolis. About half the farm income comes from the sale of field crops or special crops and half from the sale of livestock and livestock products. Corn, soybeans, wheat and hay are the dominant crops. Dairy and beef cattle, hogs, chlckens, and turkeys are raised extensively." (5). 


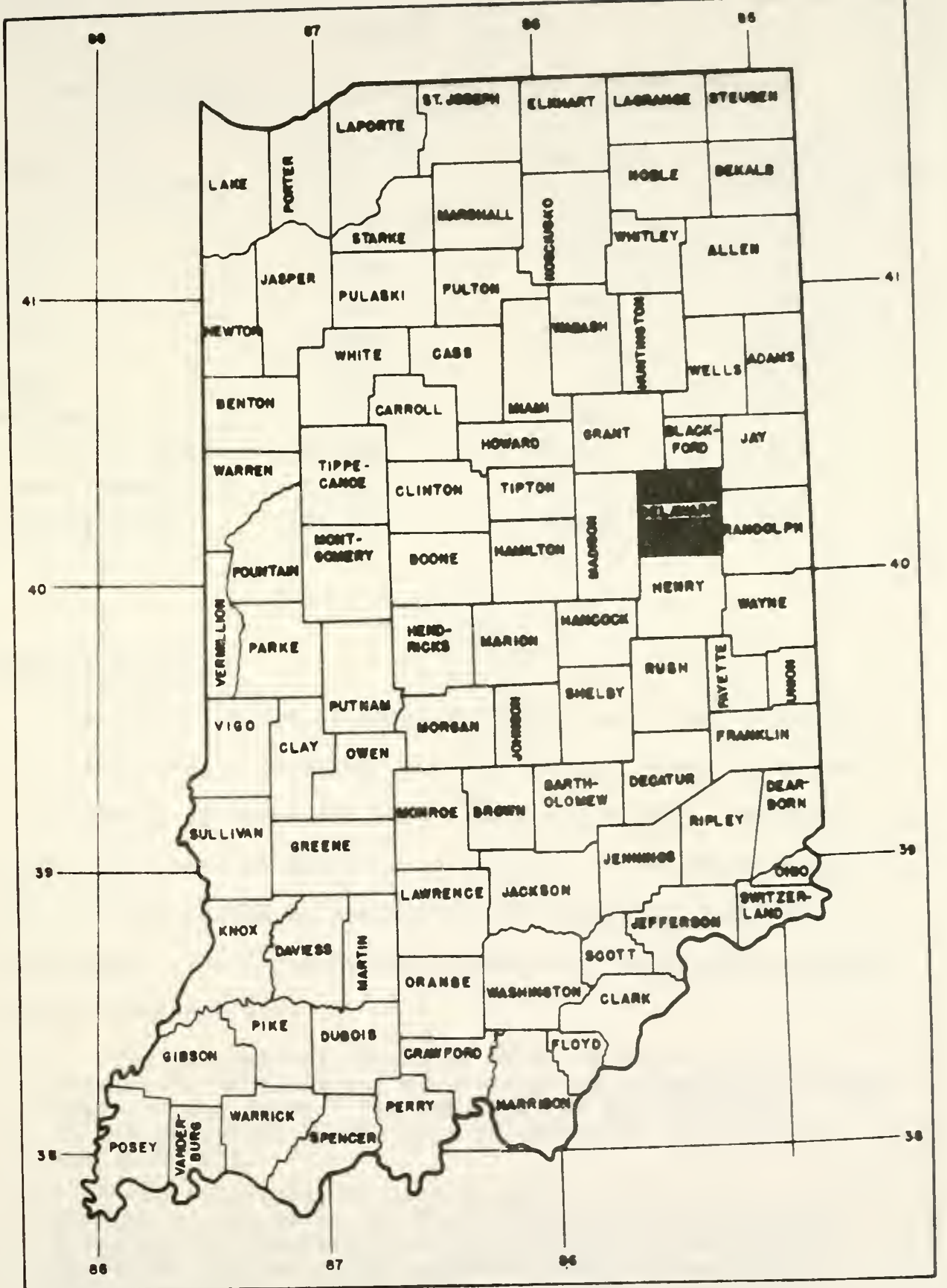

FIG. I. LOCATION MAP OF DELAWARE COUNTY 
TABLE 1 (4)

Some Significant Population Data for Delaware County

$\begin{array}{lccc}\begin{array}{c}\text { Population } \\ \text { Cities and Towns }\end{array} & \begin{array}{c}\text { Population } \\ 1970\end{array} & \begin{array}{c}\text { Population } \\ 1960\end{array} & \begin{array}{c}\text { Percent } \\ \text { Change } 160-170\end{array} \\ \text { Albany } & 2,293 & 2,132 & 7.6 \\ \text { Eaton } & 1,594 & 1,529 & 4.3 \\ \text { Gaston } & 928 & 801 & 15.9 \\ \text { Muncie } & 69,080 & 68,603 & 0.7 \\ \text { Selma } & 890 & 562 & 58.4 \\ \text { Yorktown } & 1,673 & 1,137 & 47.1 \\ \quad \text { Cities \& Towns } & 76,458 & 74,764 & 2.3 \\ \quad \text { Rural Areas } & 52,761 & 36,174 & 45.9 \\ \quad \text { County Total } & 129,219 & 110,938 & 16.5\end{array}$

\section{DRAINAGE FEATURES}

Drainage features of Delaware County are shown in Figure 2, "Drainage Map - Delaware County, Indiana", prepared by the Joint Highway Research Project, Purdue University, 1954 (13). Larger scale maps of one mile to the inch or two miles to the inch can be obtained by contacting the School of Clvil Engineering. The following description of the drainage appears with the drainage map.

"The northeastern third of Delaware County lies within the Mississinewa subdivision of the Wabash Drainage basin of the state. The remainder of the county is in the West Fork subdivision of the White River drainage basin (3).

Surface drainage is best developed along the valleys of the White and Mississinewa rivers and their principal tributaries. The Mississinewa River valley is rather shallow. The watershed divide between the White and Mississinewa rivers is a nearly level plain tract. Another nearly level tract lies between Buck and Bell creeks in the southern part. Buck Creek is 


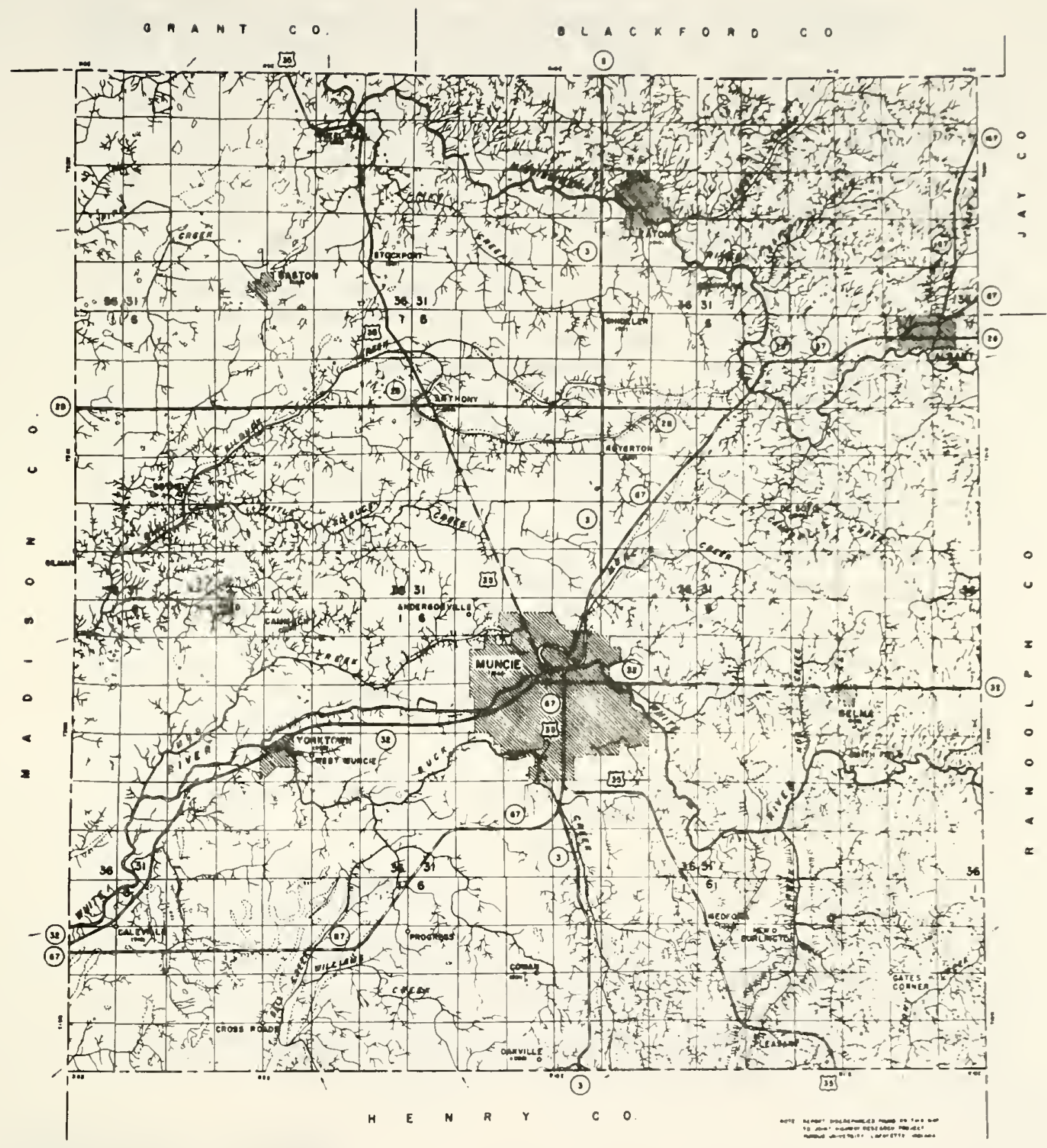

\author{
DRAINAGE MAP \\ DELAWARE COUNTY
}

FIG. 2. 
deflected near White River. Channels of glacial meltwater drainage are conspicuous within the county. These exist along Prairie, Hog. Buck, Bell, Muncle, Mud, Big Killbuck, and Easleys creeks. Stream valleys near the head of Bell Creek are shallow and fairly wide. Dissection is prominent along portions of Pratrie, Stony, and Easleys creeks. The Prafrle Creek valley in its upper portion is shallow. [Prafrie Creek Reservolr was bufit in 1961] The presence of sections of moraines appears to have affected drainage systems in the county. Stream deflection, local watershed divides, and intenstfled densities of dralnage patterns occur in the moralnic areas. Streams have shallow valleys near New Burlington. Many streams have tortuous courses. Prominent are some abrupt changes in the courses of the Mississinewa River. Several streams in the southern part also make abrupt changes in their courses: Bell Creek is an excellent example. Many streams in the southern part have northerly courses. Hhite River has veered from the Union City moraine to flow down the dip of the underlying rock. Pike Creek nearly parallels the Mississinewa River. Streams in the northern part have a northwesterly trend exhlbiting morainic contro?. Ditty Creek flows in a northeasterly direction before 1 ts course is reversed near Hhite River. The headwater streams of Plpe creek are deflected westerly. Local basins are scattered in the t\{li platn areas.

There are no natural lakes in Delaware County. Ponds of various orlgins are scattered throughout the area.

Ditches have been constructed to improve sluggish drainage conditions.

A stream gaging station is located on White River at Muncie (12). The drainage area of White River above Muncte is about 300 square miles (11)." (12).

Two dams in the county are the Prairie creek Reservoir Dam and the Muncie Water Works Dam.

\section{CLIMATOLOGICAL SUMMARY}

Muncie, the county seat of Delaware County, is also a weather station. The following two pages contain a climatological summary of Delaware County temperature and precipitation covering a 27-year (plus) perfod (1939-1966). 


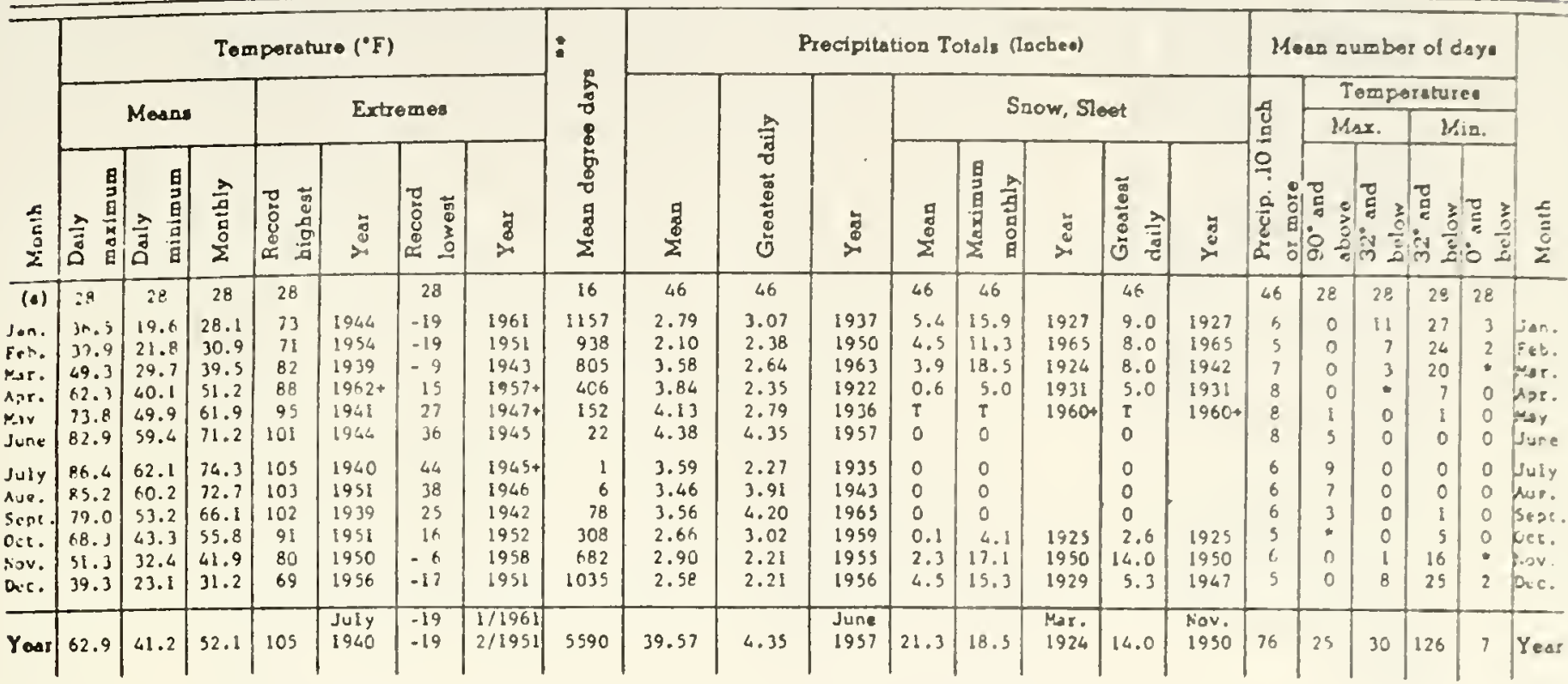

(a) Average length of record, yeere.

T rrace, in athount too amall to meseure.

- Sse Hearlne degree dayg paragraph below.
- Aleo on cerlier detee, monthe, or yesze.

- Lea than one haif.

x Precipletion dete for pertod of 1921-1966.

CLIMATE OF MUNCIE, INOIANA

Huncle, located in Delouare County in tast Cental indisna, enjoys an invigoratlng climate of four well defined seasang of the year be cause of lis location in the middle laticudes and away from the intluence of oceans. Alr of boch tropical and polar orlgin plics the area resulting in frequent changes of temperature and humidicy and ncer idesi ralnfalt. Lov pressure centers from the vest cross the plalns, move up the Ohlo River Valley and the St. Laurcnce River Valley to the Arlantic. Most of Munele's ralnfall comes from these storms. Afternoon thunderstotms are the primaty source of sumer rainfall. Days with these storms averake about 47 a year. About one year occurs durlag the vinter months. Scvere storma are rare but 17 cornadoes have been recorded in the Caunty in the 50-year period of $1916-1966$

Relative humidicy data is not avallable but estimates are possible. Relative humidicy varles an an average summer day from the 40'a durlng a kypical sumer afternoon to 90 or higher just before daun. Relutive humidicy rises and falls much as temperacure does during a 24 -hour pertad but highest percent usually occurs with the ninimum cempersture and the lowcst percent with the maximum temperature.

In the winter the most probable range of humidity is from the $60^{\prime}$ s to the $90 \mathrm{~s}$. Southerly uinds bring higher humiditles than notth. westerly winds.

Prevalling ulnds in the Muncie area are from the southwest during the year except in the vinter and early spring when west and northwat directions are predominant. The mid-winter monch of January has winds out of the northuest a majority of the tame.

Ralnfall Intensities for the Muncie area, based on the statistical creatrent of taintall data, indicate that the prohability of 1.3 inches of rein in one hour is atout once in two years; a rain of 2.1 Inches in one hour occurs atout once in ten years, and 2.5 inches in one hour, ahout once in 25 years. In a th-hour period, ralnfall of 2.0 inches occurs once in two years: 3.4 inches, once in. ten-year period, alld 4.1 inches, about unce in 25 years. In a 24 -hour perlod 82.8 inch ran occurs abuut once In two years; 4.3 inches fall once in ten years, and five inches fail about once in 23 years.
Preclpitation Is uaually greaces in late ipring end ceriy suter. The vincer monchs are the driest. Aprl1, May end June each average el hhe tays having. 10 inch or more of rain. The rumber of days, having this errount, drops to five in late sumer and in the wincer. Droughts are Inirequent and effect egricuiture only occselansbly.

Snoufall has accurred es early as Octaber and as lace as may. The most snow comes in January: hovever, the greatest sno:fall of arv one day occurred November 26,1950 , when 14 inches were recorded. The greatest monthly totel recorded occurred in usch of 1924 , wi:h - toisl of 18.5 inches. The sverage yes.y snowidi 1.21.3 increo.

Temperature in July, the wormes month of the ytar, resche: 90 degrees or higher on en everage of nine days year. The winter season averares seven dayo with temperacures below zero. January is usually the coldest ingle month of the year. Mincie clipace is cooler than vestern and outhern Incisna.

Heatine depree days in the table above provide a corparalive nurbes for calculating heating requirements between cifferent pinces and different tlmes. Fuel consumption for heoting is proportsonal io degree day cotals, so monch with twice the heating descee cays o: another monch requires tulce as auch fuel for heating. Deprted dors for single day are obtaned by subcracting the rean cemperacure from 65 degrees.

The Whice RIver flowing through Ancle occaslonaliy floods low lands. The river gauge. 200 feet fown strear froo the balnut Strcet Bridie, would have read about 19.6 feet according to high water marks on March 25, 1913. This is thu hishest stage ef record; next hiphest is 18.07 fcet on January 15, 193: , ane third hirhest of record 1910.25 feet on Fehruary 16, 1950. The zezo of the river gause near the botcon of the giver is 920.10 feet above mean sea levcl.

Laurence A. Schajl

Weacher turcau Scare Clileacolarist

Juiy 1967

Purdue Univeral

Lafayecte, Indians ariut 


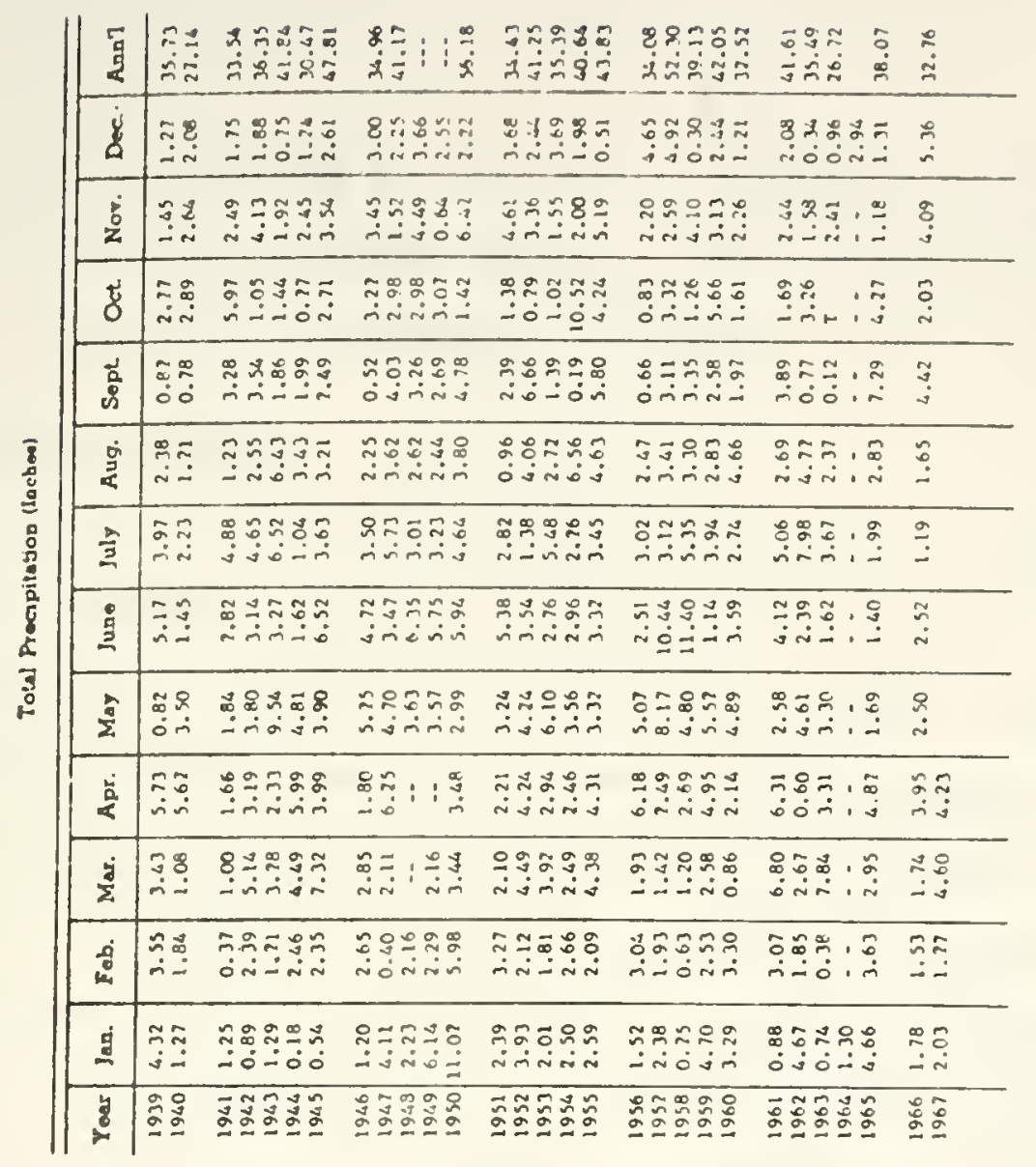

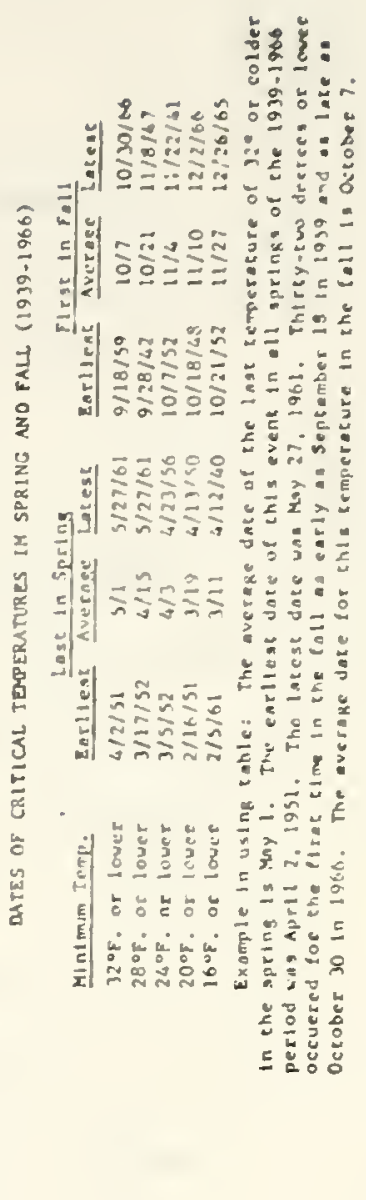

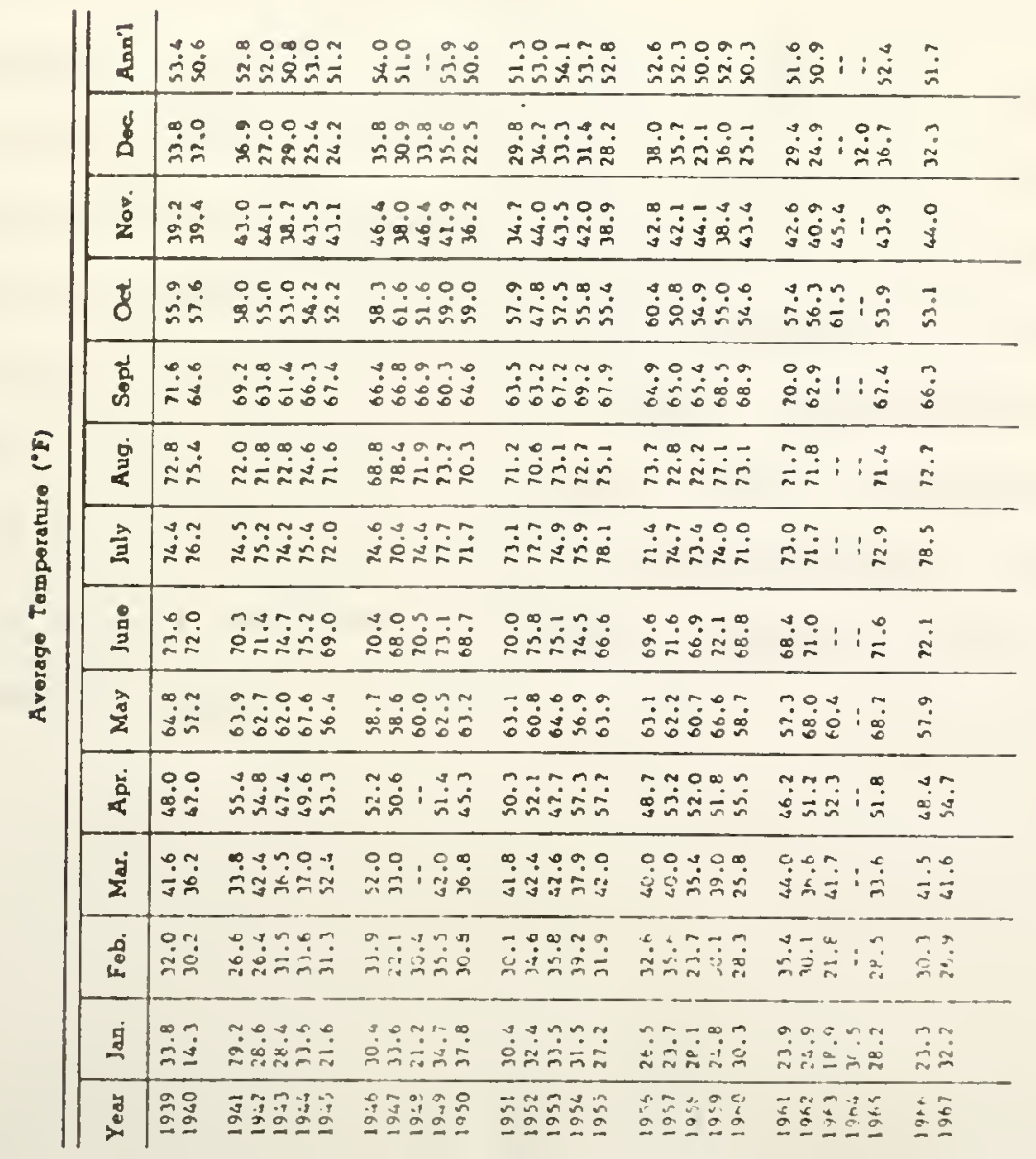

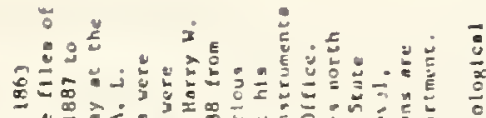

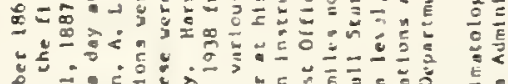

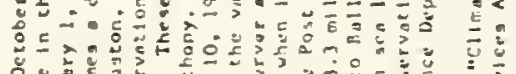

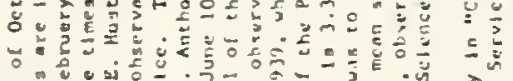

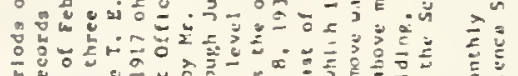

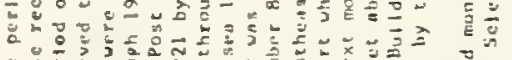

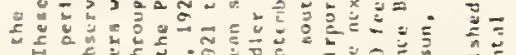
5

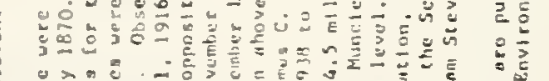

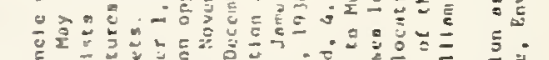

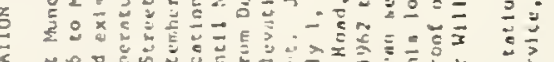

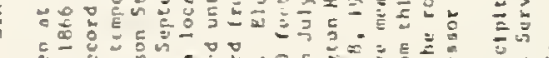

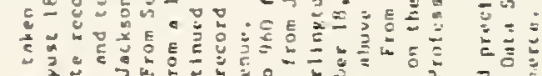

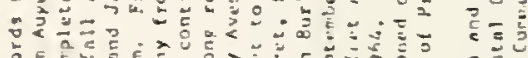

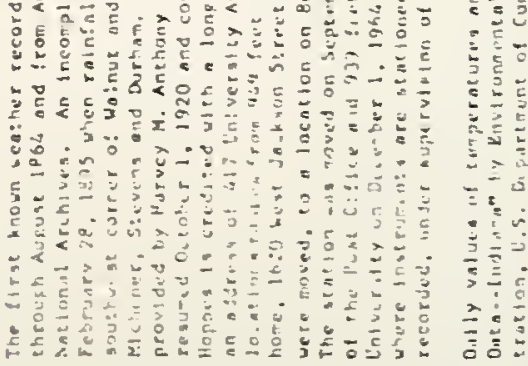


Data was complled by the U.S. Department of Commerce, Environmental Science Services Administration in cooperation with the Muncie Chamber of Commerce, July 1967 (14).

\section{GLACIAL GEOLOGY}

Ice covered Delaware County during at least three glacial ages: Kansan, Illinotan and Wisconsin. The thickness of the glactal drift deposited ranges from no cover, at a few bedrock exposures, to more than 200 feet of glaclal drift over some preglacial valleys - see figure 3. Average overall thickness, however, probably would average close to 100 feet (11). Only Wisconsin age drift is exposed at the surface of Delaware County. Surface drift in the southern part of the county is probably somewhat less than 20,000 years old - deposited during the Tazewell subage. Surface drift in about the northern part of the county is probably somewhat less than about 15,000 years $01 d$ - deposited during the cary subage. From various literature it appears that the Tazewell-Cary interglaclal perlod could have ranged from 5000 to 12,500 years. Recent depostts such as: alluvial materials along streams, colluvial accumulations on slopes, swamps and lake sediments such as peat and muck and sand dunes are mostiy less than 10,000 years 0ld. Geologically these recent deposits are known as facies of the Martinsville Formation (9). 


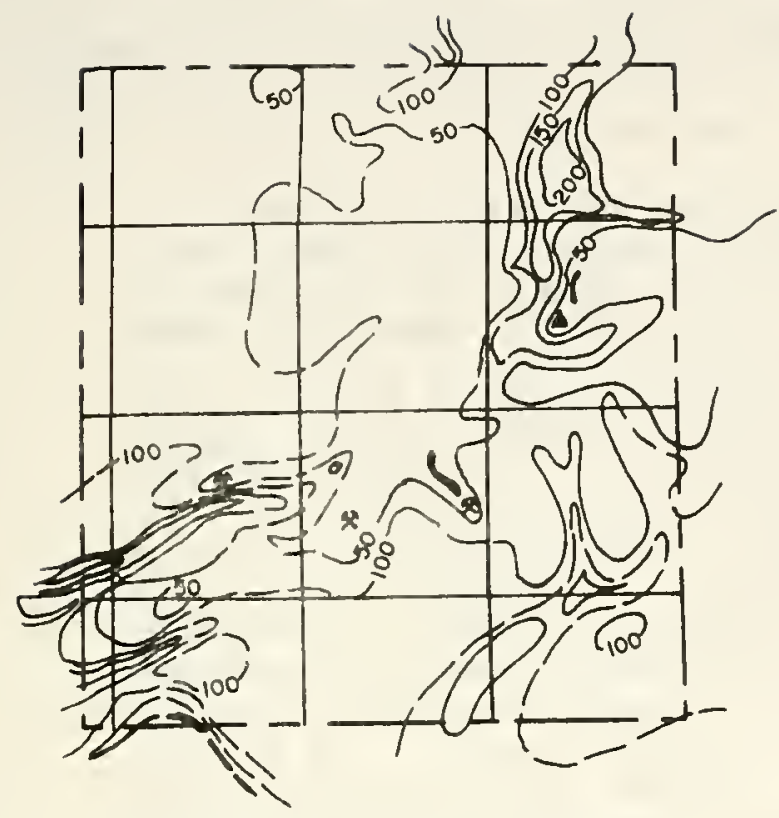

GLACIAL DRIFT THICKNESS

(WAYNE - 1956)

$50 \mathrm{Fr}$. Confour Interval

4 Bedrock Oufcrops

* Quorry

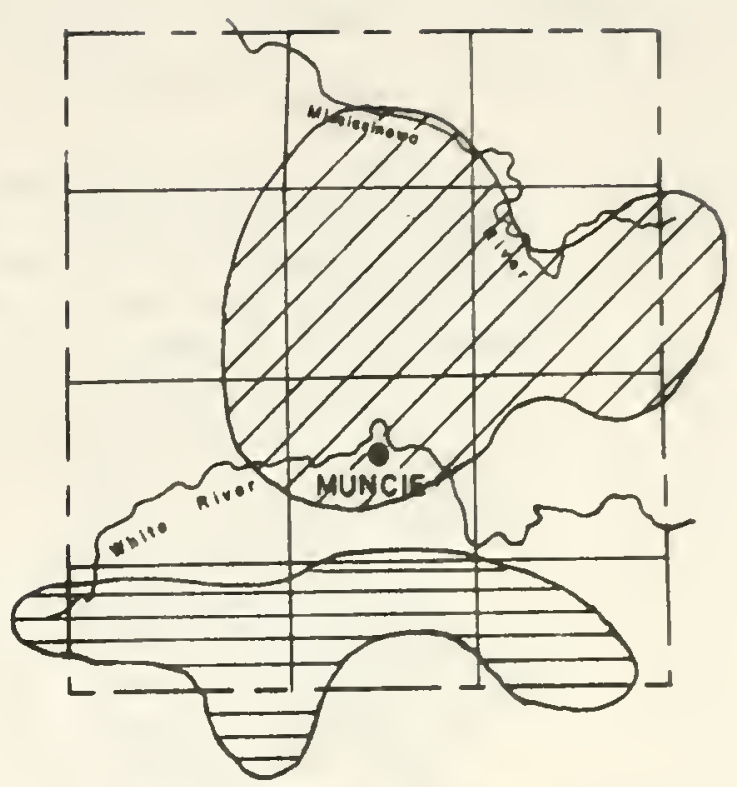

GLACIAL DRAT THICKNESS (GRAX-1973)

EZJ Less Thon 50 ft.

$\square 50 \mathrm{ft}$. To $200 \mathrm{ft}$.

Over $200 \mathrm{ft}$.

FIG. 3. GLACIAL DRIFT THICKNESS-DELAWARE CO. 
The following summary of Wisconsin glaciation along with

Figure 4 (9) provide an excellent picture of glacial history

in all northern Indiana as well as Delaware County.

"The main advance of ice during the Wisconsin Age covered about two-thirds of Indiana ( $F$ ig. $4 \mathrm{~A}$ ). It reached its maximum position at the Shelbyvilie Moraine about 21,000 years ago, then the marginal area melted almost immediately. About 1,000 years later the ice margin moved back southward to a new position a little short of the Shelbyville Moraine (Fig. 4B). The advance burled a thin bed of silt that covered the older till. Fossil snalls and $\mathrm{plant}$ remains in the silt show that central Indiana at that time probably was covered with tundra-like vegetation and scattered spruce trees. A few patches of permafrost may have existed close to the ice. This advance of the ice is marked by the Crawfordsville Moralne. The group of tills deposited by these two glacial advances are the Trafalgar Formation.

The lce that deposited the Trafalgar tills came from the northeast; striations and esker trough lineations show the direction the glacier was moving (Fig. 4B), and the till composition reflects the bedrock to the northeast into Canada. Large amounts of outwash sand and gravel were lald down during the advance and the bullding of the crawfords ville Moraine, and kames were abundant. After the active ice margin had melted and the glacier had buflt the knightstown Moraine, the entfre lobe in central Indiana ceased to move. Kames, outwash plains, and moraines are the signature of an active glacier, but the eskers and esker troughs of central Indiana are evidence that the glacier became a mass of stagnant ice.

Another glacial advance followed the stagnation in central Indiana of the East White Sublobe of the Ontario-Erie Lobe. Ice moved first out of the Huron and Saginaw lowland across southern Michigan and north-central Indiana. The Maxinkuckee and Packerton Moraines are part of the varied topography of kames, moraines, outwash plains and kettles left by the Huron-Saginaw Lobe (Fig. $4 \mathrm{C}$ ). Most of Indiana's lakes are the legacy of this advance.

Some masses of ice or ice-cored moraines of the Huron-Saginaw Lobe probably still lay in place to help block the north edge of the lobe that soon appeared from the Erie basin. The Ontario-Erie Lobe built the Mississinewa Moraine with its apex at Wabash, then as it melted, left a symmetrical series of recessional moraines around its former 

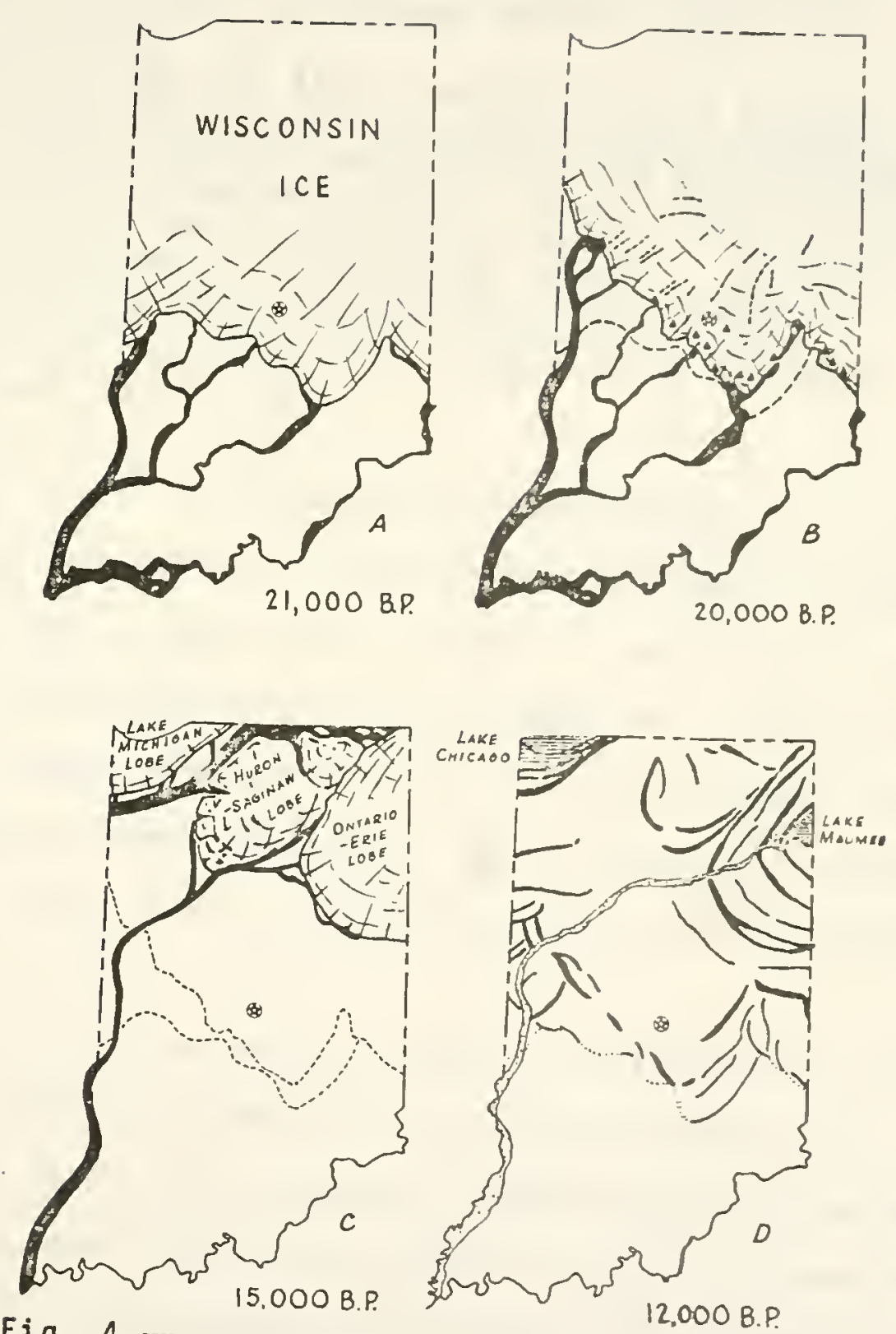

Fig. 4 Wisconin 12,000 B.P.

cier (about 21,000 years aro). B-IVisconsin Maximum extont of gla20,000 years ago). C-Locition - Wisconsin second maximum (about ago). I) -Wisconsin -Wisconsin ice (atuot 15,000 years (about 12,000 years ago). Af tends and extent of alacial Great laakes

BP - Before Present (1950 wayne (9) 
positions (Fig. 4C). This till, clay-rich, is part of the Lagro Formation. After the lce melted from the Fort Wayne Moraine about 14,000 years ago, glacial Lake Maumee formed between the lce margin and the moraine (Fig. 4D). Its overflow spllied through the moraine and swept out a broad floodplain, now called the Maumee Terrace, along the Wabash Valley.

At the same time that the ontario-Erie Lobe was building its series of festooned moralnes, glacial 1 ce plowed southward again through the Lake Michigan basin. At its maximum extent it piled more till on an existing ridge to build the Valparaiso Moraine. outwash drained to the Kankakee channel. As the ice margin melted, Lake Chicago came into existence between the glacier and the Valparaiso Moraine (Fig. 4D). Old beaches and stable duries now mark its former levels" (9).

The main point to be gathered from the above is that an early lobe of ice coming out of Michigan (Tazewell subage) deposited slightly less clayey (slightly less plastic, slightly more silty, sandy, gravelly and bouldery) than a later ice lobe (Cary subage) coming out of the Erie basin area. The latter lobe deposited the slightly more clayey soli on top of the less clayey soil in the northern two thirds of the county.

Recently published geologic maps (1971) show the Largo Formation extending southward to include the Union city moraine (1). Some earlier geologic reports show the Largo Formation extending south only through the Mississinewa moraine. Pedologists call the primary solls of the Largo Formation Morley, Blount and Pewamo. These three solls were sampled in Delaware County by soil scientists and tested in Purdue's Civil Engineering soil laboratory - engineering test data is 
shown in Appendix A. South of the Unton City Moralne the geologic formation is the Trafalgar Formation (Cartersburg Member). Pedologically the soils are mainly Miami, Crosby and Brookston solls.

Geologic studies in Miami and Wabash counties (8)(12), with somewhat simflar glacial geology features as Delaware County, report some minor fluctuations (advances and retreats) of the ice in the general area during both Tazewell and Cary subages with resulting interbedding of till and outwash material. In Delaware County, the outwash plains in the southern part of the county appear to show this interbedding. It appears that the outwash sand and gravels may have a thin veneer of till over them.

\section{BEDROCK GEOLOGY}

Figure 5 (1) shows a generalized bedrock geology map of Delaware County. Most of the rock is silurian limestone, dolomite and shale. In the north central part of the county the Mississinewa Shale Member is at or near the bedrock surface. In the northeastern corner and also in the southern half of the county former stream branches of the Teays River have cut into Ordovician shale and limestone rock - compare the geology to the Glacial Drift Thickness map - Figure 3.

"stlurian rock formations are exposed in the Mississinewa valley near Eaton and in and near the valley of the West Fork of White River west of Muncie. Occasional bedrock valleys are present and appear to cross the county in a general north-south 


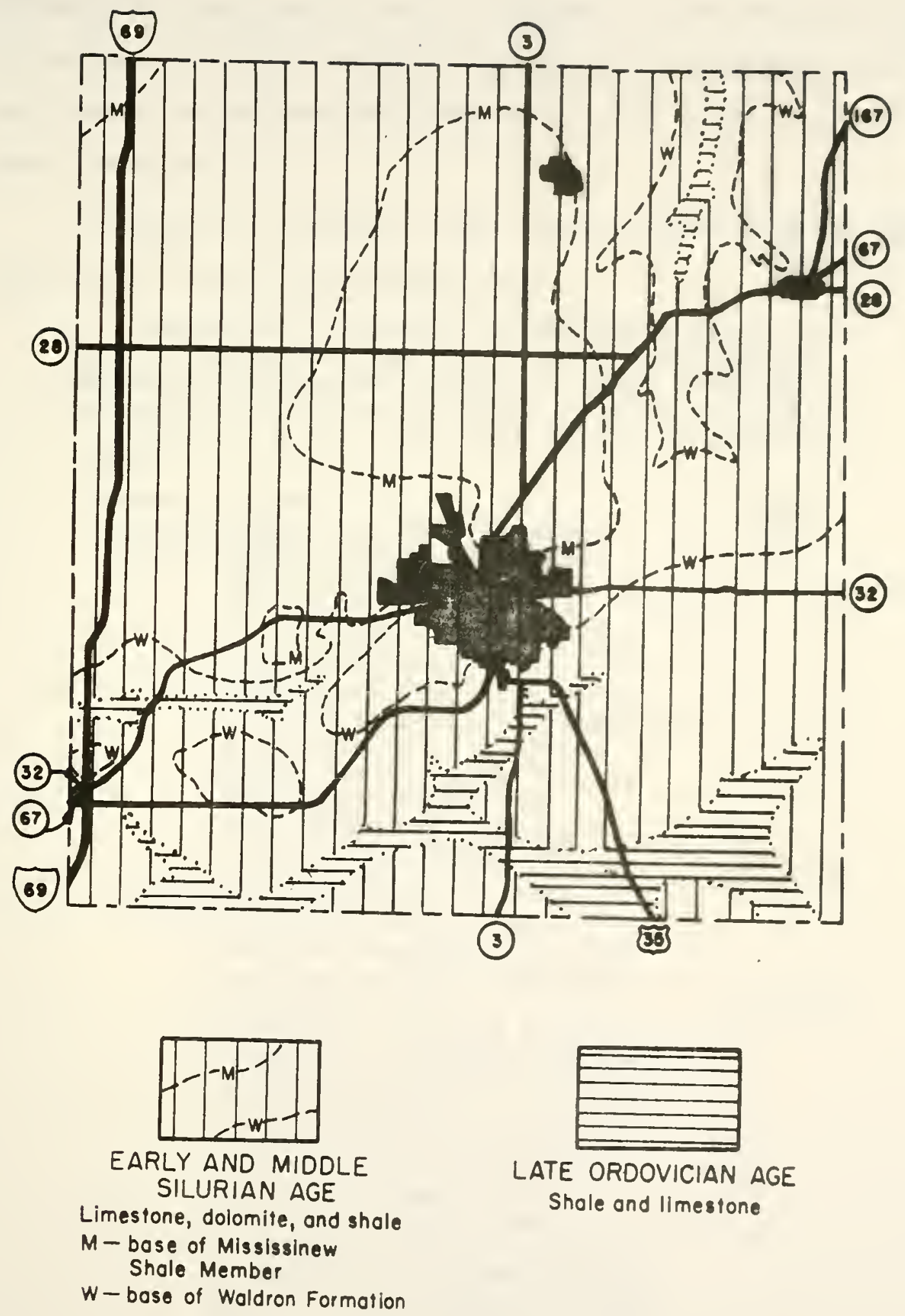

FIG. 5. GEOLOGIC MAP OF DELAWARE COUNTY 
direction. The glacial drift thickens to the west and south in Delaware County. Morainic masses in the southern part of the county add to the thickness of glacial cover in this area" (McGrain).

Following is a 200-ft. rock section taken from an Indiana Geological Survey drilled core (6):

"Section 16. Exposure in abandoned quarry at site of cored hole and $\mathrm{log}$ of core from Indiana Geological Survey drill hole 96 , near Yorktown, Delaware County, Ind. (SE1/4NW1/4SW1/4 sec. 14, T. 20 N., R. 9 E.). Altitude at top of section, $910 \mathrm{ft}$.

\section{Silurian System:}

Wabash Formation, Mississinewa

Shale Member, $4.6 \mathrm{ft}$. examined:

1. Dolomitic limestone. argillaceous, gray and 01 ive drab, dense, earthy, weathering shaly; has concholdal fracture; units 1 and 2 observed in exposure:

this unit and its upward extension of a few feet at this site ylelded the graptolites of Cumings and Shrock (1928a)......... 4.4-9.0

Louisville Limestone, $71.3 \mathrm{ft}$ :

2. Dolomite, gray, finegrained, weathering slabby; has many crinoid fragments.... 9.0-16.2 No observation............ 16.2-18.5

3. Dolomite, somewhat mottled light-gray and buff, strongly mottled below $48.0 \mathrm{ft}$; has ocherous stains to $42.0 \mathrm{ft}$; fine to medium grained, saccharoidal in part, vuggy; unit 3 and lower units observed in core; has lithology similar to that of reefs and, together with unit 2 , is involved in local dips, so that Cumings and Shrock (1928a, p. 172) designated the site as showing reef development..... 18.5-58.5 
4. Dolomite, mostly buff,

fine-grained, and vuggy,

argillaceous in upper $2.5 \mathrm{ft}$,

weakly stylolitic; has

dark-colored irregular

carbonaceous laminae;

grades in lower foot to

unit 5................ 58.5-80.3

Waldron Formation, $5.6 \mathrm{ft}$ :

5. Shale, dolomitic, dark-gray, especially fossiliferous in lower $6 \mathrm{in}$. and reminiscent of classic outcrop fossils; has fucoldal markings in part.................. 80.3-85.9

Salamonie Dolomite, $85.7 \mathrm{ft}$ :

6. Dolomite, light-colored, has ocherous stains in upper part; mostly fine grained saccharoldal; vuggy in upper twothirds; somewhat stylolitic; has sparse corroded chert in upper part and abundant chert nodules and bands from 126.5 to 134.5 ft.; upper few inches consist of coquina of fossils as in unit 5; unit corresponds at least in part to Laurel Limestone of southern Indtana.... 85.9-134.5

7. Dolomite, argillaceous, gray, earthy, fine-gralned; has many crinold fragments. dark-colored irregular shaly laminae, and white nodular bands of corroded chert; units 6 to 8 correspond at least in part to the osgood Formation of southern Indiana; grades into unft $8 \ldots \ldots \ldots \ldots \ldots \ldots$ 134.5-151.3

8. Dolomite of variabie aspect, gray and light-colored, fine-grained, saccharoldal in part, also coarse-grained, stylolitic and vuggy in part; has coarse crinold fragments in upper and lower parts and some dark wavy carbonaceous laminae in lower part; grades into unit $9 \ldots \ldots \ldots \ldots$ 151.3-171.6 
Brassfield Limestone, $7.4 \mathrm{ft}$ :

9. Dolomite, mottled gray and

light gray-green, finegrafned, vuggy, pyritic;

has some pinkish-tan streaks

and crinoid fragments

reminiscent of the

Brassfleld on outcrop ....... 171.6-177.5

10. Dolomite, pyritic, tan and

gray and fine - to coarse-

grained, also gray-green

and dense; unit possibly

is Cincinnatian in age...... 177.5-179.0

Ordovician System, Cincinnatian Series:

Unassigned rocks, $20 \mathrm{ft}$ cored:

11. Dolomite and shale, inter-

bedded and mixed; dolomóte

is gray and tan, fine to

coarse grained, and

fossil fragmental and

grades to shale; shale is

gray green; has

characteristic

Cincinnatian fossils;

unit includes two 3-ft

core losses................179.0-190.0

12. Dolomite, tan to brassy-

brown, medium-grained,

some what vuggy, pyritic;

has intercalations of

green shale in upper part.... 190.0-199.0" (6).

The "Directory of Crushed Stone, Ground Limestone and Cement Producers in Indiana" (2) provides the following information on several limestone quarry operations in Delaware County: "Company - Irving Brothers Stone and Gravel Corporation; location - 1.75 mile northeast of S.R. 67 and S.R. 3 ; products crushed limestone and agricultural l1mestone; geology - sand and gravel $50 \mathrm{ft}$., Loufsville 1 imestone $57.8 \mathrm{ft}$.; remarks cored Waldron shale $9.2 \mathrm{ft}$., Salamonfe dolomite $107 \mathrm{ft}$., Brassfield limestone $19.2 \mathrm{ft}$., Cincinnatian rocks $30.6 \mathrm{ft}$." 
"J and K Stone Corporation - Eaton Quarry; location - west edge of Eaton; products - crushed limestone and aglime; capacity - 1000 tons per day; geology - soll plus glactal drift $3.5 \mathrm{ft}$, lower Niagaran rocks $29.1 \mathrm{ft}$.

"J and K Stone Corporation - Muncie Quarry, location southwest of Muncie at Cornbread Road and Middletown Pike; products - crushed and agricultural limestone, also flux; capacity - 2,600 tons per day; geology - soll plus glacial drift $6 \mathrm{ft}$, Louisville limestone $60 \mathrm{ft}$.

"Muncie Stone and Lime Company Incorporated, Cornbread Road near Hoyt Avenue, products - crushed and aglime, capacity - 1,500 tons per day, geology - soil plus glacial drift $6.5 \mathrm{ft}$., Louisville limestone $76.6 \mathrm{ft} . "$ (2).

\section{PHYSIOGRAPHY AND TOPOGRAPHY}

Delaware County 1 ies in the Central Lowlands province of the United States and in the Till Plains section of the province. In Indiana the Till plains section is known as the Tipton Till Plains.

Figure 6 shows a physiographic sketch - namely the outstanding land form features of Delaware County. The physiographic sketch also shows a number of elevation points on various prominant land forms. Figure 7 is a generalized topographic map of Delaware County showing approximate 50-foot contour interval areas. Note the general elevations increases diagonally across the county from the northwestern corner (850-900 feet) to the southeastern corner (1050-1100 feet). 
RIVER

830

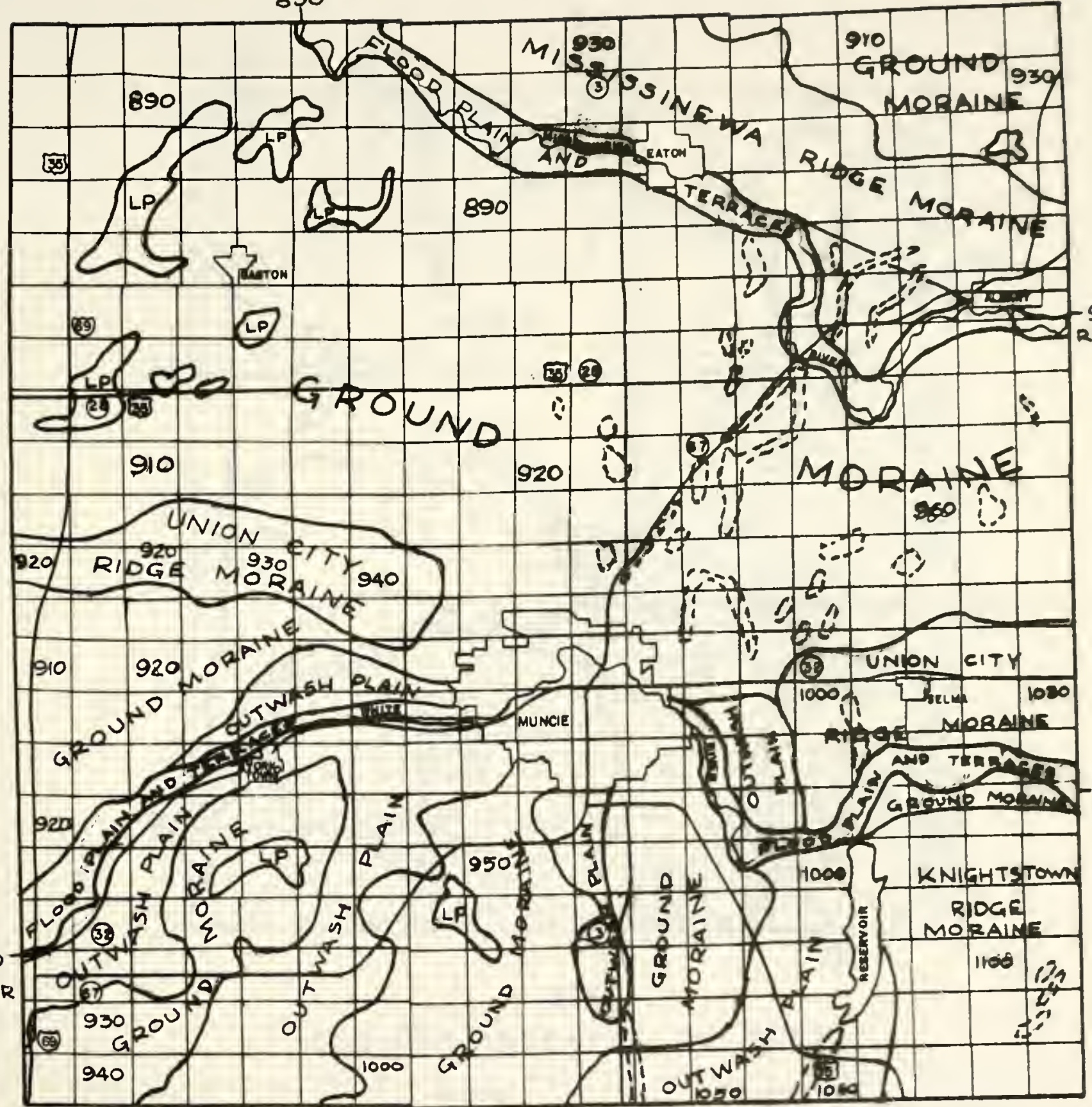

FIG.6. PHYSIOGRAPHIC SKETCH OF DELAWARE COUNTY

LP-LACUSTRINE PLAIN

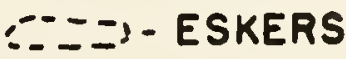

:- - KAMES

$830-1100$ - ELEVATIONS 


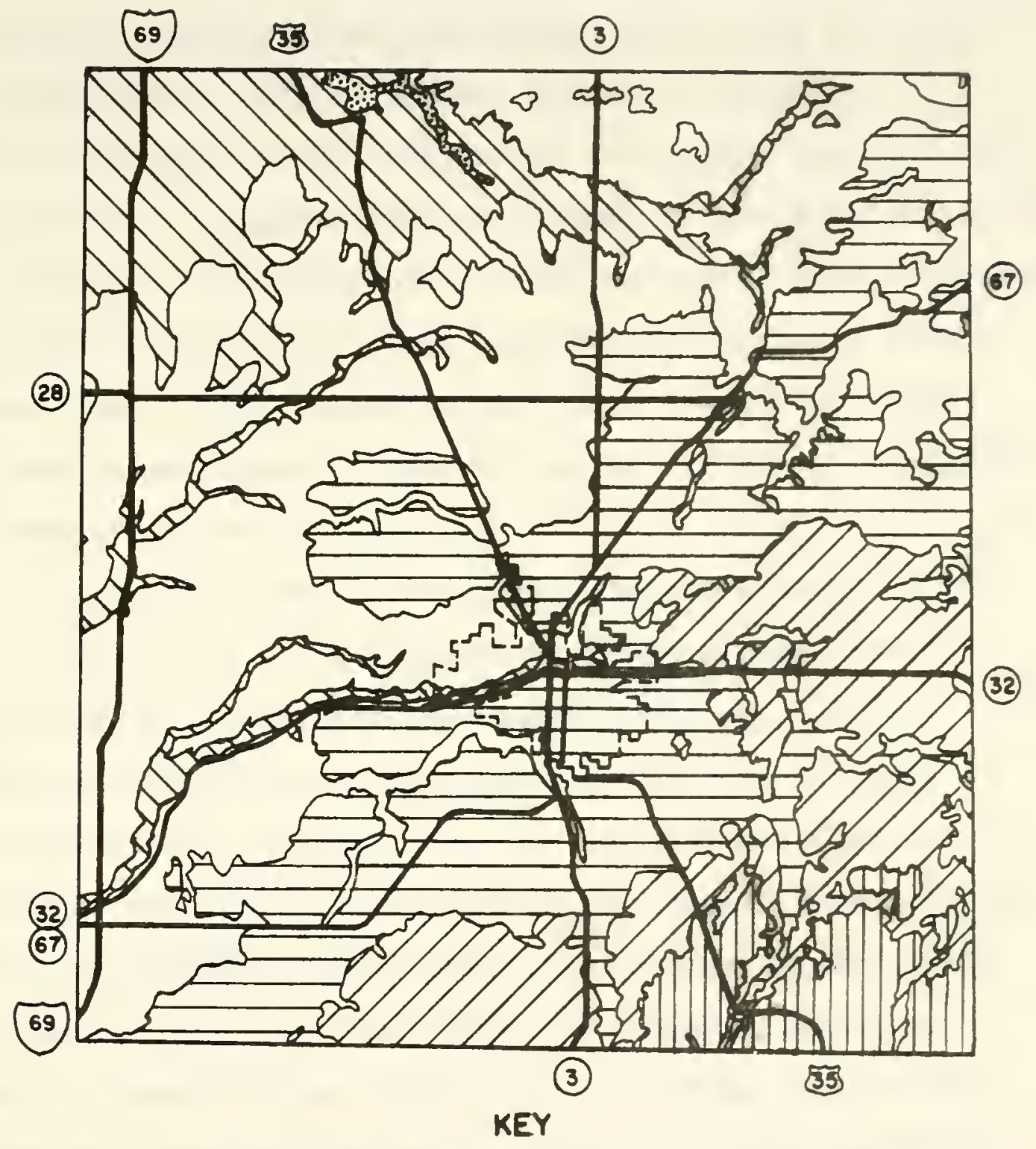

CONTOUR INTERVAL 50 FEET

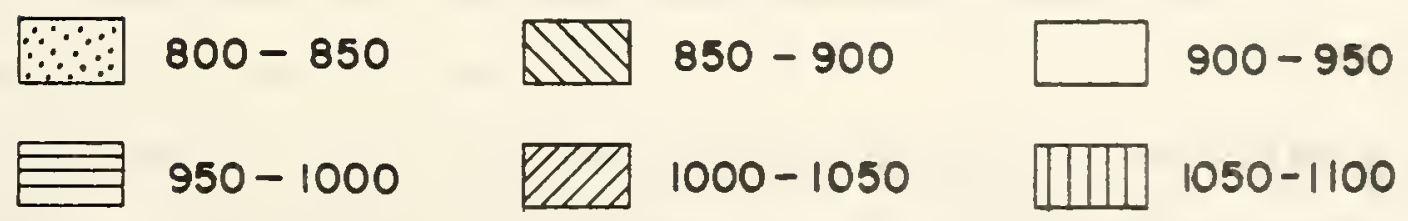

FIG. 7. TOPOGRAPHIC MAP OF DELAWARE COUNTY (from 10 Topo Map NK 16-12) 
The main land form features of the county are: two major rivers, with flood plains and terraces, three ridge moralnes, three till plains, several outwash plains, a number of lacustrine plains, eskers, proglacial sluiceways and muck and peat deposits. The physiographic sketch, Figure 6 , with all of the county's one-square mile sections shown, gives a good idea of the relative size (areal extent) and location of all the land forms. Some elevation polnts on the various landforms provide some idea of general relief throughout the county.

Studying the physlographic sketch from north to south, it can be noted that a small portion of a gently undulating $t 111$ plain is located in the northeastern corner of the county. General surface elevations range between 910 and $930 \mathrm{ft}$.

The next land form to the south is the Mississinewa ridge moraine which is about two and one-half miles wide. Its slope on the north is very gentle and almost imperceptible. On the south, however, where the ridge moralne borders the Mississinewa River, the south slope is somewhat more pronounced. In some places, relief from the flood plain to the crest of the ridge moraine is 40 to $50 \mathrm{ft}$. Crest elevation points along the Mississinewa ridge moralne range from 930 in the west to 970 in the east.

The Mississinewa River enters the county on the eastern border at an elevation of $910 \mathrm{ft}$. and leaves at the northern border at an elevation of $830 \mathrm{ft}$. - an $80-\mathrm{ft}$. drop in about 16 miles. As this part of the river is in the upper reaches, the flood plain is relatively narrow and not deeply incised. Terraces are not well developed, and especially on the south, 
the terraces appear to grade gradually into the uplands. There are no sand dunes along the river.

South of the river is another portion of a large t111 plain. It extends entirely across the county and is six to nine miles wide. It is gently undulating to monotonously flat with several lacustrine plains in 1 ts western third. In its eastern third are a number of eskers and a few kames. Some of the eskers may have had a continuous length of many miles at one time - now the longest segments are about two miles long. Some of the eskers are 30 to $40 \mathrm{ft}$. high and are extensively mined (3). The middle third of the till platn contains several long and well defined, abandoned, glactal sluiceways.

South of the till plain is the very low and narrow Unton City ridge moralne. It is about two miles wide and rises only ten to $20 \mathrm{ft}$. above adjacent plains. Its clayey slopes are extremely gentle and it was very difficult to draw its poorly defined boundary ifmits.

South of the ridge moraine is more of the Tipton Till Plain which contains: the West Fork White Rfver, some large outwash plains, several creeks, several abandoned glacial sluiceways, the Prairie Creek Reservoir, a number of small lake beds and a few eskers and kames.

West Fork White River enters the eastern county boundary at elevation $980 \mathrm{ft}$. and leaves at the western boundary at $870 \mathrm{ft}$. - a drop of about $110 \mathrm{ft}$. In 25 miles. River terraces on the east are small and on the west they blend into a large surrounding outwash plain. Outwash plains bracket streams and old sluiceways in the southern third of the county. 
In the extreme southeastern corner of the county is a portion of the knightstown ridge moraine. It rises to an elevation of $1100 \mathrm{ft}$. Which is about 50 to $60 \mathrm{ft}$. above adjacent outwash plafns and till plains.

\section{ENGINEERING SOIL AREAS}

The soils of Delaware County can be divided into three major groups: (I) glacial or ice-contact soil deposits, (II) fluvial or water-deposited soils, and (III) peat and muck deposits. In the discussion that follows each of the major groups is further subdivided into land form parent material groups. These groups are further subdivided into soil textural groups for which pedological names are also provided. Using the pedological names and Appendices $A, B$ and $C$, engineering properties and problems for all soll areas can be obtained.

\section{GLACIAL DEPOSITED MATERIALS}

The land forms of glacial, or ice-contact deposits in Delaware County include ground moraines, ridge moraines, eskers and kames.

\section{(1) Ridge and Ground Moraine - Clayey Texture}

The ridge and ground moraine parent material of the northern two-thirds of Delaware County is slightly more clayey than the southern one-third. The dividing line between the two different soil types is the southern edge of the Union city ridge moraine. In the east, the dividing line 
follows the West Fork White River to Muncie and then follows the $N$ and $W$ Railroad tracks, slightly northerly, to the western boundary of the county.

The parent material of the northern two-thirds of the county, including the Unton City ridge moraine, the large till plain to the north, the Mississinewa ridge moraine and the very small till plain in the north east corner of the county, is a very clayey soil from former glactal lakes in the northern part of Indiana and ohto.

On the attached engineering solls map, general soll profiles for high and low topographic sites have been drawn and designated profile set No. 1. The soll classification used in all proffles is the one used by the Indiana state Highway Commission.

Parent materials of the northern two-thirds of the county are clays and silty clays and depth to the top of the Chortzon ranges from 20 to $60 \mathrm{in}$. The B-hortzon solls are simflar but usually slightly more plastic. Depth to the top of the B-horizon varies between 8 and $16 \mathrm{in}$. The A-horizon soils are clays, silty clays, silty clay loams and silt loams. Over much of the area loess materials may range to a depth of $18 \mathrm{in}$.

Pedologically the major soils of the area are Blount, Pewamo and Morley (except Morley MvB2 and MrC2). The areas of Blount and Pewamo are about equal while the Morley soils constitute less than ten percent of the area. The Pewamo 
soils are in broad depressions and narrow fingerlike lows within areas of Blount solis which are nearly level or slightly sloping. The Morley soils occupy oval-shaped knolls at slightly higher elevations than Blount and Pewamo soils.

Soil samples of the $A, B$ and C-horizons of each of the three soils, each at two sites, were taken in Delaware county. Samples were taken by the SCS and the Purdue Agricultural Experiment Station and tested in soll laboratories of the Purdue School of Civil Engineering. Location of test sites and the results of laboratory tests are shown in Appendix $A$. Additional test data on the same three soils were taken in other counties and these results are shown in Appendix $B$.

\section{(2) Ridge and Ground Moraine - Clayey to Silty Texture}

The second largest ridge and ground moraine solls area extends from the southern edge of the Union City ridge moraine to the southern boundary of the county. It is a clayey till that is somewhat more silty and sandy and less plastic than the till to the north.

A pedological description of a much larger region, that includes the area in Delaware County, reads as follows:

"The soils are developed in a thin silt mantie less than 18 in. thick and clay loam till that has been leached of carbonates to a variable depth of 18 to 42 in. The unweathered loam till occurs at an average depth of 32 in. It is very compact and ranges from 15 to 30 percent in carbonate of lime. The soils consist of the well dratned Miami, the moderately well drained Celina (not in Delaware County), the somewhat poorly drained Crosby and the poorly drained Bethel silt loams (not in Delaware County) and the very poorly drained Brookston and Kokomo silty clay loams of depressions. Bordering the deeper valleys there are minor areas of the neutral, shallow Hennepin solis on the steep 
slopes. Brookston and Crosby solls commonly known as "Black and $\mathrm{Cl}$ ay land" are the dominant soils of this region. Crosby silt loam, the more extensive soil, occurs on flat to gentiy undulating areas intermingled with dark colored Brookston silty clay loam of the depressions. Crosby has a grayish brown sllt loam surface soll 8 to $10 \mathrm{in}$. thick that overlies a gray clay loam subsoll mottled with yellowish brown to a depth of about $30 \mathrm{in}$. Near the contact with the limy till, at average depth of 33 inches, there is a dark mottled yellowlsh brown neutral clay loam layer. The clay content of the subsoli ranges from 30 to 40 percent and averages about 34 percent...one principal problem is maintaining drainage for crops on the level and depressed areas" (9).

On the attached engineering solls map, general soll profiles for topographic highs and lows in the area have been designated as soll profile set No. 2. The proflles show that the parent material may be either clay, clay loam or loam and top of the C-horizon may range from about $2 \mathrm{ft}$. to $6 \mathrm{ft}$. The B-horizon is either clay or silty clay and its contact with the A-horizon ranges from $8 \mathrm{in.}$ to $24 \mathrm{in}$. The A-horizon may be efther clay, silty clay, silty clay loam or silt loam.

On undulating ground moraine and ridge moraine, the Miami soils (except $M n A, M n B$, and $M n C 2$ - Appendices $B$ and C) are on the slight knolls. Crosby soils (CrA) are intermediate between the Miami and Brookston soils ( $B r$ ) in the low areas. Brookston silty clay loam, stony subsolls (Bs), are found in narrow glacial sluiceways as well as kokomo silty clay loam, stratified substratum (Ko), and Kokomo mucky silt loam, stratified substratum $(\mathrm{Km})$. The latter three solls are discussed in more detail in following pages of the report. 
(3) Eskers and Kames

In the central eastern and southeastern part of the county there are numerous eskers and kames. These land forms are outlined with dashed lines on the soils map - the elongated forms are eskers and the more rounded forms are kames or clusters of small kames. Many of the eskers and kames are being mined for sand and gravel. The four largest sand and gravel pits are located on eskers. In one or two of the pits, limestone is found below the sand and gravel and 1 imestone is quarried for crushed stone.

The sand and gravel parent material classifies as silty poorly graded gravel and/or silty poorly graded sand which is stratified and cross bedded. Overburden may be as shallow as $20 \mathrm{in}$. On the crests and as deep as $10 \mathrm{ft}$. On the lower sides of the eskers and kames.

The soils most commonly found on eskers and kames include the: Fox (FoC2, FoD2) and the Morley, gravelly substratum (MuC3, MuD2, MvB2, MvC2, MwC3). Qualitative solils data for these soils is provided in Appendix $B$ and profile No. 3, on the soils map, graphically shows the soil horizon depths and textures.

\section{FLUVIAL DEPOSITED MATERIALS}

The fluvial deposited soils in Delaware County are grouped and tabulated below according to their land form and parent material texture: 
Outwash Plains, Terraces and Valley Trains

Sandy and Gravelly

Sandy and S1lty

Narrow Valley Trains (Glacial Sluiceways)

Gravelly Loam

Fine sand and silt

Clayey

Lacustrine Plains

Clayey

Fine Sand and Silt

Recent Alluvium

silty and Sandy

(1) Outwash Plains - Sand and Gravel Texture

All the outwash plains are located in the southern onethird of the county mainly bordering rivers, streams and abandoned glacial sluiceways. The largest outwash plain areas are immediately west and southwest of Muncie along both sides of West Fork White River and Buck Creek. Another outwash plain area is located south and east of Muncie along Prairie Creek Reservoir and along Buck Creek.

Some river and stream terraces, especially along the western part of West Fork White River, were relatively small and indistinct topographically and thus they were mapped as parts of the larger outwash plains. 
On the soils map the outwash material is represented by soil profile.No. 4. The profile shows that depths to a parent material of stratified sand and gravel may range from $20 \mathrm{in.}$ to $120 \mathrm{in}$. From bridge borings on SR 67 bypass, it appears that outwash in this area is essentially all sand. There are indications that parent materials may be shallower and more gravelly closer to the streams. Depth to the top of the B-horizon generally ranges from 8 in to $13 \mathrm{in}$. and the soil may be a gravelly clay, loam, silty clay, or a clay loam. The A horizon may be either gravelly clay, loam, silt loam or a silty clay loam.

Pedologically the soils may be Fox (FsA, FsB, FoC2, FoC3, $\mathrm{F} \times \mathrm{BB}$ or $\mathrm{F} \times(3)$, or Ockley (OCA or $\mathrm{OCB})$, or Miami, gravelly substratum (MmA, MmA, MnB or $M n C 2$ ). The Miami soils constitute the great majority of the area, especially away from the streams, and are probably much more sandy than gravel1y.

\section{(2) Outwash Plains - Sand and silt Texture}

East of Muncie, within the large southern loop of the West Fork White River is an outwash area of stratified sand and s1lt. There are numerous other areas of stratified sand and sflt in the outwash plains but most are too small to show on the map. The parent material, sometimes with a little gravel, is 40 to $55 \mathrm{in}$. deep and overlying $A$ - and B-horizon materials ranges from clay to sandy loam - see profile No. 5 on the map. 
Pedologically the soils belong to the Martinsville series, MeA, MeB and MdC2.

(3) Terraces and Valley Trains - Sand and Gravel Texture

Terrace and valley train sand and gravel deposits in Delaware County are relatively small. These deposits are found mainly along the Mississinewa River, West Fork White River, Killbuck Creek and Mud Creek.

Depth to sand and gravel parent material generally ranges between $20 \mathrm{in}$. and $65 \mathrm{in}$. and the $\mathrm{B}$-horizon is down about $8 \mathrm{in}$. to $11 \mathrm{in.}$ - see soll proftle No. 6 on the map. The B-horizon material is either clay, gravelly clay or silty clay. The A-horizon is either gravelly clay, silty clay loam or silt loam.

Pedologically the solls are Fox (FsA, FsB, FoC2, Fod2, $F \times B 3$ and $F \times C 3)$ and $O C k l e y(O C A$ and $O C B)$.

(4) Terraces and Valley Trains - Gravelly silt Loam Texture

All along the Mississinewa River there are a number of terraces and valley train deposits that have primarily a gravelly silt loam parent material. On the solls maps the soil profile is shown by soil profile No. 7.

Parent material is found at a depth of $28 \mathrm{in}$. to $72 \mathrm{in}$. and it may be either a: gravelly silty clay loam, gravelly silt loam, gravelly sandy loam or possibly stratified sand and gravel. The B-horizon, at a depth of $7 \mathrm{in}$. to $15 \mathrm{in}$. may be either a: gravelly silt loam, gravelly clay loam, silty clay loam or clay. The A-horizon may be a: silt loam, silty clay loam, gravelly clay loam or clay. 
Pedologically the soils are crosby silt loam, stony subsoil (CSA), or Brookston silty clay loam, stony subsoil (Bs).

\section{(5) Alluvial Plains}

The two largest alluvial plain areas (bounded by sawteeth on the map) are along the two major rivers - the Mississinewa and West Fork White River. They are also found along Killbuck Creek. Buck Creek and Campbell Creek. Annual flooding should be anticipated within the sawtooth areas.

Parent material, at a depth of $26 \mathrm{in.}$ to $50 \mathrm{in.}$, is primarily silty and loamy but in a few places there may be stratified sand and gravel or loamy sand. Most material however is loam, silt loam, sandy loam and clay loam. The coarser parent material is generally in the topographic high nearer the streams - see profile set No. 8 on the map. The A- and B-horizons are mostly silt loams and clay loams and frequently the $B$-horizon is absent or not discernable.

Soil in the topographic highs are Genessee (Ge) Ross (Ro) and the lower level solls are shoals (Sh) and Sloan (Sn).

\section{(6) Lacustrine Plains - Clayey Texture}

In the northwest corner of the county there are five clayey lacustrine plains. The three larger ones also contain peat and muck deposits. The land forms of the former lakes is not well defined - the lakes were probably more like shallow slack water basins. 
The parent material of stratified clay, silty clay, silty clay loam and silt loam is at a depth of $42 \mathrm{in.} \mathrm{to}$ $78 \mathrm{in}$. The top of the B-horizon is $10 \mathrm{in}$. to $15 \mathrm{ln}$. deep and is usually clay and the A-horizon is clay or silty clay see soil profile No. 9. The primary soil series is the Pewamo silty $\mathrm{clay}$ loam, stratified substratum (Pf).

(7) Lacustrine Plains - Silty and Sandy Texture

In the southern two-thirds of the county there are a number of widely scattered lacustrine plains measuring just larger and smaller than about one square mile in area.

These particular lacustrine plains have a stratifled sandy and silty parent material at a depth of about $42 \mathrm{in}$. to $60 \mathrm{in.}$ Reportediy, in a few places, there are some commerctal sand and gravel deposits under the lake deposited soils. The $A-$ and B-horizons are primarily clays.

The soil series involved is the Rensselaer (RC), and the profile is No. 10 on the map.

(8) Narrow Valley Trains - Glacial Sluiceways
Textures - (1) Fine Sand and Silt, (2) Gravelly Loame
and (3) Clayey

Most of the narrow valley trains, that formerly were glacial sluiceways, have a C-horizon of stratified fine sands and silts at a depth of $30 \mathrm{in.}$ to $84 \mathrm{in}$. At some places sand and gravel is found below at depth of $5 \mathrm{ft}$. to $7 \mathrm{ft}$. The overlying soils are clays and silty clays with up to $10 \mathrm{in}$. of surface muck in some places. The sand and silty sluiceways are represented by soil profile No. 11. Pedologically the solls are mainly Rensselaer (RC) with lesser Kokomo silty 
clay loam, stratified substratum, (Ko), and even lesser Kokomo mucky silt loam, stratified substratum, $(\mathrm{Km})$.

other slufceways, represented by profile No. 12 have a gravelly loam, gravelly sandy loam and gravelly silt loam $\mathrm{C}$-horizon at $30 \mathrm{in.}$ to $60 \mathrm{in}$. The $\mathrm{A}$ - and $B$-horizons are mainly clays. The $B$ has some gravel and stones. The soil series is Brookston silty clay loam, stony subsoil (Bs).

A very few of the sluiceways are clayey and are represented by profile No. 13. The parent material, at $42 \mathrm{in.} \mathrm{to} 78 \mathrm{in}$. are stratified clays, silty clays, silty clay loams and silt loams. The soil series is Pewamo silty clay loam, stratified substratum, (Pf).

\section{PEAT AND MUCK DEPOSITS}

The so-called peat and muck deposits, shown as solid black on the map, range from only slightly or partially decomposed vegetable matter, usually with some mineral material, to possible commercial type deposits of peat. Only insignificant deposits of marl have been reported in the county. Some mapped areas will have as much as 17 in. of silt loam at the surface over the unstable peat and/or muck materials - see the Wallkill (Wa) soll series described in the Appendices. Other soils include the Carlisle ( $\mathrm{Ca}$ ) and the Linwood $(\operatorname{Ln})$.

The larger deposits are found in the northwestern quadrant of the county with lesser amounts in the southwest and southeast. Many of the deposits are known to be at least $5 \mathrm{ft}$. deep. 


\section{BIBLIOGRAPHY}

1. Burger, A. M., Forsyth, J. L., Nicoll, R. S. and Wayne, W. J., "Geologic Map of the $1^{\circ} \times 2^{\circ}$ Muncie Quadrangle, Indiana and Ohio, Showing Bedrock and Unconsolidated Deposits", Department of Natural Resources, 1971.

2. Carr, D. D. and French, R. R., "Directory of Crushed Stone, Ground Limestone, and Cement Producers in Indiana", Indiana Geological Survey, May 1968.

3. Carr. D. D. and Webb, W. M., "Directory of Sand and Gravel Producers in Indiana", Indiana Geological Survey, 1968.

4. Hittle, J. E., "Population Trends for Indiana Counties, Citles and Towns 1960-1970, Highway Extension and Research Project for Indiana Counties, Purdue University.

5. Huffman, K. K., et. al., "Soll Survey of Delaware County, Indiana, Soil Conservation Service, U. S. Department of Agriculture in Cooperation with Purdue University Agricultural Experiment Station, July, 1972.

6. Pensak, A. P., and Shaver, R. H., "The Silurian Formations of Northern Indiana", Indiana Department of Conservation. Geological Survey Builetin 32, 1964.

7. Taylor, E. A., "The Roads and Road Materials of Portions of Central and Eastern Indiana", (Delaware County - page 459), 30th Annual Report, Indlana Department of Geology and Natural Resources, 1905.

8. Thornbury, W. D., and Deane, H. L., "The Geology of Miami County, Indiana, Indiana Department of Conservation, Geological Survey Bulletin No. $8,1955$.

9. Wayne, W. J., "Ice and Land - A Revtew of the Tertiary and Pieistocene History of Indiana", reprint from "Natural Features of Indiana", Indiana Academy of Science, State Library, Indianapolis, Indiana, 1966.

10. Wayne, W. J., "The Crawfordsville and Knightstown Moraines in Indiana", Indiana Department of Conservation Geological Survey Report of Progress 28, Bloomington, Indiana, 1965.

11. Wayne, W. J., "Thickness of Drift and Bedrock Physiography of Indiana North of the Wisconsin Glacial Boundary", Indiana Department of Conservation, Geological Survey Report of Progress 7, 1956.

12. Wayne, W. J. and Thornbury, W. D., "Glacial Geology of Wabash County, Indiana", Indiana Department of Conservation, Geological Survey Bulletin No. 5, 1951. 
13. Yeh, P. T., "Drainage Map of Delaware County," Joint Highway Research Project, Purdue Untversity, 1954.

14. "Climatological Summary", U. S. Department of Commerce Environmental Science Administration in Cooperation with Muncie Chamber of Commerce Climatography of the United States No. 20-12, Station - Muncie, Indiana, 1967.

15. Indiana State Highway Commission Boring Logs and Sol1 Test Data for S.R. 67 Bypass Around Muncie, 1965.
$F-892$
(1) P.E. F-892(3) Const.
F-892 (1) P.E. F-892(5) Const.
F-892 (1) 
TAB LE 5.- Enginecrin!!

[Tcsts perfolmed by Purdue University in cooperation with Iudiana State Highway Departuncnt and U.S. Departucnt of Conuncrer,

\begin{tabular}{|c|c|c|c|c|c|c|}
\hline \multirow{3}{*}{ Soil name and location 1} & \multirow{3}{*}{ Depth } & \multicolumn{2}{|c|}{ Moisture-density data ${ }^{2}$} & \multirow{2}{*}{\multicolumn{3}{|c|}{ Mechanical analysis ${ }^{3}$}} \\
\hline & & \multirow{2}{*}{$\begin{array}{c}\text { Maximum } \\
\text { dry } \\
\text { density }\end{array}$} & \multirow{2}{*}{$\begin{array}{c}\text { Optimum } \\
\text { moisture }\end{array}$} & & & \\
\hline & & & & $\%$-in. & $7_{8}^{\prime}$-in. & $\begin{array}{l}\text { No. } 4 \\
(4.7 \mathrm{~mm} .)\end{array}$ \\
\hline $\begin{array}{l}\text { Blount silt loam: } \\
\text { NE1/4W1/4 sec. 9, T. } 22 \text { N., R. } 11 \text { E. (Finer textured C } \\
\text { horizon than modal.) }\end{array}$ & $\begin{array}{l}\text { Inches } \\
0-6 \\
19-32 \\
32-44\end{array}$ & $\begin{array}{r}\text { Lb./cu. } \text { th }_{98} \\
98 \\
104\end{array}$ & $\begin{array}{r}\text { Percent } \\
22 \\
23 \\
19\end{array}$ & 100 & & $\begin{array}{r}100 \\
100 \\
98\end{array}$ \\
\hline NE $1 / 4$ SEy sec. 8, T. 22 N., R. 10 E. (Modal.) ........... & $\begin{array}{l}0-7 \\
18-27 \\
27-33\end{array}$ & $\begin{array}{r}96 \\
99 \\
106\end{array}$ & $\begin{array}{l}23 \\
22 \\
18\end{array}$ & 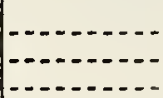 & & 100 \\
\hline $\begin{array}{l}\text { Morley silt loam: } \\
\text { NE⿺辶 NW } 1 / 4 \text { scc. } 9 \text {, T. } 22 \text { N., R. } 11 \text { R. (Finer textured } \\
\text { and thinner A horizon than modal.) }\end{array}$ & $\begin{array}{l}0-5 \\
10-20 \\
29-34\end{array}$ & $\begin{array}{r}94 \\
99 \\
117\end{array}$ & $\begin{array}{l}24 \\
22 \\
14\end{array}$ & 100 & $\begin{array}{r}100 \\
100 \\
97\end{array}$ & $\begin{array}{l}99 \\
99 \\
95\end{array}$ \\
\hline NW1/4SW1/4 sec. 9, T. 22 N., R. 10 E. (Mlodal.) ........ & $\begin{array}{l}0-7 \\
14-21 \\
21-31\end{array}$ & $\begin{array}{r}99 \\
99 \\
119\end{array}$ & $\begin{array}{l}22 \\
22 \\
15\end{array}$ & 100 & $\begin{array}{r}100 \\
100 \\
00\end{array}$ & $\begin{array}{l}99 \\
99 \\
95\end{array}$ \\
\hline $\begin{array}{l}\text { Pewamo silty clay loam: } \\
\text { NW } 1 / 4 \text { NW } 1 / 4 \text { sec. } 9, \text { T. } 22 \text { N., R. } 11 \text { E. (Coarser textured } \\
\text { B horizon than modal.) }\end{array}$ & $\begin{array}{l}13-24 \\
24-34 \\
47-78\end{array}$ & $\begin{array}{l}101 \\
103 \\
113\end{array}$ & $\begin{array}{l}21 \\
19 \\
12\end{array}$ & 100 & - & $\begin{array}{r}100 \\
100 \\
98\end{array}$ \\
\hline NW $3 / 4$ SW 144 sec. 9, T. 22 N., R. 10 E. (Modal.) ........... & $\begin{array}{c}0-6 \\
10-34 \\
45-56\end{array}$ & $\begin{array}{r}94 \\
111 \\
114\end{array}$ & $\begin{array}{l}25 \\
16 \\
13\end{array}$ & 100 & $\begin{array}{r}100 \\
98\end{array}$ & $\begin{array}{r}100 \\
99 \\
94\end{array}$ \\
\hline
\end{tabular}

1 Parent material of the tested soils is calcareous till of Wisconsin age.

2 Based on AASHIO Designation 'T 99-57, Methods A and D (1).

3 Mechanical analyses according to the AASHO Designation T 88-57(1). Results by this procedure may differ somewhat from results obtained by the soil survey proccdure of the Soil Conservation Service (SCS). In the AASHO procedure, the fine material is analyzed by the hydrometer method and the various grain-size fractions are calculated on the basis of all the material, including that coarser than 2 
TABLE 6.- Estimatod cu!neQrin!

Lit incluled in this table beease their eluracteristics are too variable to be classified, are the land types Borrow pits (Bp), Gravel pits not be applic:able.

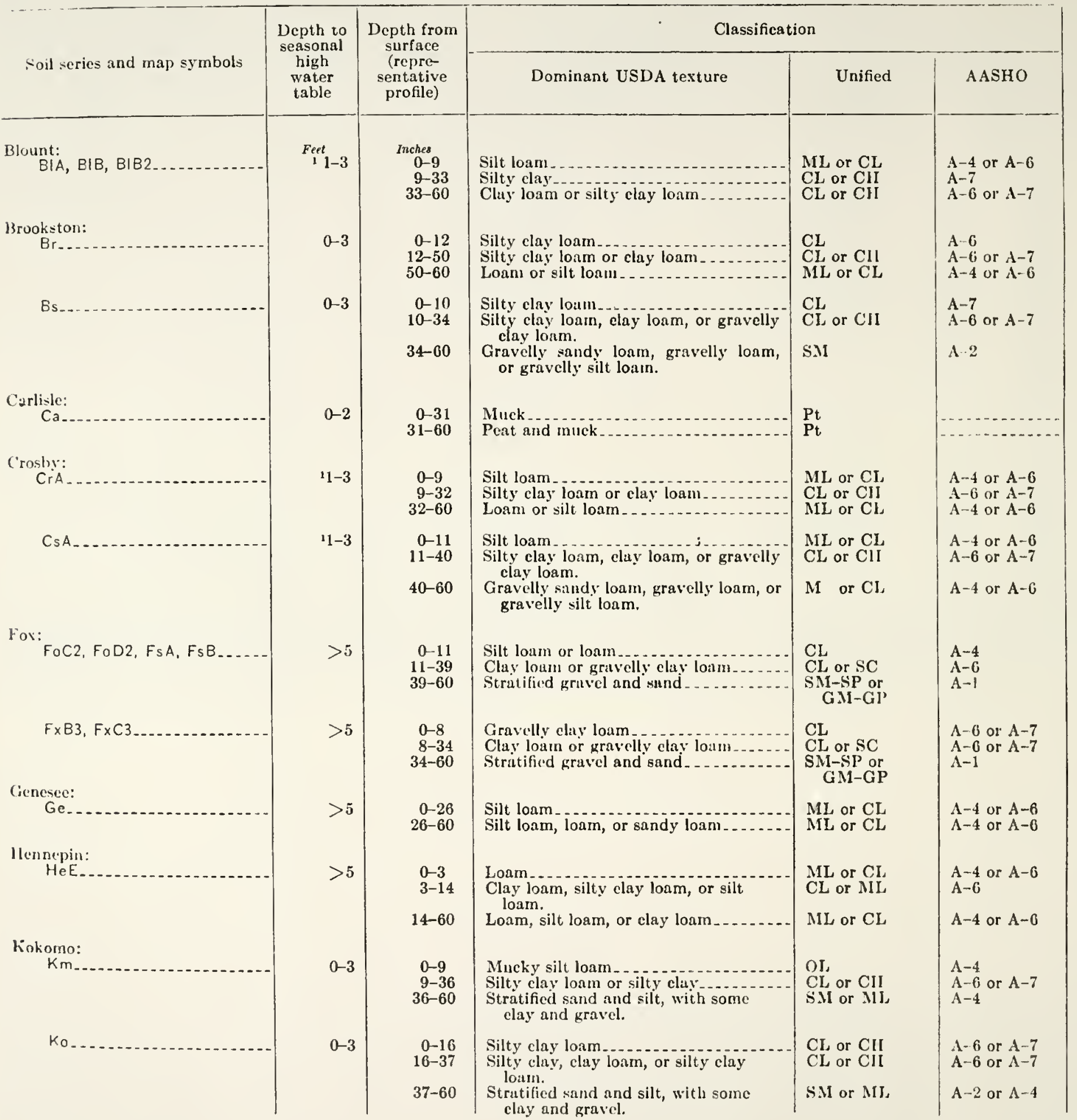


mperties of the soils

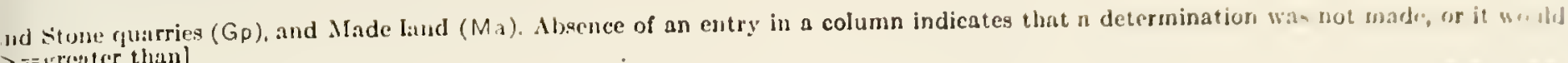
$==$ graterter than]

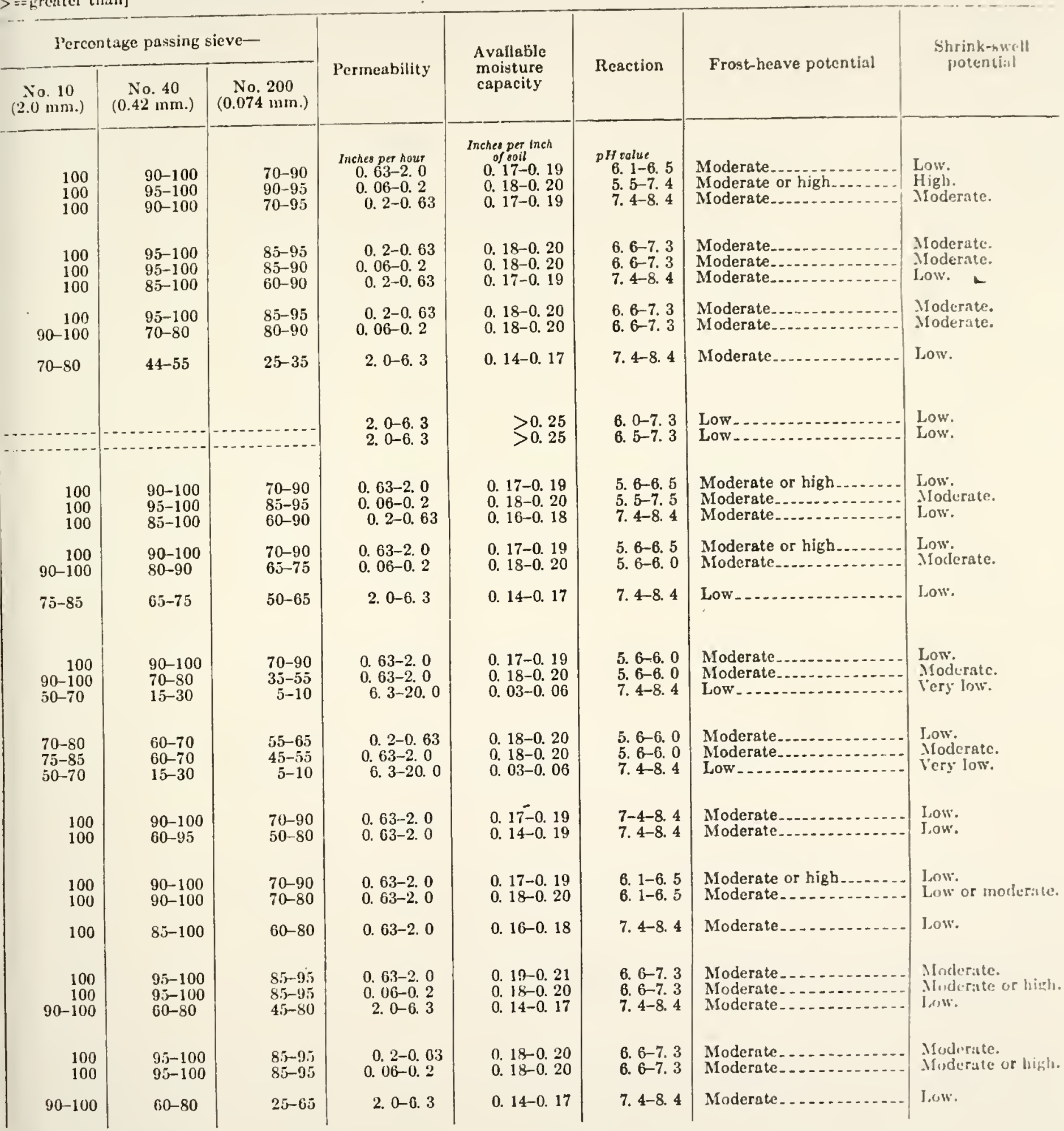


TABLE: 6.---fistimated + "uginrerin!

\begin{tabular}{|c|c|c|c|c|c|}
\hline \multirow{2}{*}{ Soil series and unap symbols } & \multirow{2}{*}{$\begin{array}{l}\text { Depulh to } \\
\text { scasonal } \\
\text { liigh } \\
\text { water } \\
\text { table }\end{array}$} & \multirow{2}{*}{$\begin{array}{l}\text { Depth from } \\
\text { surface } \\
\text { (repre- } \\
\text { sentativc } \\
\text { profile) }\end{array}$} & \multicolumn{3}{|c|}{ Clitssification } \\
\hline & & & Dominant USDA texture & Unified & AASIIO \\
\hline $\begin{array}{l}\text { Linwood: } \\
\text { Lm.- }\end{array}$ & $\begin{array}{l}\text { Feet } \\
\quad 0-2\end{array}$ & $\begin{array}{r}\text { Inches } \\
0^{-26} \\
26-60\end{array}$ & $\begin{array}{l}\text { Muck } \\
\text { Silt loam, loam, or sandy loam.. }\end{array}$ & $\begin{array}{l}\mathrm{Pt} \\
\mathrm{ML} \text { or } \mathrm{CI}\end{array}$ & $A-4$ or $A-6$ \\
\hline $\begin{array}{l}\text { Martinsville: } \\
\qquad \mathrm{MdC2} .\end{array}$ & $>5$ & $\begin{array}{r}0-11 \\
11-47\end{array}$ & $\begin{array}{l}\text { Sandy loam } \\
\text { Clay loam, sandy clay loit } \\
\text { sandy loam. or }\end{array}$ & $\begin{array}{l}\mathrm{SMI} \\
\mathrm{CL} \text { or } \mathrm{SC}\end{array}$ & $\begin{array}{l}\Lambda-4 \text { or } A-2 \\
\Lambda-6\end{array}$ \\
\hline & & $47-60$ & $\begin{array}{l}\text { Stratified sand and silt with some } \\
\text { gravel. }\end{array}$ & SMISIP & $A-2$ \\
\hline MeA, MeB $\ldots$ & $>5$ & $\begin{array}{r}0-10 \\
10-43\end{array}$ & $\begin{array}{l}\text { Loam } \\
\text { Silty clay loam, clay loan, or sandy } \\
\text { clay loam. }\end{array}$ & $\begin{array}{l}\text { ML or CL } \\
\text { CL or CHI }\end{array}$ & $\begin{array}{l}A-4 \text { or } A-6 \\
A-6 \text { or } A-7\end{array}$ \\
\hline & & $43-60$ & Stratified sand and silt with some gravel. & $S P-S M$ & $\Lambda-2$ \\
\hline $\begin{array}{l}\text { Miami: } \\
\qquad \begin{array}{l}M m A_{1} M m B 2, M m C 2 \\
M m D\end{array}\end{array}$ & $>5$ & $\begin{array}{r}0-12 \\
12-36 \\
36-60\end{array}$ & $\begin{array}{l}\text { Silt loam } \\
\text { Clay loam or silty clay loam or silt loam } \\
\text { Loam }\end{array}$ & $\begin{array}{l}\text { ML or CL } \\
\text { CI or Cll } \\
\text { IIL or CL }\end{array}$ & $\begin{array}{l}\Lambda-1 \text { or } \Lambda-6 \\
\Lambda-6 \text { or } \Lambda-7 \\
A-4 \text { or } A-6\end{array}$ \\
\hline $\mathrm{MnA}, \mathrm{MnB}, \mathrm{MnC} 2 \ldots$ & $>5$ & $\begin{array}{l}0-12 \\
12-40 \\
40-50 \\
50-120\end{array}$ & $\begin{array}{l}\text { Silt loam } \\
\text { Silty clay loaul or clay loam } \\
\text { Loam or silt loam } \\
\text { Stratified gravel and sand }\end{array}$ & 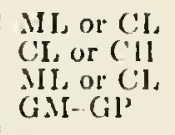 & $\begin{array}{l}\Lambda-4 \text { or } \Lambda-6 \\
\Lambda-6 \text { or } \Lambda-7 \\
\Lambda-1 \\
\Lambda-1\end{array}$ \\
\hline MoA, MoB..... & $>5$ & $\begin{array}{r}0-10 \\
10-40 \\
40-60\end{array}$ & $\begin{array}{l}\text { Silt loam } \\
\text { Clay loam } \\
\text { Clay loam or silty clay loam }\end{array}$ & $\begin{array}{l}\text { MI, or } \mathrm{CI} \\
\mathrm{CI} \text { or } \mathrm{SC} \\
\mathrm{CH} \text { or CII }\end{array}$ & $\begin{array}{l}A-4 \text { or } \Lambda-6 \\
\Lambda-6 \text { or } \Lambda-4 \\
\Lambda-6 \text { or } \Lambda-7\end{array}$ \\
\hline $\mathrm{MrB3}, \mathrm{MrC3}$ & $>5$ & $\begin{array}{c}0-8 \\
8-34 \\
34-60\end{array}$ & $\begin{array}{l}\text { Clay loanı or silty clay loam } \\
\text { Clay loam or silty clay loam } \\
\text { Loam or silt loan }\end{array}$ & $\begin{array}{l}\text { CL or CIH } \\
\text { CL or Cll } \\
\text { ML or CI. }\end{array}$ & $\begin{array}{l}A-6 \text { or } A-7 \\
A-1 ; \text { or } A-7 \\
A-4 \text { or } A-6\end{array}$ \\
\hline $\begin{array}{l}\text { Morley: } \\
\text { MuB, MuB2, MuD2 _. }\end{array}$ & $>5$ & $\begin{array}{c}0-7 \\
7-25 \\
25-60\end{array}$ & $\begin{array}{l}\text { Silt loam } \\
\text { Silty clay or silty clay loam } \\
\text { Clay loam or silty clay loam.... }\end{array}$ & $\begin{array}{l}M L \text { or } \mathrm{Cl} \\
\mathrm{CL} \text { or } \mathrm{Cll} \\
\mathrm{CL} \text { or } \mathrm{CHI}\end{array}$ & $\begin{array}{l}A-4 \text { or } A-6 \\
A-7 \\
A-6\end{array}$ \\
\hline $\mathrm{M} v 82, \mathrm{M} \vee C 2 \ldots$ & $>5$ & $\begin{array}{l}0-8 \\
8-26 \\
26-48 \\
48-120\end{array}$ & $\begin{array}{l}\text { Silt loam } \\
\text { Silty clay or silty clay loam } \\
\text { Clay loam or silty clay loam } \\
\text { Stratified gravel and sand }\end{array}$ & $\begin{array}{l}\text { ML or CI } \\
\text { CI, or CII } \\
C I \text { or CII } \\
\text { GP-GII }\end{array}$ & $\begin{array}{l}A-4 \text { or } A-6 \\
A-7 \\
A-6 \\
A-1\end{array}$ \\
\hline MwB3, MwC3 .... & $>5$ & $\begin{array}{c}0-6 \\
6-22 \\
22-60\end{array}$ & $\begin{array}{l}\text { Silty clay loam } \\
\text { Silty clay or silty clay loam } \\
\text { Clay loam or silty clay loam }\end{array}$ & $\begin{array}{l}\text { CL or CII } \\
\text { CI or CII } \\
\text { CL or Cil }\end{array}$ & $\begin{array}{l}A-6 \text { or } \Lambda-7 \\
A-7 \\
A-6 \text { or } A-7\end{array}$ \\
\hline $\begin{array}{l}\text { Ockley: } \\
\text { OçA, OcB... }\end{array}$ & $>5$ & $\begin{array}{r}0-10 \\
10-49 \\
49-60\end{array}$ & 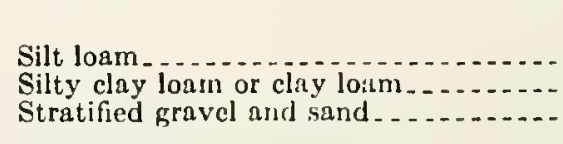 & 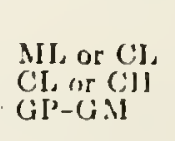 & $\begin{array}{l}A-4 \text { or } A-6 \\
\Lambda-t ; \text { or } A-7 \\
A-1\end{array}$ \\
\hline $\begin{array}{l}\text { Pewamo: } \\
\text { Pe, Pk } \\
\text { (For properties of } \\
\text { J3rookston soils in } \\
\text { mapping unit Pk, see } \\
\text { Brookston series in this } \\
\text { table.) }\end{array}$ & $0-3$ & $\begin{array}{r}0-12 \\
12-45 \\
45-60\end{array}$ & $\begin{array}{l}\text { Silty clay loam or silt loam } \\
\text { Silty clay } \\
\text { Clay loam or silty clay loam }\end{array}$ & $\begin{array}{l}\text { CL or CII } \\
\text { CL, or CHI } \\
\text { CL }\end{array}$ & 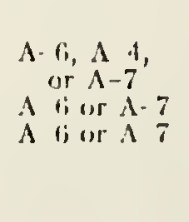 \\
\hline Pf..... & $0-3$ & $\begin{array}{r}0-10 \\
10-42 \\
42-60\end{array}$ & $\begin{array}{l}\text { Silty clay loam } \\
\text { Silty clay loam } \\
\text { Silt loam or silty clay loam }\end{array}$ & $\begin{array}{l}\text { CL or } C H I \\
\text { CL or CII } \\
\text { CL or MII }\end{array}$ & $\begin{array}{l}A \cdot \text { for } A-7 \\
\hat{A}-\bar{i} \text { or } A-1\end{array}$ \\
\hline & $0-3$ & $\begin{array}{r}0-12 \\
12-41 \\
41-60\end{array}$ & $\begin{array}{l}\text { Silty clay lonm } \\
\text { Silty clay loan or clay lonm } \\
\text { Stratified sand and silt }\end{array}$ & $\begin{array}{l}\text { CL or ClI } \\
\text { CI or CII } \\
\text { SiI }\end{array}$ & $\begin{array}{l}A-6 \text { or } A-7 \\
A-7 \\
A-2\end{array}$ \\
\hline
\end{tabular}


properties of the soils-Continued

\begin{tabular}{|c|c|c|c|c|c|c|c|}
\hline \multicolumn{3}{|c|}{ Percentage passing sieve- } & \multirow{2}{*}{ Permeability } & \multirow{2}{*}{$\begin{array}{l}\text { Available } \\
\text { moisture } \\
\text { eapacity }\end{array}$} & \multirow{2}{*}{ Reaction } & \multirow{2}{*}{ Frost-heave potential } & \multirow{2}{*}{$\begin{array}{l}\text { Shriuk-nucl] } \\
\text { potential }\end{array}$} \\
\hline $\begin{array}{l}\text { No. } 10 \\
(2.0 \mathrm{~mm} .)\end{array}$ & $\begin{array}{c}\text { No. } 40 \\
(0.42 \mathrm{~mm} .)\end{array}$ & $\begin{array}{c}\text { No. } 200 \\
(0.074 \mathrm{~mm} .)\end{array}$ & & & & & \\
\hline 100 & $85-100$ & $60-90$ & $\begin{array}{r}\text { Inches per hour } \\
2.0-6.3 \\
0.63-2.0\end{array}$ & $\begin{array}{l}\text { Inches per inch } \\
\text { of soill } \\
\rightarrow 0.25 \\
0.17-0.19\end{array}$ & $\begin{array}{l}\text { pH value } \\
5.6-6.5 \\
7.4-8.4\end{array}$ & Low & $\begin{array}{l}\text { Lor: } \\
\text { Low. }\end{array}$ \\
\hline $\begin{array}{l}100 \\
100\end{array}$ & $\begin{array}{l}60-70 \\
60-90\end{array}$ & $\begin{array}{l}30-40 \\
35-55\end{array}$ & $\begin{array}{l}0.63-2.0 \\
0.63-2.0\end{array}$ & $\begin{array}{l}0.13-0.15 \\
0.18-0.20\end{array}$ & $\begin{array}{l}\text { 5. 6-6. } \\
5.6-6.0\end{array}$ & $\begin{array}{l}\text { Moderate. } \\
\text { Moderate. }\end{array}$ & $\begin{array}{l}\text { Lon. } \\
\text { Moderate or lок. }\end{array}$ \\
\hline $90-100$ & $50-70$ & $5-12$ & 6. $3-20.0$ & $0.11-0.15$ & 7. $4-8.4$ & Low . . . & Low. \\
\hline $\begin{array}{l}100 \\
100\end{array}$ & $\begin{array}{l}90-100 \\
90-100\end{array}$ & $\begin{array}{l}70-90 \\
70-90\end{array}$ & $\begin{array}{l}0.63-2.0 \\
0.63-2.0\end{array}$ & $\begin{array}{l}0.17-0.19 \\
0.18-0.20\end{array}$ & $\begin{array}{l}\text { 5. } 6-6.5 \\
\text { 5. } 0-7.3\end{array}$ & $\begin{array}{l}\text { Moderate or high... } \\
\text { Moderate... }\end{array}$ & $\begin{array}{l}\text { Low. } \\
\text { Moderate. }\end{array}$ \\
\hline $90-100$ & $50-70$ & $5-12$ & 2. $0-6.3$ & $0.11-0.15$ & 7. $4-8.4$ & Low & L.ок: \\
\hline $\begin{array}{l}100 \\
100 \\
100\end{array}$ & $\begin{array}{l}90-100 \\
90-100 \\
85-95\end{array}$ & $\begin{array}{l}70-90 \\
70-80 \\
60-75\end{array}$ & $\begin{array}{l}0.63-2.0 \\
0.63-2.0 \\
0.63-2.0\end{array}$ & $\begin{array}{l}0.17-0.19 \\
0.18-0.20 \\
0.16-0.18\end{array}$ & $\begin{array}{l}\text { 6. } 1-6.5 \\
\text { 5. } 6-6.0 \\
7.4-8.4\end{array}$ & $\begin{array}{l}\text { Moderate or high.... } \\
\text { Moderate } \\
\text { Moderate......... }\end{array}$ & $\begin{array}{l}\text { Low. } \\
\text { Moderate. } \\
\text { Low. }\end{array}$ \\
\hline $\begin{array}{r}100 \\
100 \\
100 \\
35-45\end{array}$ & $\begin{array}{l}90-100 \\
90-100 \\
85-95 \\
20-30\end{array}$ & $\begin{array}{r}70-90 \\
70-80 \\
60-75 \\
5-15\end{array}$ & $\begin{array}{l}0.63-2.0 \\
0.63-2.0 \\
0.63-2.0 \\
6.3-20.0\end{array}$ & $\begin{array}{l}0.17-0.19 \\
0.18-0.20 \\
0.16-0.18 \\
0.03-0.05\end{array}$ & $\begin{array}{l}\text { B. } 1-\text { - } .5 \\
\text { 5. } 6-6.0 \\
\text { 7. } 4-7.8 \\
\text { 7. } 4-8.4\end{array}$ & $\begin{array}{l}\text { Moderate or high } \\
\text { Moderate... } \\
\text { Moderate. } \\
\text { Low }\end{array}$ & $\begin{array}{l}\text { Iow: } \\
\text { Moderate. } \\
\text { Low. } \\
\text { Very low. }\end{array}$ \\
\hline $\begin{array}{r}100 \\
95-100 \\
100\end{array}$ & $\begin{array}{l}90-100 \\
70-80 \\
90-100\end{array}$ & $\begin{array}{l}70-90 \\
35-55 \\
70-80\end{array}$ & $\begin{array}{l}0.63-2.0 \\
0.63-2.0 \\
0.63-2.0\end{array}$ & $\begin{array}{l}0.17-0.19 \\
0.18-0.20 \\
0.17-0.19\end{array}$ & $\begin{array}{l}\text { 6. } 1-6.5 \\
\text { 5. } 6-6.0 \\
\text { 7. } 4-8.4\end{array}$ & $\begin{array}{l}\text { Moderate or hlgh. } \\
\text { Moderate. } \\
\text { Moderate... }\end{array}$ & $\begin{array}{l}\text { Lon: } \\
\text { Moderate. } \\
\text { Moderate. }\end{array}$ \\
\hline $\begin{array}{l}100 \\
100 \\
100\end{array}$ & $\begin{array}{l}90-100 \\
90-100 \\
85-95\end{array}$ & $\begin{array}{l}70-80 \\
70-80 \\
60-75\end{array}$ & $\begin{array}{l}0.2-0.63 \\
0.63-2.0 \\
0.63-2.0\end{array}$ & $\begin{array}{l}0.18-0.20 \\
0.18-0.20 \\
0.16-0.18\end{array}$ & $\begin{array}{l}\text { 5. } 6-6.0 \\
5.6-6.0 \\
\text { 7. } 4-8.4\end{array}$ & $\begin{array}{l}\text { Moderate or high.. } \\
\text { Moderate....... } \\
\text { Moderate........ }\end{array}$ & $\begin{array}{l}\text { Moderate. } \\
\text { Moderate. } \\
\text { Low. }\end{array}$ \\
\hline $\begin{array}{l}100 \\
100 \\
100\end{array}$ & $\begin{array}{l}90-100 \\
95-100 \\
90-100\end{array}$ & $\begin{array}{l}70-90 \\
90-95 \\
70-80\end{array}$ & $\begin{array}{l}0.63-2.0 \\
0.06-0.2 \\
0.2-0.63\end{array}$ & $\begin{array}{l}0.17-0.19 \\
0.18-0.20 \\
0.17-0.19\end{array}$ & $\begin{array}{l}\text { 6. } 1-6.5 \\
5.6-6.0 \\
7.4-8.4\end{array}$ & $\begin{array}{l}\text { Moderate or blgh } \\
\text { Moderate or high.... } \\
\text { Moderate...... }\end{array}$ & $\begin{array}{l}\text { Low. } \\
\text { High. } \\
\text { Moderate. }\end{array}$ \\
\hline $\begin{array}{r}100 \\
100 \\
100 \\
35-45\end{array}$ & $\begin{array}{l}90-100 \\
95-100 \\
90-100 \\
20-30\end{array}$ & $\begin{array}{r}70-90 \\
90-95 \\
70-80 \\
5-12\end{array}$ & $\begin{array}{l}0.63-2.0 \\
0.06-0.24 \\
0.2-0.63 \\
6.3-20.0\end{array}$ & $\begin{array}{l}0.17-0.19 \\
0.18-0.20 \\
0.17-0.19 \\
0.03-0.05\end{array}$ & $\begin{array}{l}\text { 5. } 6-6.5 \\
5.6-6.0 \\
7.4-7.8 \\
7.4-8.4\end{array}$ & $\begin{array}{l}\text { Moderate or hgih } \\
\text { Moderate or bigh. } \\
\text { Moderate. } \\
\text { Low }\end{array}$ & $\begin{array}{l}\text { Low. } \\
\text { Higli. } \\
\text { Moderate. } \\
\text { Yery low. }\end{array}$ \\
\hline $\begin{array}{l}100 \\
100 \\
100\end{array}$ & $\begin{array}{l}95-100 \\
95-100 \\
90-100\end{array}$ & $\begin{array}{l}85-95 \\
90-95 \\
70-80\end{array}$ & $\begin{array}{l}0.2-0.63 \\
0.06-0.2 \\
0.2-0.63\end{array}$ & $\begin{array}{l}0.18-0.20 \\
0.18-0.20 \\
0.17-0.19\end{array}$ & $\begin{array}{l}6.1-6.5 \\
5.6-6.0 \\
7.4-8.4\end{array}$ & $\begin{array}{l}\text { Moderate or high } \\
\text { Moderate or blgh } \\
\text { Moderate......... }\end{array}$ & $\begin{array}{l}\text { Moderate or high. } \\
\text { Higli. } \\
\text { Moderate. }\end{array}$ \\
\hline $\begin{array}{r}100 \\
100 \\
35-45\end{array}$ & $\begin{array}{l}90-100 \\
85-100 \\
20-30\end{array}$ & $\begin{array}{r}70-90 \\
65-80 \\
5-12\end{array}$ & $\begin{array}{l}0.63-2.0 \\
0.63-2.0 \\
6.3-20.0\end{array}$ & $\begin{array}{l}0.17-0.19 \\
0.18-0.20 \\
0.03-0.05\end{array}$ & $\begin{array}{l}6.0-7.3 \\
5.0-7.3 \\
7.4-8.4\end{array}$ & $\begin{array}{l}\text { Moderate or bigh } \\
\text { Moderate } \\
\text { Low }\end{array}$ & $\begin{array}{l}\text { Low. } \\
\text { Moderate. } \\
\text { Low. }\end{array}$ \\
\hline $\begin{array}{l}100 \\
100 \\
100\end{array}$ & $\begin{array}{l}9.5-100 \\
95-100 \\
90-100\end{array}$ & $\begin{array}{l}85-95 \\
90-95 \\
70-90\end{array}$ & $\begin{array}{l}0.2-0.63 \\
0.06-0.2 \\
0.06-0.63\end{array}$ & $\begin{array}{l}0.18-0.20 \\
0.18-0.21 \\
0.17-0.19\end{array}$ & $\begin{array}{l}\text { 6. } 6-7.3 \\
\text { 6. } 6-7.3 \\
7.4-8.4\end{array}$ & $\begin{array}{l}\text { Moderate or high...... } \\
\text { Moderate or high...... } \\
\text { Moderate............. }\end{array}$ & $\begin{array}{l}\text { Moderate. } \\
\text { II igh. } \\
\text { Moderate. }\end{array}$ \\
\hline $\begin{array}{l}100 \\
100 \\
100\end{array}$ & $\begin{array}{l}95-100 \\
95-100 \\
90-100\end{array}$ & $\begin{array}{l}85-95 \\
85-95 \\
70-95\end{array}$ & $\begin{array}{l}0.2-0.63 \\
0.00-0.2 \\
0.06-0.63\end{array}$ & $\begin{array}{l}0.18-0.20 \\
0.18-0.20 \\
0.18-0.20\end{array}$ & $\begin{array}{l}\text { 6. } 6-7.3 \\
\text { B. } 6-7.3 \\
\text { 7. } 4-8.4\end{array}$ & $\begin{array}{l}\text { Moderate..... } \\
\text { Moderate or high } \\
\text { Moderate.................... }\end{array}$ & $\begin{array}{l}\text { Moderite. } \\
\text { Iligh. } \\
\text { Muderate. }\end{array}$ \\
\hline $\begin{array}{l}100 \\
1011 \\
100\end{array}$ & $\begin{array}{l}(15 i-1(1) \\
(11)-1(11) \\
51(-110\end{array}$ & 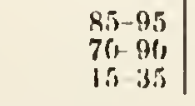 & $\begin{array}{l}0.2-0.63 \\
0.00-0.20 \\
2.01-6.11\end{array}$ & $\begin{array}{l}0.18-0.20 \\
0.18-1) .20 \\
0.11-0.17\end{array}$ & $\begin{array}{l}\text { 6. } 6-7.3 \\
0.0-7.3 \\
7.4-8.4\end{array}$ & $\begin{array}{l}\text { Moderate } \\
\text { Moderate........ } \\
\text { I.ow }\end{array}$ & $\begin{array}{l}\text { Modurste. } \\
\text { Mlotherate. } \\
\text { l.ow. }\end{array}$ \\
\hline
\end{tabular}


TABLE 6.- Estimated + mpinrering

\begin{tabular}{|c|c|c|c|c|c|}
\hline \multirow{2}{*}{ Soil series and map symbols } & \multirow{2}{*}{$\begin{array}{l}\text { Dejuh to } \\
\text { seasonal } \\
\text { lighl } \\
\text { water } \\
\text { table }\end{array}$} & \multirow{2}{*}{$\begin{array}{l}\text { Depth from } \\
\text { surface } \\
\text { (repre- } \\
\text { sentative } \\
\text { profile) }\end{array}$} & \multicolumn{3}{|c|}{ Clussificution } \\
\hline & & & Dominant USDA texture & Unified & A.ASIIO \\
\hline Ross: & $\stackrel{\text { Fecl }}{>}>5$ & $\begin{array}{l}\text { Inches } \\
0-30 \\
30-60\end{array}$ & $\begin{array}{l}\text { Silt loam } \\
\text { Silt loam or loam }\end{array}$ & $\begin{array}{l}\text { MI or } \mathrm{Cl} \text {, } \\
\mathrm{MI} \text {, or } \mathrm{CI} \text {. }\end{array}$ & $\begin{array}{l}A-4 \text { or } A-6 \\
A-4 \text { or } A-6\end{array}$ \\
\hline $\begin{array}{l}\text { Sebewa: } \\
\qquad \text { Se_................... }\end{array}$ & ${ }^{2} 0-3$ & $\begin{array}{r}0-11 \\
11-33 \\
33-60\end{array}$ & $\begin{array}{l}\text { Silty clay loam } \\
\text { Cluy loam or silty clay loam. } \\
\text { Stratified gravel and sand. }\end{array}$ & $\begin{array}{l}\text { CL or CII } \\
\text { Cl, or CII } \\
\text { GP }\end{array}$ & $\begin{array}{l}A-6 \text { or } A-7 \\
A-6 \text { or } A-7 \\
A-1\end{array}$ \\
\hline $\begin{array}{l}\text { Shonls: } \\
\text { Sh }\end{array}$ & $1-3$ & $\begin{array}{r}0-12 \\
12-30 \\
30-60\end{array}$ & $\begin{array}{l}\text { Silt loam } \\
\text { Silt loam clay loam, clay loam, or loam } \\
\text { Silty }\end{array}$ & $\begin{array}{l}\text { MII } \\
\text { CL }\end{array}$ & $\begin{array}{l}A-4 \\
\Lambda-4 \\
A-4 \text { or } A-6\end{array}$ \\
\hline $\begin{array}{l}\text { Slonn: } \\
\text { Sn }\end{array}$ & $20-3$ & $\begin{array}{r}0-13 \\
13-26 \\
26-60\end{array}$ & $\begin{array}{l}\text { Silt loam } \\
\text { Clay loam loam, loam, or loamy sand. }\end{array}$ & $\begin{array}{l}\text { ML or CI } \\
\text { CL or SC } \\
\mathrm{MI}, \mathrm{CJ} \text {, or } \mathrm{SMI}\end{array}$ & $\begin{array}{l}A-4 \text { or } A-6 \\
A-6 \text { or } A-7 \\
A-2 \text { or } A-4\end{array}$ \\
\hline $\begin{array}{l}\text { Wallkill: } \\
\text { Wa.................. }\end{array}$ & ${ }^{2} 0-2$ & $\begin{array}{r}0-17 \\
17-60\end{array}$ & $\begin{array}{l}\text { Silt loam } \\
\text { Muek and Peat }\end{array}$ & $\underset{\mathrm{Pt}}{\mathrm{ML}}$ or $\mathrm{CJ}$ & $A-4$ ir $A-6$ \\
\hline
\end{tabular}

\footnotetext{
Water table is perched.
} 
oroperties of the soils-Continued

\begin{tabular}{|c|c|c|c|c|c|c|c|}
\hline \multicolumn{3}{|c|}{ Percentage passing siev"(- } & \multirow{2}{*}{ Permeability } & \multirow{2}{*}{$\begin{array}{l}\text { Available } \\
\text { moisture } \\
\text { capacity }\end{array}$} & \multirow{2}{*}{ Reaction } & \multirow{2}{*}{ Frost-heave potential } & \multirow{2}{*}{$\begin{array}{l}\text { Shrink-spell } \\
\text { potential }\end{array}$} \\
\hline $\begin{array}{c}\text { No. } 10 \\
(2.0 \mathrm{~mm} .)\end{array}$ & $\begin{array}{c}\text { No. } 40 \\
(0.42 \mathrm{~mm} .)\end{array}$ & $\begin{array}{c}\text { No. } 200 \\
(0.074 \mathrm{~mm} .)\end{array}$ & & & & & \\
\hline $\begin{array}{l}100 \\
100\end{array}$ & $\begin{array}{l}90-100 \\
85-100\end{array}$ & $\begin{array}{l}70-90 \\
60-90\end{array}$ & $\begin{array}{l}\text { Inehes per hour } \\
0.63-2.0 \\
0.63-2.0\end{array}$ & $\begin{array}{l}\text { Inehes per ineh } \\
\text { of soil } \\
0.17-0.19 \\
0.17-0.19\end{array}$ & $\begin{array}{l}\text { pH value } \\
7.4-8.4 \\
7.4-8.4\end{array}$ & $\begin{array}{l}\text { Moderate } \\
\text { Moderate........ }\end{array}$ & $\begin{array}{l}\text { Low: } \\
\text { Low. }\end{array}$ \\
\hline $\begin{array}{rl} & 100 \\
90-100 & 25-35\end{array}$ & $\begin{array}{l}95-100 \\
70-80 \\
5-10\end{array}$ & $\begin{array}{c}85-95 \\
35-55 \\
0-5\end{array}$ & $\begin{array}{l}0.63-2.0 \\
0.63-2.0 \\
6.3-20.0\end{array}$ & $\begin{array}{l}0.18-0.20 \\
0.18-0.20 \\
0.03-0.05\end{array}$ & $\begin{array}{l}\text { 6. } 6-7.3 \\
\text { 6. } 6-7.3 \\
\text { 7. } 4-8.4\end{array}$ & $\begin{array}{l}\text { Moderate } \\
\text { Moderate..... } \\
\text { Low }\end{array}$ & $\begin{array}{l}\text { Low or moderatc. } \\
\text { Moderate. } \\
\text { Very low. }\end{array}$ \\
\hline $\begin{array}{l}100 \\
100 \\
100\end{array}$ & $\begin{array}{l}90-100 \\
90-100 \\
85-100\end{array}$ & $\begin{array}{l}70-90 \\
70-90 \\
60-80\end{array}$ & $\begin{array}{l}0.63-2.0 \\
0.63-2.0 \\
0.63-2.0\end{array}$ & $\begin{array}{l}0.17-0.19 \\
0.17-0.19 \\
0.17-0.19\end{array}$ & $\begin{array}{l}\text { 6. } 6-7.3 \\
6.6-7.8 \\
7.4-8.4\end{array}$ & $\begin{array}{l}\text { Moderate or high } \\
\text { Moderate or high } \\
\text { Moderate...... }\end{array}$ & $\begin{array}{l}\text { Low. } \\
\text { Low. } \\
\text { Moderate. }\end{array}$ \\
\hline $\begin{array}{r}100 \\
90-100 \\
100\end{array}$ & $\begin{array}{l}90-100 \\
70-80 \\
50-85\end{array}$ & $\begin{array}{l}70-90 \\
35-55 \\
15-75\end{array}$ & $\begin{array}{l}0.63-2.0 \\
0.2-0.63 \\
2.0-20.0\end{array}$ & $\begin{array}{l}0.17-0.19 \\
0.18-0.20 \\
0.14-0.18\end{array}$ & $\begin{array}{l}\text { 7. } 4-7.8 \\
\text { 7. } 4-8.4 \\
7.4-8.4\end{array}$ & $\begin{array}{l}\text { Moderate.... } \\
\text { Moderate.... } \\
\text { Low }\end{array}$ & $\begin{array}{l}\text { Low: } \\
\text { Moderate. } \\
\text { Low. }\end{array}$ \\
\hline 100 & $\begin{array}{r}90-100 \\
-\end{array}$ & $\begin{array}{r}70-90 \\
\cdots\end{array}$ & $\begin{array}{r}0.63-2.0 \\
2.0-6.3\end{array}$ & $\begin{array}{r}0.17-0.19 \\
>0.25\end{array}$ & $\begin{array}{l}\text { 6. } 6-7.3 \\
\text { 5. } 6-6.5\end{array}$ & $\begin{array}{l}\text { Moderate } \\
\text { Low }\end{array}$ & $\begin{array}{l}\text { Lor: } \\
\text { Low. }\end{array}$ \\
\hline
\end{tabular}

2 Ponded. 
Table 7.-Enginegring

[Not included in this table, because their characteristics are too variable to be elassified,

\begin{tabular}{|c|c|c|c|c|c|}
\hline \multirow{2}{*}{ Soil series and inap symbols } & \multicolumn{3}{|c|}{ Suitability as a sourec of- } & \multicolumn{2}{|c|}{ Soil features affecting- } \\
\hline & Topsoil & Sand and gravel & Road fill & Highway location & Reservoir area \\
\hline $\begin{array}{l}\text { Blount: } \\
\text { BIA, BIB, BIB2 } \ldots\end{array}$ & $\begin{array}{l}\text { Good to a depth } \\
\text { of } 9 \text { inches; } \\
\text { poor below; } \\
\text { clayey. }\end{array}$ & Not suitable _... & $\begin{array}{l}\text { Poor in subsoil: } \\
\text { high shriuk-swell } \\
\text { potential; lighly } \\
\text { plastic. } \\
\text { Fair to poor in sub- } \\
\text { stratum: mod- } \\
\text { erate shrink-swelt } \\
\text { potential; scasonal } \\
\text { high perched } \\
\text { water table. }\end{array}$ & $\begin{array}{l}\text { Seasonal high } \\
\text { perched witce } \\
\text { table; subject to } \\
\text { frost heating; } \\
\text { plastic elay below } \\
\text { the surface layer. }\end{array}$ & $\begin{array}{l}\text { Slow scepage; sea- } \\
\text { sonal ligh perclued } \\
\text { water table; clayey } \\
\text { subsoil atud } \\
\text { substratun. }\end{array}$ \\
\hline $\begin{array}{l}\text { Brookston: } \\
\text { Br. }\end{array}$ & $\begin{array}{l}\text { Fair or good to a } \\
\text { depth of } 12 \\
\text { inches; poor } \\
\text { below; moder- } \\
\text { ately fine } \\
\text { textured. }\end{array}$ & Not suitable.... & $\begin{array}{l}\text { Fair to poor in sub- } \\
\text { soil and substra- } \\
\text { tum: moderute } \\
\text { to low slirink- } \\
\text { swell potentiat; } \\
\text { subject to frost } \\
\text { heaving; seisonal } \\
\text { high wuter tablu. }\end{array}$ & $\begin{array}{l}\text { Seasonal high water } \\
\text { table; subject to } \\
\text { frost heaving; } \\
\text { moderately fine } \\
\text { textured subnoil. }\end{array}$ & $\begin{array}{l}\text { Seasonal high water } \\
\text { table; slow scep- } \\
\text { age; moderately } \\
\text { fine texturid } \\
\text { subsoil. }\end{array}$ \\
\hline Bs $\ldots \ldots \ldots$ & $\begin{array}{l}\text { Fair to a depth of } \\
12 \text { inches; poor } \\
\text { bclow; moder- } \\
\text { ately fine tex- } \\
\text { tured; cobble- } \\
\text { stones on sur- } \\
\text { face and in } \\
\text { subsoil. }\end{array}$ & Not suitable.... & $\begin{array}{l}\text { Poor in subsoil: } \\
\text { cobblestones and } \\
\text { boulders; seasonis } \\
\text { high water table. } \\
\text { Fair in substratin: } \\
\text { low shrink-swell } \\
\text { potential. }\end{array}$ & $\begin{array}{l}\text { senwonal high wuter } \\
\text { tuble; subject to } \\
\text { frost heaving; } \\
\text { cobblestones und } \\
\text { boulders jn subsoil. }\end{array}$ & $\begin{array}{l}\text { Seasonal high water } \\
\text { tabie; stow sorep- } \\
\text { age; cobblestones } \\
\text { and boulders in } \\
\text { subsoil. }\end{array}$ \\
\hline $\begin{array}{l}\text { Carlisle: } \\
\quad \mathrm{Ca}\end{array}$ & $\begin{array}{l}\text { Poor: organie } \\
\text { material sub- } \\
\text { sides rapidly; } \\
\text { erodible. }\end{array}$ & Not suitable.... & $\begin{array}{l}\text { Not suitable: or- } \\
\text { ganic; unstable; } \\
\text { high water table. }\end{array}$ & $\begin{array}{l}\text { Not suitable: un- } \\
\text { stable; high water } \\
\text { table; subject to } \\
\text { flooding. }\end{array}$ & $\begin{array}{l}\text { High water table; } \\
\text { organic material } \\
\text { susecptible to } \\
\text { flotation and } \\
\text { cave-in. }\end{array}$ \\
\hline $\begin{array}{l}\text { Crosby: } \\
\text { CrA }\end{array}$ & $\begin{array}{l}\text { Good to a depth of } \\
10 \text { inches; poor } \\
\text { loclow; moderut chl } \\
\text { fine textured. }\end{array}$ & Not suitable...-- & 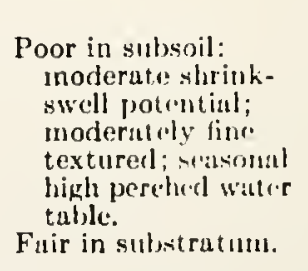 & 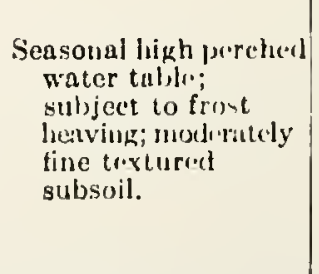 & 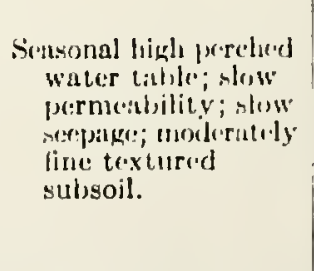 \\
\hline $\mathrm{C}_{s} \mathrm{~A}_{\ldots} \ldots \ldots \ldots$ & $\begin{array}{l}\text { Fair to a depth of } \\
10 \text { inchen; poor } \\
\text { betow; cobblic- } \\
\text { stones on surfuce } \\
\text { atud in subsoil. }\end{array}$ & Not suitabln.... & $\begin{array}{l}\text { Poor to fnir in sub- } \\
\text { soil: moderate } \\
\text { slirink-swell } \\
\text { potentiul; cobble- } \\
\text { stoncs and houther; } \\
\text { seasonal high } \\
\text { jurched water tulble. } \\
\text { Fuir to gond in } \\
\text { substratum. }\end{array}$ & $\begin{array}{l}\text { Sensonal high porched } \\
\text { water table; } \\
\text { cobblestoncs and } \\
\text { boulders in sub- } \\
\text { soil; subject to } \\
\text { frost heaving. }\end{array}$ & 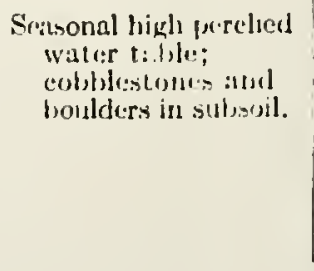 \\
\hline
\end{tabular}


interpretations of the soils

are the land types Borrow pits (Bp), Gravel pits and Stone quarrics (Gp), and Made land (Ma)]

\begin{tabular}{|c|c|c|c|c|c|c|}
\hline \multicolumn{5}{|c|}{ Soil features affecting-Continued } & \multicolumn{2}{|c|}{ Llmltations for serage disposal } \\
\hline Embankment & $\begin{array}{l}\text { Agricultural } \\
\text { drainage }\end{array}$ & $\begin{array}{l}\text { Terraces } \\
\text { and } \\
\text { diversions }\end{array}$ & $\begin{array}{c}\text { Grassed } \\
\text { waterways }\end{array}$ & $\begin{array}{l}\text { Foundations } \\
\text { for low } \\
\text { buildings }\end{array}$ & $\begin{array}{l}\text { Beptic tank } \\
\text { filter fields }\end{array}$ & Sewage lagoons \\
\hline $\begin{array}{l}\text { Clayey; medium to } \\
\text { high compressi- } \\
\text { bility; moderate } \\
\text { to high shrink- } \\
\text { swell potential. }\end{array}$ & $\begin{array}{l}\text { Slow permea- } \\
\text { bility; season- } \\
\text { al high } \\
\text { pcrched water } \\
\text { table. }\end{array}$ & $\begin{array}{l}\text { Dense clayey } \\
\text { subsoil; } \\
\text { difficult to } \\
\text { establish } \\
\text { vegetation. }\end{array}$ & $\begin{array}{l}\text { Dense clayey } \\
\text { subsoil; } \\
\text { highly erodi- } \\
\text { ble; gently } \\
\text { sloping. }\end{array}$ & $\begin{array}{l}\text { Shrink-swell po- } \\
\text { tential high in } \\
\text { subsoil and } \\
\text { moderate below } \\
\text { a depth of } 3 \\
\text { feet; seasonal } \\
\text { high perched } \\
\text { water table; } \\
\text { slow permea- } \\
\text { billty. }\end{array}$ & $\begin{array}{l}\text { Severe: seasonal } \\
\text { high perched } \\
\text { water table: } \\
\text { slow permean } \\
\text { bility. }\end{array}$ & Slight. \\
\hline $\begin{array}{l}\text { Moderately fine } \\
\text { textured; medium } \\
\text { to high coinpress- } \\
\text { ibility; moderate } \\
\text { to low shrink- } \\
\text { swell potential. }\end{array}$ & $\begin{array}{l}\text { Seasonal high } \\
\text { water tuble; } \\
\text { slow permea- } \\
\text { bility. }\end{array}$ & $\begin{array}{l}\text { Nearly level } \\
\text { and in de- } \\
\text { pressions; } \\
\text { runoff very } \\
\text { slow to } \\
\text { ponded. }\end{array}$ & $\begin{array}{l}\text { Features } \\
\text { generally } \\
\text { favorable. }\end{array}$ & $\begin{array}{l}\text { Shrink-swell po- } \\
\text { tentlal moderate } \\
\text { In subsoil and } \\
\text { low below a } \\
\text { deptl of } 4 \text { feet; } \\
\text { seasonal high } \\
\text { water table. }\end{array}$ & $\begin{array}{l}\text { Severe: seasonal } \\
\text { blgh rater } \\
\text { table; subject to } \\
\text { ponding; slow } \\
\text { permeability. }\end{array}$ & Slight. \\
\hline $\begin{array}{l}\text { Cobblestones and } \\
\text { boulders in sub- } \\
\text { soil; low to med- } \\
\text { ium compressibil- } \\
\text { ity in substratuin. }\end{array}$ & $\begin{array}{l}\text { Scasonal high } \\
\text { water table; } \\
\text { slow permea- } \\
\text { bility; cob- } \\
\text { blestones and } \\
\text { boulders on } \\
\text { surface and } \\
\text { in subsoil. }\end{array}$ & $\begin{array}{l}\text { Nearly level; } \\
\text { wetness; } \\
\text { cobble- } \\
\text { stoncs and } \\
\text { boulders in } \\
\text { subsoil. }\end{array}$ & $\begin{array}{l}\text { Cobblestones } \\
\text { and boulders } \\
\text { in suhsoil. }\end{array}$ & $\begin{array}{l}\text { Shrink-swell po- } \\
\text { tential moder- } \\
\text { ate in subsoil } \\
\text { and low below } \\
\text { a depth of } 31 / 2 \\
\text { feet; seasonal } \\
\text { high water } \\
\text { table. }\end{array}$ & $\begin{array}{l}\text { Severe: seasonal } \\
\text { hlgh water } \\
\text { table; subject } \\
\text { to ponding; } \\
\text { slow permea } \\
\text { bility. }\end{array}$ & $\begin{array}{l}\text { Moderate or } \\
\text { severe: } \\
\text { stones in } \\
\text { subsoil and } \\
\text { substratum. }\end{array}$ \\
\hline $\begin{array}{l}\text { Organic; unstable; } \\
\text { highly compress- } \\
\text { ible. }\end{array}$ & $\begin{array}{l}\text { Organic mate- } \\
\text { rial subject to } \\
\text { subsidence; } \\
\text { poor outlets; } \\
\text { high water } \\
\text { table. }\end{array}$ & $\begin{array}{l}\text { Nearly level } \\
\text { and in de- } \\
\text { pressions; } \\
\text { wetness. }\end{array}$ & $\begin{array}{l}\text { Runoff very } \\
\text { slow; ponded } \\
\text { in places; low } \\
\text { in available } \\
\text { phosphorus } \\
\text { and potas- } \\
\text { sium. }\end{array}$ & $\begin{array}{l}\text { Unstable; organic; } \\
\text { high water } \\
\text { table. }\end{array}$ & $\begin{array}{l}\text { Severe: high } \\
\text { water table; } \\
\text { nearly level and } \\
\text { in depressions. }\end{array}$ & $\begin{array}{l}\text { Severe: high } \\
\text { content of } \\
\text { organle mot- } \\
\text { ter; nearly } \\
\text { level and in } \\
\text { depressiols; } \\
\text { frequently" } \\
\text { ponded; } \\
\text { dralnage } \\
\text { Irom higher } \\
\text { areas. }\end{array}$ \\
\hline $\begin{array}{l}\text { Slow pcrmeability; } \\
\text { moderately fine } \\
\text { textured subsoil; } \\
\text { fair stability and } \\
\text { compaction. }\end{array}$ & $\begin{array}{l}\text { Slow permea- } \\
\text { bility; } \\
\text { scasonal high } \\
\text { perched water } \\
\text { table. }\end{array}$ & $\begin{array}{l}\text { Features } \\
\text { generally } \\
\text { are favorable. }\end{array}$ & $\begin{array}{l}\text { Dense moderately } \\
\text { fine textured } \\
\text { subsoil; } \\
\text { moderately } \\
\text { erodible. }\end{array}$ & $\begin{array}{l}\text { Shrink-swell } \\
\text { potential } \\
\text { moderate in } \\
\text { subsoil and low } \\
\text { below a depth of } \\
3 \text { feet; seasonal } \\
\text { high perched } \\
\text { watcr table. }\end{array}$ & $\begin{array}{l}\text { Severe: seasonal } \\
\text { high perched } \\
\text { water table; } \\
\text { slow } \\
\text { permeability. }\end{array}$ & Slight. \\
\hline $\begin{array}{l}\text { Slow permeability; } \\
\text { cobblestones and } \\
\text { boulders in sub- } \\
\text { soil; low } \\
\text { compressibility. }\end{array}$ & $\begin{array}{l}\text { Cobblestones } \\
\text { and boulders } \\
\text { in subsoil; } \\
\text { seasonal high } \\
\text { perched water } \\
\text { table; slow } \\
\text { permeability. }\end{array}$ & $\begin{array}{l}\text { Cobblestones } \\
\text { and boulders } \\
\text { in subsoil. }\end{array}$ & $\begin{array}{l}\text { Cobblestones } \\
\text { and boulders } \\
\text { in subsoil. }\end{array}$ & $\begin{array}{l}\text { Shrink-swell } \\
\text { potential } \\
\text { moderate in sub- } \\
\text { soil and low } \\
\text { below a depth of } \\
3 \text { feet; scasonal } \\
\text { high perclicd } \\
\text { water table. }\end{array}$ & $\begin{array}{l}\text { Severe: slow } \\
\text { permeability; } \\
\text { seasonal high } \\
\text { perched water } \\
\text { tablc. }\end{array}$ & $\begin{array}{l}\text { Moderate or } \\
\text { severe: stones } \\
\text { in subsoil and } \\
\text { sub-tratum. }\end{array}$ \\
\hline
\end{tabular}




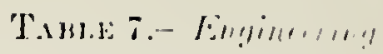

Suitubility as a souree of-

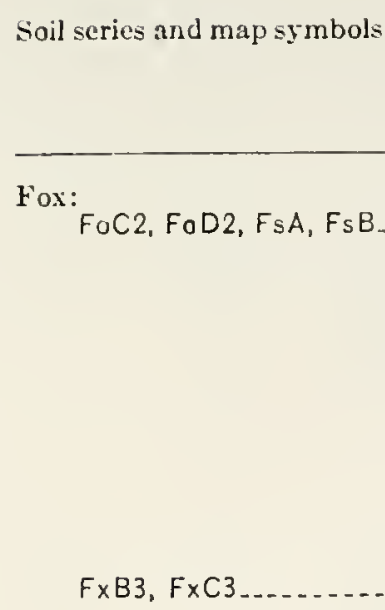

Gencsec:

$\mathrm{Ge}$

IIennepin: $\mathrm{HeE}$.

Kokomo:

$\mathrm{Km}$

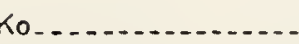

Fair to a depth of 16 inclies; poor below; clayey; hish water table.

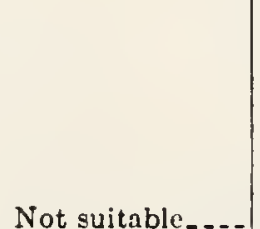

Not suitable....

\begin{tabular}{|c|c|} 
Sand and gravel & Road fill \\
\hline $\begin{array}{c}\text { Good below a } \\
\text { dejth of } 20 \text { to }\end{array}$ & $\begin{array}{c}\text { Fair to a depth of } 20 \\
\text { to } 40 \text { inclies; good }\end{array}$
\end{tabular}

9 inches: poor below; gravelly; moderately finc textured.

Poor in surface layer and subsoil; moderately. fine textured: gravelly.

Good to a deptls of 30 inehes.

Fair to a depth of 6 inches; steep; poor in subsoil.

Fair to good to a depth of 10 inches; poor in subsoil; elayey and gravelly.

$$
40 \text { inches. }
$$

\section{Good below a depth of 20 to 40 inches.}

Fair to a depth of 20 to 40 inehes; good below.

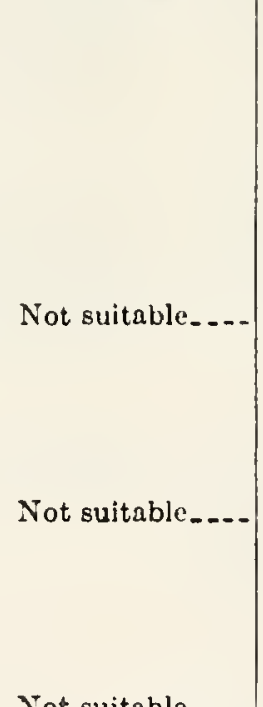

Not suitable....

Poor in subsoil: clayey and plastic.

Fair in substratum: high water table. cult to work and eompaet if wet; highly arodible.

air: subject to flooding.

Poor in subsoil:

clayey and plastic. Fair in substratum: high watcr table.

Soil features alfucting-

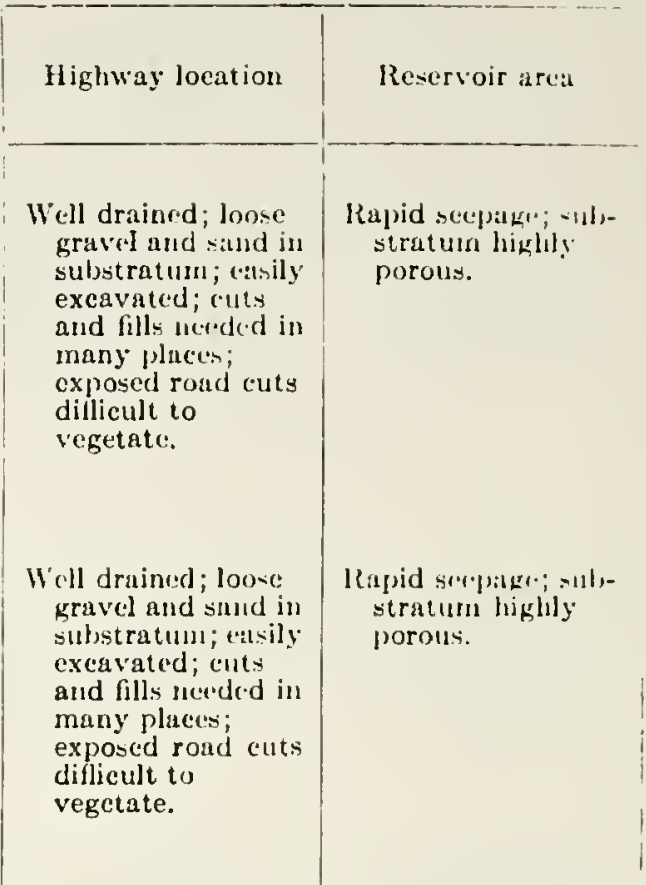

Subject to flooding; sulject to frost heaving.

Cuts and fills ure nceded; diflieult to vegetate rond cuts; very crodible.

High water tille; subject to frost heaving; elayry subsoil; subject to ponding.

High water tuls]e; subject to frost heaving; elay'y subsoil; sul,ject to ponding.
Sinbject to llooditu: noderale s'epilge".

Not suituble: stexp-

Uligh water tuble; nlow serplatas:; clayey sulssoil.
IIgh watrer tulle:; slow serpatge: clagey" subsoil. 
Soil features alfecting-Continued

Embankment
Fair to good stability
and eompaetion in
subsoil; good sta-
bility and eompac-
tion in sub-
stratum; rajpid
pernenbility.

Fair to good stability and compaction in subsoil; good stability and compretion in substratum; rapid permenbility.

Moderate permeability; fair stability; fair compration.

Fuir stability and compaction; medium compressibility.

Fair stability, fair to good compaction, and slight to medium eompressilsility in sulssoil ; fair stability, fair compaction, and nedium compressibility in suhstr:tum.

Fair stability, fair to good compricetion, slow permeability, and slight to medium comjressibility in sulssoil.

Fair stability, fair compaction, and rnedium compressibility in sulbstralum; contiilss stritified sanrl, silt, and smulu: gratvel. sions: poor

\begin{tabular}{|c|c|c|c|}
\hline $\begin{array}{l}\text { Agricultural } \\
\text { drainage }\end{array}$ & $\begin{array}{l}\text { Terraees } \\
\text { and } \\
\text { diversions }\end{array}$ & $\begin{array}{c}\text { Grassed } \\
\text { waterways }\end{array}$ & $\begin{array}{l}\text { Foundations } \\
\text { for low } \\
\text { buildings }\end{array}$ \\
\hline $\begin{array}{l}\text { Generally well } \\
\text { drained; } \\
\text { strong short } \\
\text { slopes in } \\
\text { plaees; hazard } \\
\text { of erosion; } \\
\text { drollghty. }\end{array}$ & $\begin{array}{l}\text { Sand and } \\
\text { gravel at a } \\
\text { depth of } 20 \\
\text { to } 40 \text { inches. }\end{array}$ & $\begin{array}{l}\text { Sand and gravel } \\
\text { at a depth of } \\
20 \text { to } 40 \text { inches. }\end{array}$ & $\begin{array}{l}\text { Low compressi- } \\
\text { bility; loose } \\
\text { gravel and sand } \\
\text { below a depth of } \\
20 \text { to } 40 \text { inches. }\end{array}$ \\
\hline $\begin{array}{l}\text { Well drained; } \\
\text { short unevon } \\
\text { Mlopes; hazard } \\
\text { of erosion; } \\
\text { drolighty. }\end{array}$ & $\begin{array}{l}\text { Sand and } \\
\text { gravel at a } \\
\text { depth of } 20 \\
\text { to } 40 \text { inches. }\end{array}$ & $\begin{array}{l}\text { Sand and gravel } \\
\text { at a depth of } \\
20 \text { to } 40 \\
\text { inches. }\end{array}$ & $\begin{array}{l}\text { Low compressl- } \\
\text { bility; loose } \\
\text { gravel and sand } \\
\text { below a depth of } \\
20 \text { to } 40 \text { inches. }\end{array}$ \\
\hline
\end{tabular}

Soil features

favorable:subjeet to flooding; nearly level.

Well drained... -

\section{Short, steep slopes; highly erod- ible.}

On nearly level flood plains; runoff is slow.

Jigh water talle; slow perme:tbility; in depressions; poor autluts.

Hligh water table; slow permeability in depresoutlets.

Nearly level.....

\section{Steep slopes:} diffieult to vegetate; highly erodible.

Nearly level Nearly leve! and in de- and in depressions.

pressions; very poorly drained; low iil phosphorus and potassium.

Nearly level pressions.

Nearly level and in depressions: clavey subsoil; wetness.
Limitations for sewage divpo-al

\begin{tabular}{|c|c|}
\hline $\begin{array}{l}\text { Septic tank } \\
\text { filter ficlds }\end{array}$ & Serage lagoons \\
\hline $\begin{array}{l}\text { Slight on slopes of } \\
\text { not more than } 6 \\
\text { percent; } \\
\text { moderate } \\
\text { on slopes of } 6 \text { to } \\
12 \text { percent; } \\
\text { severe on slopes } \\
\text { of more than } 12 \\
\text { pereent; possible } \\
\text { pollution of } \\
\text { shallow rells } \\
\text { by effuent. }\end{array}$ & $\begin{array}{l}\text { Severe: loose } \\
\text { porous gravel } \\
\text { and sand at a } \\
\text { deptb of } 20 \text { lo } \\
40 \text { inches. }\end{array}$ \\
\hline $\begin{array}{l}\text { Slight on slopes of } \\
\text { not more than } 6 \\
\text { percent; } \\
\text { moderate on }\end{array}$ & $\begin{array}{l}\text { Severe: loose } \\
\text { porous gravel } \\
\text { and sand at } \\
\text { depth of } 20 \text { to }\end{array}$ \\
\hline
\end{tabular}

slopes of 8 to 12 percent; severe on slopes of more than 12 percent; possiblo pollution of shallow wells by effluent.
On flood plains and subjeet to flooding.

Severe: subject to flooding.

Severe:

moderate

permeabilits: subject to flooding.

Steep slopes...... Severe on slopes of more than 18 percent.

Slight to medium compressibility and moderate swell potential in subsoil; high water table.

Medium compressibility; moderate or high shrinkswell potential in sulssoil; bigh water table.
Severe: high nater table; subject to ponding; slor permeability.

Severe: high water tilile; subject to ponding; slow permeability. or high shrink-
Severo on slopes of more thut 18 pereent.

Severe: subject to pond. ing; drainales arens.

Severe: subjeet to pondilig. from higher 
'T.ABLE 7.-E!nginurin!)

\begin{tabular}{|c|c|c|c|c|c|}
\hline \multirow{2}{*}{ Soil scrics and map symbols } & \multicolumn{3}{|c|}{ Suit:ability as a source of-- } & \multicolumn{2}{|c|}{ Soil foaltures alfoeling -- } \\
\hline & Topsoil & Sand and gravel & Road fill & Highway location & Reservoir arca \\
\hline $\begin{array}{l}\text { Linwood: } \\
\quad \text { Lm }\end{array}$ & $\begin{array}{l}\text { Poor: organic } \\
\text { matcrial sulb- } \\
\text { sides riljidly; } \\
\text { erodible. }\end{array}$ & Not suitable _... & $\begin{array}{l}\text { Poor in organic ma- } \\
\text { terial: unstable; } \\
\text { high water table. } \\
\text { Fair to poor below } \\
\text { organie layer. }\end{array}$ & $\begin{array}{l}\text { Organic material to } \\
\text { a deptly of } 12 \text { to } \\
40 \text { inches; lijgh } \\
\text { water talje; sub- } \\
\text { ject to fro-t } \\
\text { heaving; low re- } \\
\text { lief; subjeet to } \\
\text { ponding. }\end{array}$ & 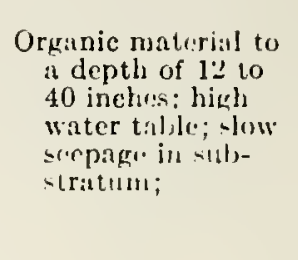 \\
\hline $\begin{array}{l}\text { Martinswille: } \\
\text { MdC2 }\end{array}$ & 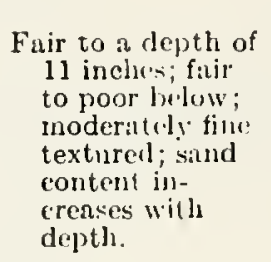 & Not suitable ... & $\begin{array}{l}\text { Good in subsoil; } \\
\text { fair to good in } \\
\text { substratum. }\end{array}$ & $\begin{array}{l}\text { Cuts and fills } \\
\text { lieeded. }\end{array}$ & $\begin{array}{l}\text { Moderate secesul"; } \\
\text { ytratified sinfl } \\
\text { and sill in sul- } \\
\text { stratum. }\end{array}$ \\
\hline MeA, MeB........ & 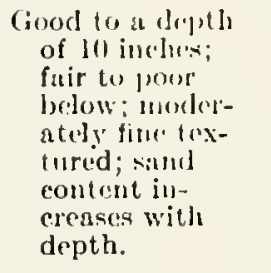 & Not suitable . . . & $\begin{array}{l}\text { Good in subsoil } \\
\text { fair to good in } \\
\text { substratum. }\end{array}$ & $\begin{array}{l}\text { Cuts and tills } \\
\text { needed. }\end{array}$ & 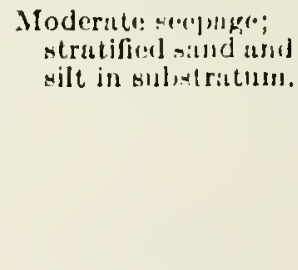 \\
\hline $\begin{array}{l}\text { Miami: } \\
\qquad \begin{array}{l}\mathrm{MmA}, \mathrm{MmB2}, \mathrm{MmC2} \\
\mathrm{MmD}\end{array}\end{array}$ & $\begin{array}{l}\text { Good to a depth } \\
\text { of } 8 \text { inelies; } \\
\text { poor below. }\end{array}$ & Not suitable . . . & $\begin{array}{l}\text { Poor in subsoil: } \\
\text { moderately fine } \\
\text { textured; plastic. } \\
\text { Fair to poor in sub- } \\
\text { stratum: low } \\
\text { shrink-swell po- } \\
\text { tential; difficult to } \\
\text { work and com- } \\
\text { paet if wet. }\end{array}$ & $\begin{array}{l}\text { Cuts and fills } \\
\text { necded; subject to } \\
\text { frost heaving; } \\
\text { moderately tine } \\
\text { textured subsoil. }\end{array}$ & $\begin{array}{l}\text { Moderate to slow } \\
\text { seepage; moder- } \\
\text { ately fine textured } \\
\text { subsoil. }\end{array}$ \\
\hline $\mathrm{MnA}, \mathrm{MnB}, \mathrm{MnC2} \ldots$ & $\begin{array}{l}\text { Good to a depth } \\
\text { of } 8 \text { inehes; } \\
\text { poor below. }\end{array}$ & $\begin{array}{l}\text { Good below a } \\
\text { depth of } 4 \text { to } \\
10 \text { feet. }\end{array}$ & $\begin{array}{l}\text { Poor in subsoil: } \\
\text { plastic; moder- } \\
\text { ately fine tex- } \\
\text { tured. } \\
\text { Good in sub- } \\
\text { stratum. }\end{array}$ & $\begin{array}{l}\text { Cuts and fills } \\
\text { needed; subject to } \\
\text { frost heaving; } \\
\text { moderately fine } \\
\text { textured subsoil; } \\
\text { loose gravel mud } \\
\text { sand at a depth } \\
\text { of } 4 \text { to } 10 \text { fert. }\end{array}$ & $\begin{array}{l}\text { Rapid seepage in } \\
\text { stratificl sand } \\
\text { and gravel. }\end{array}$ \\
\hline MoA, MoB............. & $\begin{array}{l}\text { Good to a depth } \\
\text { of } 8 \text { inches; } \\
\text { poor below. }\end{array}$ & Not suitable _... & $\begin{array}{l}\text { Poor in subsoil: } \\
\text { plastic; moder- } \\
\text { ately fine tex- } \\
\text { tured. } \\
\text { Poor in substratum: } \\
\text { moderate shrink- } \\
\text { 8well potential; } \\
\text { difficult to work } \\
\text { and compact if } \\
\text { wet. }\end{array}$ & $\begin{array}{l}\text { Cuts and fills } \\
\text { needed; subject } \\
\text { to frost heiting; } \\
\text { plastie; modir- } \\
\text { ately fine tex- } \\
\text { tured below it } \\
\text { depth of } 3 \text { feet. }\end{array}$ & $\begin{array}{l}\text { Moderate to How } \\
\text { secpagr. }\end{array}$ \\
\hline
\end{tabular}


Soil features affccing-Continucd

Embankment
Unstable orgunic
material to u
depth of 12 to 40
inclies; fair sta-
bility, fair com-
paction, and me-
diun compressi-
bility in substra-
tum.
Fair to good sta-
bility and com-
paction and ne-
dium compressi-
bility in subsoil
and substratum.

Fair to good stability and compaction and medium compressibility in subsoil and substratum.

Fair stability and conipaction; moderately fine textured subsoil.

$\cdot$

Fair stability and compaction; moderately fine textured subsoil.

Well drained....

All fertures favorable, if slopes are uniform.

Well drained...-

Most features
Fair stability and compaction; mediun to ligh compressibility.

\begin{tabular}{|c|c|c|c|}
\hline $\begin{array}{l}\text { Agricultural } \\
\text { drainage }\end{array}$ & $\begin{array}{l}\text { Terraces } \\
\text { and } \\
\text { diversions }\end{array}$ & $\begin{array}{c}\text { Grassed } \\
\text { waterways }\end{array}$ & $\begin{array}{c}\text { Foundations } \\
\text { for low } \\
\text { bulldings }\end{array}$ \\
\hline $\begin{array}{l}\text { Organic ma- } \\
\text { terial sub- } \\
\text { ject to sul- } \\
\text { sidence; high } \\
\text { water table; } \\
\text { poor outlets. }\end{array}$ & $\begin{array}{l}\text { In depres- } \\
\text { sions; run- } \\
\text { off very } \\
\text { slow; } \\
\text { ponded in } \\
\text { places; or- } \\
\text { ganic ma- } \\
\text { terial. }\end{array}$ & $\begin{array}{l}\text { Very poorly } \\
\text { drained; wet- } \\
\text { ness; low in } \\
\text { phosphorus } \\
\text { and potas- } \\
\text { sium. }\end{array}$ & $\begin{array}{l}\text { Unstable organio } \\
\text { material to a } \\
\text { depth of } 12 \text { to } \\
40 \text { inches; high } \\
\text { water table. }\end{array}$ \\
\hline Well drained... & $\begin{array}{l}\text { Most features } \\
\text { favorable, } \\
\text { depending } \\
\text { on slope. }\end{array}$ & $\begin{array}{l}\text { All features } \\
\text { favorable. }\end{array}$ & $\begin{array}{l}\text { Deep; permeable; } \\
\text { moderate to low } \\
\text { shrlnk-swell } \\
\text { potential. }\end{array}$ \\
\hline Well drained.... & $\begin{array}{l}\text { Most features } \\
\text { favorable, } \\
\text { depending } \\
\text { on slope. }\end{array}$ & $\begin{array}{l}\text { All features } \\
\text { favorable. }\end{array}$ & $\begin{array}{l}\text { Deep; permeable; } \\
\text { moderate to low } \\
\text { shrink-8well } \\
\text { potential. }\end{array}$ \\
\hline
\end{tabular}

Well dralned....

Highly eradible Shrink-8well pomore than $\theta$ ate in subsoil percent; no limitations on lesser slopes; high runoff.
Limitations for $\varepsilon$ c mage dispr-al

\begin{tabular}{|c|c|}
\hline $\begin{array}{l}\text { Septic tank } \\
\text { filter fields }\end{array}$ & Senage lagnon: \\
\hline $\begin{array}{l}\text { Severe: high } \\
\text { water table; } \\
\text { subject to } \\
\text { ponding. }\end{array}$ & $\begin{array}{l}\text { Severe: organie } \\
\text { material. }\end{array}$ \\
\hline $\begin{array}{l}\text { Slight: possible } \\
\text { pollution of } \\
\text { shallow wells } \\
\text { by eftluent. }\end{array}$ & $\begin{array}{l}\text { Severe: strati- } \\
\text { Ged sand and } \\
\text { silt in sub- } \\
\text { stratum. }\end{array}$ \\
\hline $\begin{array}{l}\text { Slight: possible } \\
\text { pollution of } \\
\text { shallow wells by } \\
\text { effluent. }\end{array}$ & $\begin{array}{l}\text { Severe: strati- } \\
\text { fed sand and } \\
\text { silt In sub- } \\
\text { stratum. }\end{array}$ \\
\hline
\end{tabular}
favorablo, favorable, if slopes are uniform.

Features generally f氏vorable on slopes of 6 percent or less; highly erodible on slopes of more than 6 percent; high runoff.

Features generally favorif slopes are unl. able. and low to very

form.
Shrink-swell potential moderate in subsoil low in substratum.

and low at a depth of 2 to 3 feet.

\section{Shrink-8well po-} tentlal moderate In subsoll and substratum.
Moderate on slopes of not more than 12 percent; severe on slopes of more than 12 percent; moderato permeability.

Moderate on slopes of not more than 12 percent; moderate permeability.

Severe on slopes of more than 12 percent; possible pollution of shallow wells by eftuent.

Moderate: moderate permea. billty.
Slight on slopes of not more than 2 perate on slopes of 2 to 6 percent; severe on slopes of more than 0 percent.

Severe: loose porous gravel and sand at a deptb of 4 to 10 fect.

Slight on slopes of not nlure tban 2 percent; inoderste on slopes of 2 to 13 percent. cent; moder- 
'TABLe 7.--linginerrin!

\begin{tabular}{|c|c|c|c|c|c|}
\hline \multirow{2}{*}{ Soil serics and map symbols } & \multicolumn{3}{|c|}{ Suitability as a souree of- } & \multicolumn{2}{|c|}{ Soil fratures affecting- } \\
\hline & 'Topsoil & Sand and gravel & Road fill & Highway location & Reservoir area \\
\hline $\begin{array}{l}\text { Miami-Continued } \\
\text { MrB3, MrC3 }\end{array}$ & $\begin{array}{l}\text { Poor in surface } \\
\text { layer and suls- } \\
\text { soil; noder- } \\
\text { ately fine tex- } \\
\text { tured. }\end{array}$ & Not suitable.... & $\begin{array}{l}\text { Poor in subsoil: } \\
\text { plastic; moder- } \\
\text { ately fine tex- } \\
\text { tured. } \\
\text { Fair to poor in sul,- } \\
\text { stratum: mod- } \\
\text { erate shrink- } \\
\text { swell potential; } \\
\text { difficult to work } \\
\text { and compact if } \\
\text { wet. }\end{array}$ & $\begin{array}{l}\text { Cuts and fills } \\
\text { needod; subject } \\
\text { to frost he'aving; } \\
\text { noderately fine } \\
\text { textured subsoil. }\end{array}$ & $\begin{array}{l}\text { Modcrite to slow } \\
\text { serpiste. }\end{array}$ \\
\hline $\begin{array}{l}\text { Morley: } \\
\text { MuB, MuB2, MuD2 }\end{array}$ & $\begin{array}{l}\text { Fair-to good to a } \\
\text { depth of } 8 \\
\text { inches; poor } \\
\text { below; clizyey. }\end{array}$ & Not suitable.... & $\begin{array}{l}\text { Poor in subsoil and } \\
\text { substratum: } \\
\text { moderate to high } \\
\text { shrink-swell } \\
\text { potential; plast ic } \\
\text { clay; difficult to } \\
\text { work; compaet } \\
\text { if wet. }\end{array}$ & $\begin{array}{l}\text { Cuts and fills } \\
\text { nceded; subject } \\
\text { to frost heaving; } \\
\text { plastic clay. }\end{array}$ & $\begin{array}{l}\text { Slow scepage; } \\
\text { clayey subsoil } \\
\text { and substratum. }\end{array}$ \\
\hline $\mathrm{M} v \mathrm{B2} ; \mathrm{M} \times \mathrm{C} 2 \ldots \ldots$ & $\begin{array}{l}\text { Fair to grood to a } \\
\text { depth of } 8 \\
\text { inches; poor } \\
\text { below; clayey. }\end{array}$ & $\begin{array}{l}\text { Good below a } \\
\text { depth of } 4 \text { to } \\
10 \text { feet. }\end{array}$ & $\begin{array}{l}\text { Poor in subsoil: } \\
\text { noderitte to high } \\
\text { slirink-swell } \\
\text { potential; plistic } \\
\text { clay. Good in } \\
\text { substratum. }\end{array}$ & $\begin{array}{l}\text { Cuts aud fills } \\
\text { nceded; sulbject } \\
\text { to frowt lustving; } \\
\text { plistic cluy; } \\
\text { crodes leadily. }\end{array}$ & 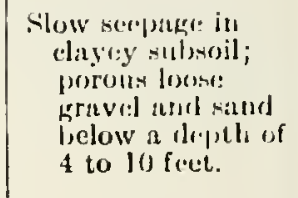 \\
\hline$M w B 3, M w C 3 \ldots . .$. & $\begin{array}{l}\text { Poor in surface } \\
\text { layer and in } \\
\text { subsoil; clayey. }\end{array}$ & Not suitable.... & $\begin{array}{l}\text { Poor in subsoil and } \\
\text { substratum: } \\
\text { moderate to high } \\
\text { shrink-swell } \\
\text { potential; plastic } \\
\text { clay. }\end{array}$ & $\begin{array}{l}\text { Cuts and fills } \\
\text { neecled; plistic } \\
\text { clity. }\end{array}$ & $\begin{array}{l}\text { Slow secputue; } \\
\text { clayey. }\end{array}$ \\
\hline $\begin{array}{l}\text { Oekley: } \\
\text { OcA, OcB }\end{array}$ & $\begin{array}{l}\text { Good to a depth } \\
\text { of } 10 \text { inclics; } \\
\text { poor below; } \\
\text { moderatcly fine } \\
\text { textured; } \\
\text { gravelly. }\end{array}$ & $\begin{array}{l}\text { Good below a } \\
\text { depth of } 42 \\
\text { inches. }\end{array}$ & $\begin{array}{l}\text { Fair to a depth of } \\
42 \text { inches and } \\
\text { good below. }\end{array}$ & $\begin{array}{l}\text { Well drained; } \\
\text { stratified gravel } \\
\text { and situd below } \\
\text { a daptl of } 42 \\
\text { inehes; etwily } \\
\text { excavated. }\end{array}$ & $\begin{array}{l}\text { Rapid nerpatge in } \\
\text { substratum. }\end{array}$ \\
\hline
\end{tabular}


intopretations of the soils-Continmed

\begin{tabular}{|c|c|c|c|c|c|c|}
\hline \multicolumn{5}{|c|}{ Soil features affecting-Continued } & \multicolumn{2}{|c|}{ Linitutions for sewage di-ju-..s } \\
\hline Embankment & $\begin{array}{l}\text { Agrieultural } \\
\text { drainage }\end{array}$ & $\begin{array}{l}\text { Terraces } \\
\text { and } \\
\text { diversions }\end{array}$ & $\begin{array}{c}\text { Grassed } \\
\text { waterways }\end{array}$ & $\begin{array}{l}\text { Foundations } \\
\text { for low } \\
\text { buildlngs }\end{array}$ & $\begin{array}{l}\text { Septic tank } \\
\text { filter fields }\end{array}$ & Sewage lagont:s \\
\hline $\begin{array}{l}\text { Fair stability and } \\
\text { compaction; me- } \\
\text { dium to high } \\
\text { compressibility. }\end{array}$ & Well drained...- & $\begin{array}{l}\text { Most features } \\
\text { favorable, } \\
\text { if slopes } \\
\text { are uni- } \\
\text { form. }\end{array}$ & $\begin{array}{l}\text { Features gen- } \\
\text { erally favor- } \\
\text { able. }\end{array}$ & $\begin{array}{l}\text { Sbrink-swell po- } \\
\text { tential moder- } \\
\text { ate in subsoil } \\
\text { and low in } \\
\text { substratum. }\end{array}$ & $\begin{array}{l}\text { Moderate on } \\
\text { slopes of } 2 \text { to } \\
12 \text { percent; se- } \\
\text { vere on slopes } \\
\text { of more than } 12 \\
\text { percent; moder- } \\
\text { ately slos to } \\
\text { moderate per- } \\
\text { meability. }\end{array}$ & 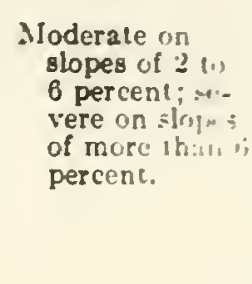 \\
\hline $\begin{array}{l}\text { Fair stability and } \\
\text { compaction; slow } \\
\text { permeability; } \\
\text { medium to high } \\
\text { compressibility; } \\
\text { claycy subsail. }\end{array}$ & Well drained .... & $\begin{array}{l}\text { Most features } \\
\text { favorable, } \\
\text { if slopes are } \\
\text { uniform. }\end{array}$ & $\begin{array}{l}\text { Dense clayey } \\
\text { gubsoil; } \\
\text { difficult to } \\
\text { vegetate. }\end{array}$ & $\begin{array}{l}\text { Shrink-swell } \\
\text { potential blgh } \\
\text { in subsoll and } \\
\text { moderate below } \\
\text { a depth of } 21 / 2 \\
\text { feet; slow } \\
\text { permeabllity. }\end{array}$ & $\begin{array}{l}\text { Severe: slow } \\
\text { permeability. }\end{array}$ & $\begin{array}{l}\text { Moderate on } \\
\text { slopes of I tu } \\
6 \text { percen! } \\
\text { severe oll } \\
\text { slopes of nur!s } \\
\text { than } 6 \text { prr- } \\
\text { cent. }\end{array}$ \\
\hline $\begin{array}{l}\text { Fair stability and } \\
\text { compaction; slow } \\
\text { permeability; } \\
\text { moderatc to high } \\
\text { shrink-swell } \\
\text { potential; } \\
\text { medium to high } \\
\text { compressibility; } \\
\text { elayey subsoil; } \\
\text { loose gravel and } \\
\text { sand below a } \\
\text { depth of } 4 \text { to } 10 \\
\text { feet. }\end{array}$ & Well drained.... & $\begin{array}{l}\text { Most features } \\
\text { favorable, } \\
\text { if slopes are } \\
\text { uniform. }\end{array}$ & $\begin{array}{l}\text { Clayey subsoil; } \\
\text { difficult to } \\
\text { vegetate. }\end{array}$ & $\begin{array}{l}\text { High shrink- } \\
\text { swell potential } \\
\text { in subsoil. }\end{array}$ & $\begin{array}{l}\text { Severe: slon } \\
\text { permeability. }\end{array}$ & $\begin{array}{l}\text { Severe: loo-r. } \\
\text { porous gravil } \\
\text { and sand } \\
\text { belou a deplal } \\
\text { of } 4 \text { to } 10 \\
\text { feet; lopers } \\
\text { of inorc than } \\
6 \text { percent. }\end{array}$ \\
\hline $\begin{array}{l}\text { Fair stability and } \\
\text { compaction; slow } \\
\text { permeability; } \\
\text { moderate to high } \\
\text { shrink-swell } \\
\text { potential; } \\
\text { medium to high } \\
\text { compressibility; } \\
\text { clayey subsoil. }\end{array}$ & Well drained.... & $\begin{array}{l}\text { Most features } \\
\text { favorable, } \\
\text { if slopes } \\
\text { are uni- } \\
\text { form; } \\
\text { difficult to } \\
\text { vegetate. }\end{array}$ & $\begin{array}{l}\text { Dense clayey } \\
\text { surface layer } \\
\text { and subsoil; } \\
\text { difficult to } \\
\text { vegetate. } \\
\text { - }\end{array}$ & $\begin{array}{l}\text { Sbrink-swell } \\
\text { potential high } \\
\text { in subsoil and } \\
\text { moderate below } \\
\text { a depth of } 2 \\
\text { feet. }\end{array}$ & $\begin{array}{l}\text { Severe: slow } \\
\text { permeability. }\end{array}$ & $\begin{array}{l}\text { Moderate on } \\
\text { slopes of :? to } \\
6 \text { percent; } \\
\text { severe on } \\
\text { slopes of } \\
\text { more than to } \\
\text { percent. }\end{array}$ \\
\hline $\begin{array}{l}\text { Fair stability, fair } \\
\text { compaction, and } \\
\text { slight to medium } \\
\text { compressibility } \\
\text { in subsoil; loose } \\
\text { gravel and sand, } \\
\text { good compaction, } \\
\text { fair to poor } \\
\text { stability, and } \\
\text { slight compres- } \\
\text { sibility in sub- } \\
\text { stratum. }\end{array}$ & Well drained.... & $\begin{array}{l}\text { Most features } \\
\text { favorable, } \\
\text { if slopes are } \\
\text { uniform. }\end{array}$ & $\begin{array}{l}\text { Features gen- } \\
\text { erally favor- } \\
\text { able. }\end{array}$ & $\begin{array}{l}\text { Deep; moderate } \\
\text { permeability; } \\
\text { moderate } \\
\text { sbrink-swell } \\
\text { potential in } \\
\text { subsoil; loose } \\
\text { gravel and sand } \\
\text { below a deptb } \\
\text { of } 42 \text { inches. }\end{array}$ & $\begin{array}{l}\text { Slight: possible } \\
\text { pollution of } \\
\text { shallow rells } \\
\text { by effiuent. }\end{array}$ & $\begin{array}{l}\text { Severe: gras. } \\
\text { elly in lower } \\
\text { subsoil: } \\
\text { porous loo... } \\
\text { grwel alsd } \\
\text { sand at } a \\
\text { depth of } 42 \\
\text { inches. }\end{array}$ \\
\hline
\end{tabular}




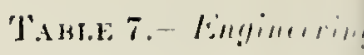

\begin{tabular}{|c|c|c|c|c|c|}
\hline \multirow{2}{*}{ Soil series and map symbols } & \multicolumn{3}{|c|}{ Suitability at a source of- } & \multicolumn{2}{|c|}{ Soil fe:tures alfecting - } \\
\hline & Topsoil & Sand and gravel & Iroad fill & Ilighway location & Reservoir urea \\
\hline $\begin{array}{l}\text { l'ewamo: } \\
\text { Pe... }\end{array}$ & $\begin{array}{l}\text { Fair to a depth of } \\
12 \text { inches; poor } \\
\text { below; clayey. }\end{array}$ & Not suitable... & $\begin{array}{l}\text { Poor in subsoil and } \\
\text { substratum: } \\
\text { diffieult to com- } \\
\text { paet; moderate to } \\
\text { high shrink-swell } \\
\text { potential; subject } \\
\text { to frost hcaving; } \\
\text { seasonal high } \\
\text { water table. }\end{array}$ & $\begin{array}{l}\text { Scasonal high watcr } \\
\text { table; subject to } \\
\text { frost heaving; } \\
\text { clayey below sur- } \\
\text { face layer. }\end{array}$ & 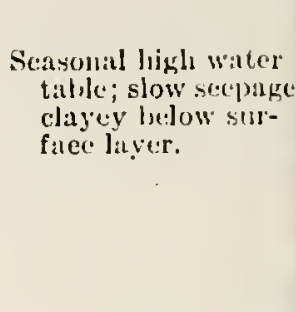 \\
\hline$P f_{--}$ & $\begin{array}{l}\text { Fair to a depth of } \\
12 \text { inehes; poor } \\
\text { bclow; clayey. }\end{array}$ & Not suitable $\ldots$ & $\begin{array}{l}\text { Poor in subsoil and } \\
\text { substratum: } \\
\text { moderate to high } \\
\text { shrink-swell } \\
\text { potential; plastic } \\
\text { clay diffeult to } \\
\text { compaet; seratonal } \\
\text { high water talsle. }\end{array}$ & $\begin{array}{l}\text { Seasonal high water } \\
\text { table; plastic } \\
\text { clay; clayey } \\
\text { sulbsoil. }\end{array}$ & $\begin{array}{l}\text { Slow scepage; claycy } \\
\text { sulbsoil; seasonial } \\
\text { high water table. }\end{array}$ \\
\hline $\begin{array}{l}\text { (For interpretations } \\
\text { of Brookston } \\
\text { soils in mapping } \\
\text { unit Pk, see } \\
\text { Brookston serics } \\
\text { in this table.) }\end{array}$ & $\begin{array}{l}\text { Good to at depth } \\
\text { of } 10 \text { in: } 20 \\
\text { inches; poor } \\
\text { ledow; chycy. }\end{array}$ & Not suitable... & $\begin{array}{l}\text { Poor in subsoil und } \\
\text { substrutum: } \\
\text { moderate to high } \\
\text { shrink-swell } \\
\text { potential; suljoct } \\
\text { to frost heaving; } \\
\text { plastic eluy; sch- } \\
\text { sonal high water } \\
\text { table. }\end{array}$ & $\begin{array}{l}\text { Scasonal high wuter } \\
\text { talble; sulbject to } \\
\text { frost heaving; } \\
\text { claycy bclow } \\
\text { surface layer; } \\
\text { subjecl to ponding. }\end{array}$ & $\begin{array}{l}\text { Srasonal ligh whter } \\
\text { tabble; slow } \\
\text { nerephe; cluyey } \\
\text { subsoil. }\end{array}$ \\
\hline $\begin{array}{l}\text { Rensselaer: } \\
\text { Rc...-- }\end{array}$ & $\begin{array}{l}\text { Fair or good to a } \\
\text { depth of } 12 \\
\text { inches; poor } \\
\text { below; moder- } \\
\text { ately fine } \\
\text { textured. }\end{array}$ & Not suitable.... & $\begin{array}{l}\text { Fair to poor in } \\
\text { subsoil: plastic; } \\
\text { moderately fine } \\
\text { textured. } \\
\text { Fair in substraturn: } \\
\text { silt and stratified } \\
\text { sand; seasonal } \\
\text { bigh water table. }\end{array}$ & $\begin{array}{l}\text { Seasonal high water } \\
\text { table; subject to } \\
\text { frost heaving; } \\
\text { moderately line } \\
\text { textured subsoil. }\end{array}$ & $\begin{array}{l}\text { Seasonal high wuter } \\
\text { table; moderate } \\
\text { to slow serpige; } \\
\text { moderately fint } \\
\text { textured subsoil. }\end{array}$ \\
\hline Ross: & $\begin{array}{l}\text { Good to a depth } \\
\text { of } 36 \text { inches. }\end{array}$ & Not suitable & $\begin{array}{l}\text { Fair: low shrink- } \\
\text { swell potential; } \\
\text { medium compres- } \\
\text { sibility; fair } \\
\text { stability. }\end{array}$ & $\begin{array}{l}\text { Subject to flooding; } \\
\text { subject to frost } \\
\text { heaving. }\end{array}$ & $\begin{array}{l}\text { Subject to flooding; } \\
\text { moderste to slow } \\
\text { secpange. }\end{array}$ \\
\hline $\begin{array}{c}\text { Sebewa: } \\
\text { Se... }\end{array}$ & $\begin{array}{l}\text { Fair or good to a } \\
\text { depth of } 11 \\
\text { inches; poor } \\
\text { below; moder- } \\
\text { ately fine } \\
\text { textured; } \\
\text { gravelly. }\end{array}$ & $\begin{array}{l}\text { Good below a } \\
\text { depth of } 24 \\
\text { to } 40 \text { inehes. }\end{array}$ & $\begin{array}{l}\text { Fair to poor in sub- } \\
\text { soil: low or } \\
\text { moderatc shrink- } \\
\text { swell potential; } \\
\text { seasonal high } \\
\text { water trble. } \\
\text { Good in sub- } \\
\text { gtratum: stratilicd } \\
\text { gravel and sand. }\end{array}$ & $\begin{array}{l}\text { Seasonal high water } \\
\text { table; subject to } \\
\text { frost heving; } \\
\text { loose gravel und } \\
\text { sand at a cleptl } \\
\text { of } 24 \text { to } 40 \text { inclies. } \\
\end{array}$ & 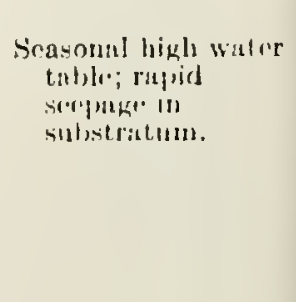 \\
\hline $\begin{array}{l}\text { Shoals: } \\
\text { Sh.... }\end{array}$ & $\begin{array}{l}\text { Good to a depth } \\
\text { of } 12 \text { inches; } \\
\text { good to poor } \\
\text { below; viriable } \\
\text { stratified layers. }\end{array}$ & Not suitable.... & $\begin{array}{l}\text { Fair: scasonal high } \\
\text { water table; } \\
\text { difficult to work } \\
\text { and compact if } \\
\text { wet. }\end{array}$ & $\begin{array}{l}\text { Subject to flooding; } \\
\text { srasonal hikht } \\
\text { witter tabls: } \\
\text { sulject to frost } \\
\text { heiving. }\end{array}$ & 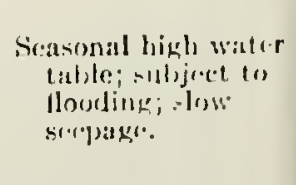 \\
\hline
\end{tabular}




\begin{tabular}{|c|c|c|c|c|c|c|}
\hline \multicolumn{5}{|c|}{ Soil features affecting--Contiuned } & \multicolumn{2}{|c|}{ Limitations for sewage di-|preal } \\
\hline Einbankment & $\begin{array}{l}\text { Agricultural } \\
\text { drainage }\end{array}$ & $\begin{array}{l}\text { Terraces } \\
\text { and } \\
\text { diversions }\end{array}$ & $\begin{array}{l}\text { Grassed } \\
\text { waternays }\end{array}$ & $\begin{array}{l}\text { Foundations } \\
\text { for low } \\
\text { buildings }\end{array}$ & $\begin{array}{l}\text { Beptic tank } \\
\text { flter ficlds }\end{array}$ & Sewage lakrom. \\
\hline $\begin{array}{l}\text { Fair stability and } \\
\text { compaction; slow } \\
\text { permeability; } \\
\text { medium to high } \\
\text { compressibility; } \\
\text { clayey subsoil. }\end{array}$ & $\begin{array}{l}\text { Seasonal high } \\
\text { water table; } \\
\text { slow per- } \\
\text { meability. }\end{array}$ & $\begin{array}{l}\text { Nearly level } \\
\text { and in } \\
\text { depressions. }\end{array}$ & $\begin{array}{l}\text { Very poorly } \\
\text { drained; ret- } \\
\text { ness; low in } \\
\text { phosphorus } \\
\text { and potas- } \\
\text { sium. }\end{array}$ & $\begin{array}{l}\text { Shrink-swell } \\
\text { potential high } \\
\text { in subsoil and } \\
\text { moderate below } \\
\text { a depth of } 4 \\
\text { feet; seasonal } \\
\text { higb water } \\
\text { table; slow per- } \\
\text { meability. }\end{array}$ & $\begin{array}{l}\text { Severe: seasonal } \\
\text { high water } \\
\text { table; subject } \\
\text { to ponding; } \\
\text { glow pernie- } \\
\text { ability. }\end{array}$ & $\begin{array}{l}\text { Slight: slow } \\
\text { permea- } \\
\text { bility; hikh } \\
\text { clay contolst. }\end{array}$ \\
\hline $\begin{array}{l}\text { Fair stability; slow } \\
\text { permcability; } \\
\text { claycy subsoil; } \\
\text { medium to high } \\
\text { compresibility. }\end{array}$ & $\begin{array}{l}\text { Seasonal high } \\
\text { water table; } \\
\text { slow perme- } \\
\text { ability. }\end{array}$ & $\begin{array}{l}\text { Nearly level } \\
\text { and in } \\
\text { depressions. }\end{array}$ & $\begin{array}{l}\text { Very poorly } \\
\text { drained; wet- } \\
\text { ness; low ill } \\
\text { phosphorus } \\
\text { and potas- } \\
\text { sium. }\end{array}$ & $\begin{array}{l}\text { Compressibility } \\
\text { and shrink- } \\
\text { swell potential } \\
\text { high in subsoil } \\
\text { and moderate } \\
\text { below a depth } \\
\text { of } 4 \text { feet; sea- } \\
\text { sonal high } \\
\text { water table. }\end{array}$ & $\begin{array}{l}\text { Severe: slow } \\
\text { permeability; } \\
\text { seasonal high } \\
\text { water table. }\end{array}$ & $\begin{array}{l}\text { Slight: alow } \\
\text { permealjility } \\
\text { high cla! } \\
\text { conteut. }\end{array}$ \\
\hline $\begin{array}{l}\text { Fair stability and } \\
\text { compaction; slow } \\
\text { permealjility } \\
\text { medium to high } \\
\text { compressibility; } \\
\text { clayey subsoil. }\end{array}$ & $\begin{array}{l}\text { Scasomal hixh } \\
\text { water table; } \\
\text { slow perinca- } \\
\text { bility; poor } \\
\text { outlets; sub- } \\
\text { ject to pond- } \\
\text { ing. }\end{array}$ & $\begin{array}{l}\text { Nearly level } \\
\text { and in } \\
\text { depressions. }\end{array}$ & $\begin{array}{l}\text { Subject to } \\
\text { ponding; } \\
\text { wetness. }\end{array}$ & $\begin{array}{l}\text { Shrink-swell po- } \\
\text { tential moderate } \\
\text { to high in sub- } \\
\text { soil and moder- } \\
\text { ate below a } \\
\text { depth of } 4 \text { feet; } \\
\text { seasonal high } \\
\text { water table; } \\
\text { slow permea- } \\
\text { bllity; subject } \\
\text { to ponding. }\end{array}$ & $\begin{array}{l}\text { Severe: seasonal } \\
\text { high water } \\
\text { table; slow per- } \\
\text { meability; sub- } \\
\text { ject to ponding. }\end{array}$ & Slight. \\
\hline $\begin{array}{l}\text { Fair stability, fair } \\
\text { to good compac- } \\
\text { tion, medium } \\
\text { compressibility, } \\
\text { and slow permen- } \\
\text { bility in subsoil; } \\
\text { fair stability, fair } \\
\text { compaction, and } \\
\text { medium coupres- } \\
\text { sibility in sub- } \\
\text { stratum. }\end{array}$ & $\begin{array}{l}\text { Seasonal high } \\
\text { water table; } \\
\text { slow permea- } \\
\text { bility. }\end{array}$ & $\begin{array}{l}\text { Nearly Jevel } \\
\text { and in } \\
\text { depressions. }\end{array}$ & $\begin{array}{l}\text { Runof slow; } \\
\text { ponded in } \\
\text { places; Jow } \\
\text { in phosphorus } \\
\text { and potas } \\
\text { sium. }\end{array}$ & $\begin{array}{l}\text { Shrlnk-swell po- } \\
\text { tential moder- } \\
\text { ate in subsoil } \\
\text { and low below } \\
\text { a depth of } 31 / 2 \\
\text { feet; seasonal } \\
\text { high water } \\
\text { table. }\end{array}$ & $\begin{array}{l}\text { Severe: seasonal } \\
\text { high water } \\
\text { table; subject } \\
\text { to ponding; } \\
\text { slow permea- } \\
\text { bility. }\end{array}$ & Slight. \\
\hline $\begin{array}{l}\text { Moderate permea- } \\
\text { bility; fair sta- } \\
\text { bility; fair con- } \\
\text { paction; subject } \\
\text { to flooding. }\end{array}$ & Well drained...- & $\begin{array}{l}\text { Nearly level; } \\
\text { on flood } \\
\text { plains. }\end{array}$ & $\begin{array}{l}\text { Nearly level; } \\
\text { on flood } \\
\text { plains. }\end{array}$ & $\begin{array}{l}\text { On flood plains and } \\
\text { subject to } \\
\text { flooding. }\end{array}$ & $\begin{array}{l}\text { Severe: subject } \\
\text { to flooding. }\end{array}$ & $\begin{array}{l}\text { Severe: subject } \\
\text { to flooding. }\end{array}$ \\
\hline $\begin{array}{l}\text { Fair stability and } \\
\text { fair to good } \\
\text { compaction in } \\
\text { subsoil; good } \\
\text { stability and } \\
\text { compaction in } \\
\text { substratum; } \\
\text { contains loose } \\
\text { gravel and sand. }\end{array}$ & $\begin{array}{l}\text { Seasonal high } \\
\text { water table; } \\
\text { sand and } \\
\text { gravel below } \\
\text { a depth of } 24 \\
\text { to } 40 \text { inches. }\end{array}$ & $\begin{array}{l}\text { Nearly level } \\
\text { and in } \\
\text { depressions. }\end{array}$ & $\begin{array}{l}\text { Very poorly } \\
\text { drained; } \\
\text { wetness. }\end{array}$ & $\begin{array}{l}\text { Shrink-swell } \\
\text { potential } \\
\text { moderate in } \\
\text { subsoil and low } \\
\text { at a dejth of } \\
24 \text { to } 40 \text { inches; } \\
\text { seasonal high } \\
\text { water table. }\end{array}$ & $\begin{array}{l}\text { Severe: seasonal } \\
\text { high water } \\
\text { table; possi- } \\
\text { ble stream } \\
\text { pollution } \\
\text { through loose } \\
\text { gravel and sand. }\end{array}$ & $\begin{array}{l}\text { Severe: } \\
\text { gravelly in } \\
\text { lower =ub- } \\
\text { soil; low-e } \\
\text { gravel and } \\
\text { sind at a } \\
\text { deph h of :- } \\
\text { to } 40 \text { incliew. }\end{array}$ \\
\hline $\begin{array}{l}\text { Fair stability and } \\
\text { compaction; } \\
\text { subject to } \\
\text { foorlink: Inclium } \\
\text { compromilsility. }\end{array}$ & $\begin{array}{l}\text { Seasonal high } \\
\text { water talile; } \\
\text { subject to } \\
\text { tluodink. }\end{array}$ & $\begin{array}{l}\text { Nearly level; } \\
\text { on flood } \\
\text { julains. }\end{array}$ & $\begin{array}{l}\text { Sonewhat } \\
\text { poorly } \\
\text { dralned; } \\
\text { wetness. }\end{array}$ & $\begin{array}{l}\text { Scasonal hlgh } \\
\text { water talile; on } \\
\text { nond jlaing } \\
\text { und sulject to } \\
\text { llooding. }\end{array}$ & $\begin{array}{l}\text { Severc: anbject } \\
\text { to floodingi } \\
\text { seavonal ligh } \\
\text { water talsle. }\end{array}$ & $\begin{array}{l}\text { Severe: } \\
\text { suliject to } \\
\text { hoordins. }\end{array}$ \\
\hline
\end{tabular}


TABLE 万.-Inquimelin!

\begin{tabular}{|c|c|c|c|c|c|}
\hline \multirow{2}{*}{ Soil series and map symbols } & \multicolumn{3}{|c|}{ Suitability as a sourec of- } & \multicolumn{2}{|c|}{ Soil features aflecting-- } \\
\hline & Topsoil & Sand and gravel & Road fill & Highway location & Reservoir area \\
\hline $\begin{array}{l}\text { Sloan: } \\
\qquad \text { Sn } \ldots \ldots \ldots \ldots\end{array}$ & $\begin{array}{l}\text { Fuir or good to a } \\
\text { deptli of } 12 \\
\text { inches; poor } \\
\text { below; viriable } \\
\text { stratified layers; } \\
\text { gravelly. }\end{array}$ & Not suitable_... & $\begin{array}{l}\text { Fair to poor: sub- } \\
\text { ject to frost } \\
\text { heaving and } \\
\text { flooding; seasonal } \\
\text { high water table. }\end{array}$ & $\begin{array}{l}\text { Subject to flooding; } \\
\text { seasonal high } \\
\text { watcr table; } \\
\text { subject to frost } \\
\text { henving. }\end{array}$ & $\begin{array}{l}\text { Seusonal higl water } \\
\text { tuble; suljeet to } \\
\text { flooding; slow } \\
\text { secpage. }\end{array}$ \\
\hline $\begin{array}{l}\text { Wallkill: } \\
\qquad \text { Wa..... }\end{array}$ & $\begin{array}{l}\text { Good to a depth } \\
\text { of } 10 \text { to } 20 \\
\text { inches. }\end{array}$ & Not suitable.... & Not suitable ....... & $\begin{array}{l}\text { Organic material at } \\
\text { a depth below } 10 \\
\text { to } 20 \text { inches; } \\
\text { unstable; sulject } \\
\text { to ponding. }\end{array}$ & $\begin{array}{l}\text { Organic mnterial; } \\
\text { high watcr table. }\end{array}$ \\
\hline
\end{tabular}


interpretations of the soils-Continued

\begin{tabular}{|c|c|c|c|c|c|c|}
\hline \multicolumn{5}{|c|}{ Soil features affeeting-Continued } & \multicolumn{2}{|c|}{ Litnitations for sewage di॰po-..l } \\
\hline Einbankment & $\begin{array}{l}\text { Agricultural } \\
\text { drainage }\end{array}$ & $\begin{array}{l}\text { Terraces } \\
\text { and } \\
\text { diversions }\end{array}$ & $\begin{array}{c}\text { Grassed } \\
\text { waterways }\end{array}$ & $\begin{array}{l}\text { Foundations } \\
\text { for low } \\
\text { buildings }\end{array}$ & $\begin{array}{l}\text { Septic tank } \\
\text { filt(cr fields }\end{array}$ & Sewage lagorn. \\
\hline $\begin{array}{l}\text { Fair stability and } \\
\text { compaction; } \\
\text { subject to } \\
\text { flooding; mediun } \\
\text { compressibility. }\end{array}$ & $\begin{array}{l}\text { Seasonal ligh } \\
\text { water table; } \\
\text { subject to } \\
\text { flooding. }\end{array}$ & $\begin{array}{l}\text { Nearly level } \\
\text { and In } \\
\text { depressions; } \\
\text { flood } \\
\text { plains. }\end{array}$ & $\begin{array}{l}\text { Runoff very } \\
\text { slow; } \\
\text { wetness. }\end{array}$ & $\begin{array}{l}\text { Shrink-swell } \\
\text { potential } \\
\text { moderate in } \\
\text { subsoil and low } \\
\text { below a depth } \\
\text { of } 3 \text { feet; } \\
\text { subject to } \\
\text { flooding and } \\
\text { ponding; } \\
\text { seasonal high } \\
\text { water table; } \\
\text { moderately slow } \\
\text { permeability. }\end{array}$ & $\begin{array}{l}\text { Severe: scasoual } \\
\text { high water } \\
\text { table; subject } \\
\text { to flooding; } \\
\text { moderately slow } \\
\text { permeatility. }\end{array}$ & $\begin{array}{l}\text { Severe: } \\
\text { sulljeet to } \\
\text { flooding. }\end{array}$ \\
\hline $\begin{array}{l}\text { Organic material } \\
\text { at a depth below } \\
10 \text { to } 20 \text { inches; } \\
\text { subject to } \\
\text { ponding. }\end{array}$ & $\begin{array}{l}\text { IIigh water } \\
\text { Iable; subjeet } \\
\text { to ponding; } \\
\text { poor outlets. }\end{array}$ & $\begin{array}{l}\text { In depres- } \\
\text { sions. }\end{array}$ & $\begin{array}{l}\text { Level; very } \\
\text { poorly } \\
\text { drained. }\end{array}$ & $\begin{array}{l}\text { Unstable organic } \\
\text { material below } \\
\text { a depth of } 10 \\
\text { to } 20 \text { inches; } \\
\text { high water } \\
\text { table; subject } \\
\text { to ponding. }\end{array}$ & $\begin{array}{l}\text { Severe: high } \\
\text { water table; } \\
\text { subject to } \\
\text { ponding; } \\
\text { organic } \\
\text { material bclow } \\
\text { a depth of } 10 \\
\text { to } 20 \text { inches. }\end{array}$ & $\begin{array}{l}\text { Severe: higl } \\
\text { content of } \\
\text { organic } \\
\text { matter; Iow } \\
\text { and fre- } \\
\text { quently } \\
\text { ponded; } \\
\text { drainage frum } \\
\text { higher urcio. }\end{array}$ \\
\hline
\end{tabular}




$$
J H R P r+1 ?
$$



CLAYEY TEXTURE
(PROFILE SET NO.1)

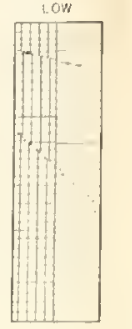

RIDGE AND GROUND MORAINE CLAYEY TO SILTY TEXTURE
(PROFILE SET NO 2)
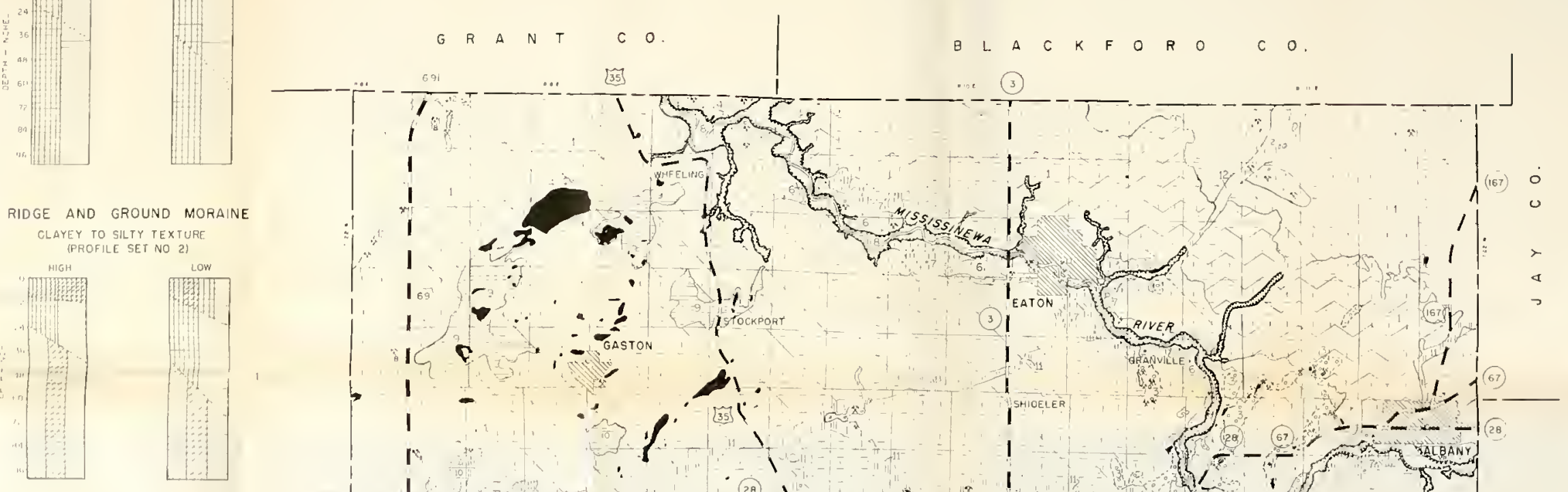

ESKERS AND KAMES GRAVEL ANO SANO TEX TUR
(PROFILE NO. 3)

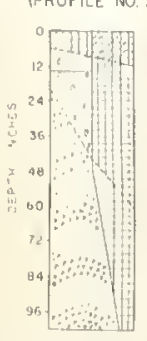

OUTWASH PLAINS Sano ano gravel SANo ano SiL-T

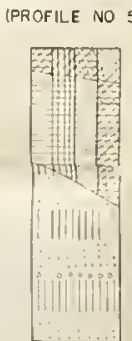

TERRACES AND VALLEY TRAINS SANO ANO GRAVEL GRAVELIY SILT LOAM
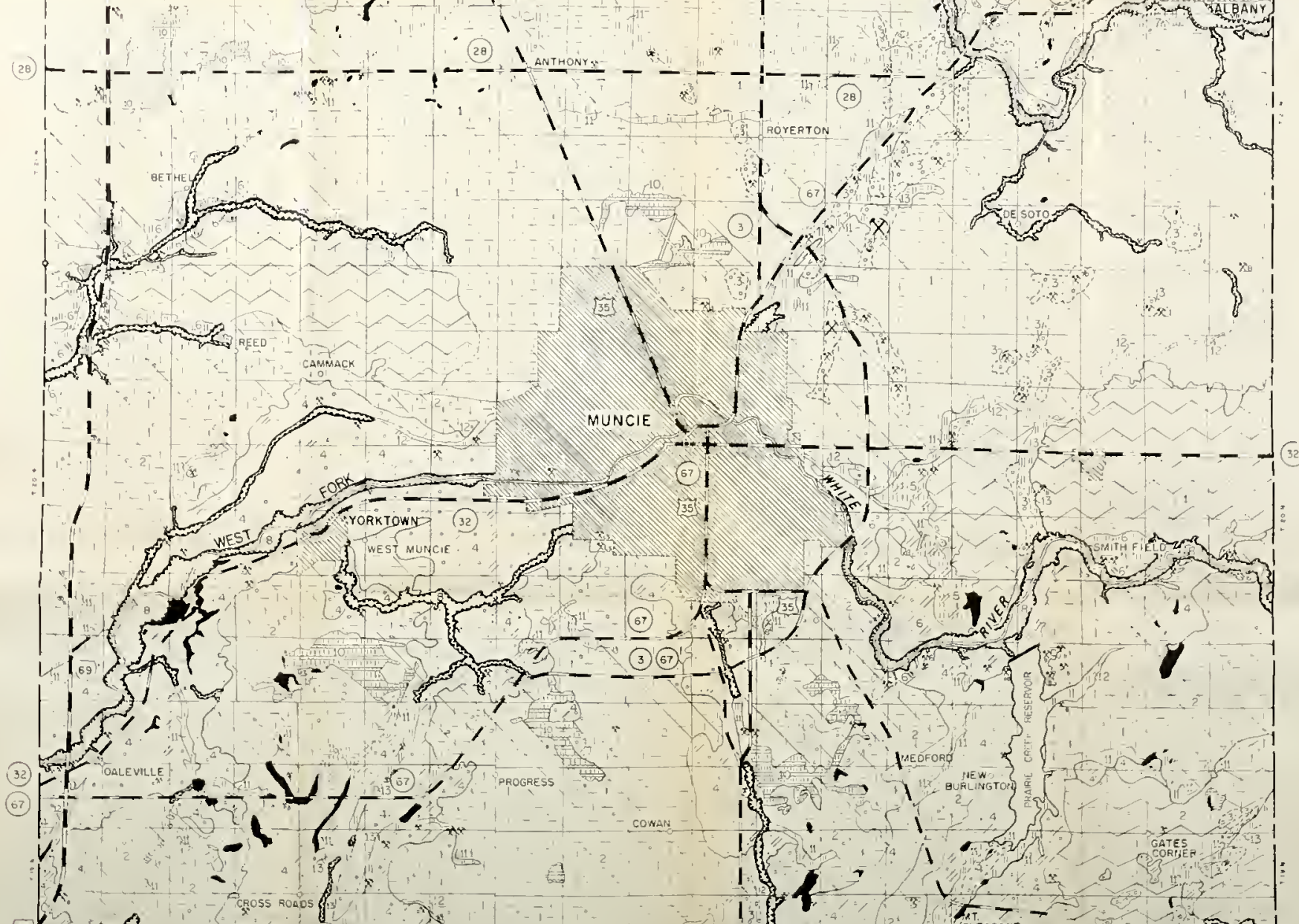

MISCELLANEOUS

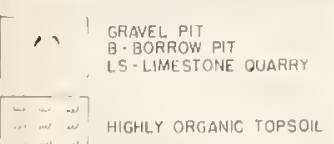

TEXTURAL SYMBOLS ISUPERIMPOSEO ON PARENT MATE RIAL
SYMBOLS TO SHOW RELATIVE GOMPOSITIONN H:S GRave

TEXTURAL SYMBOLS

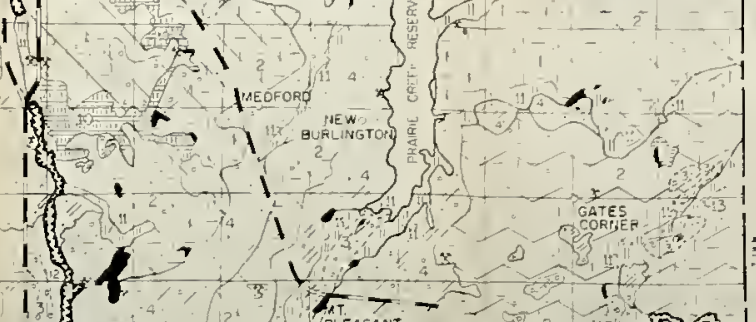


SanO ANO GRAEL SANO ANO SILT

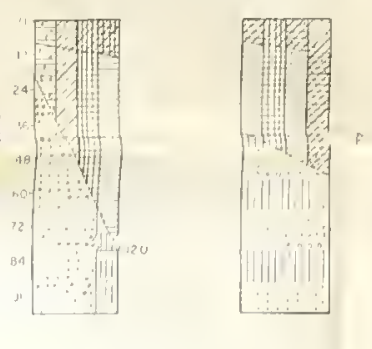

TERRAGES AND VALLEY TRAINS ANO ANO GRAVEL GRAVELLY SILT LOAM

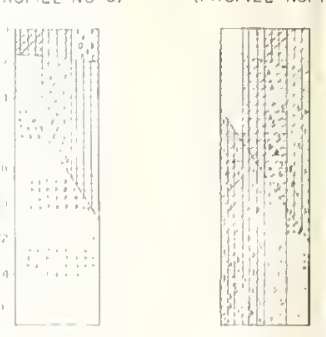

$\therefore$.

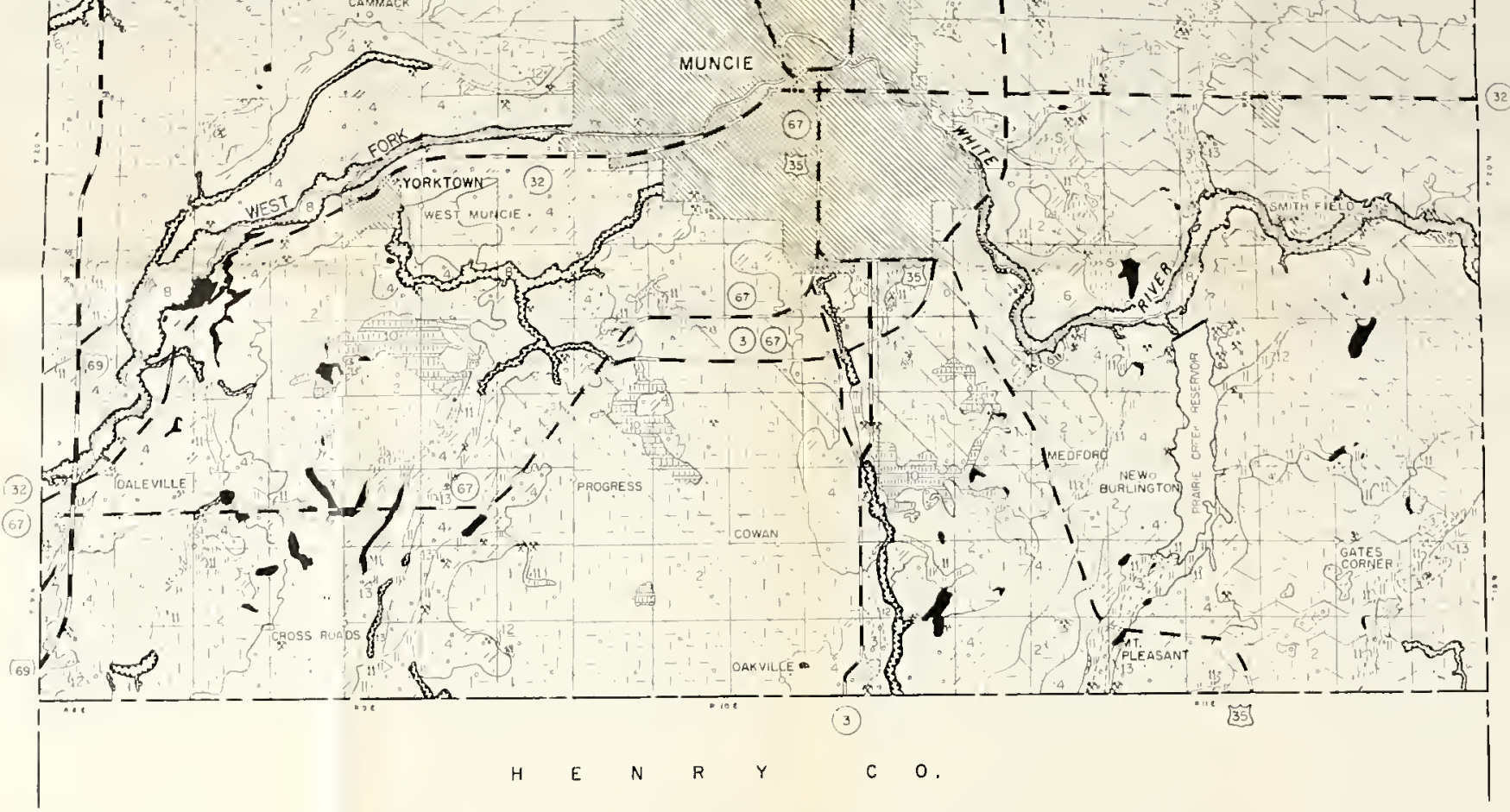

ALLUVIAL PLAINS

SILT ANO SANO TEXTURE
(PROFILE SET NO. B)

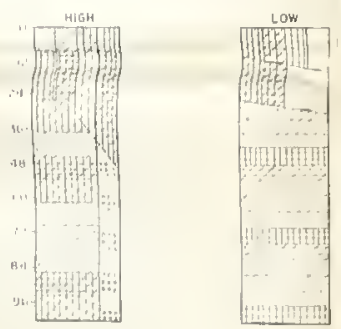

LACUSTRINE PLAINS

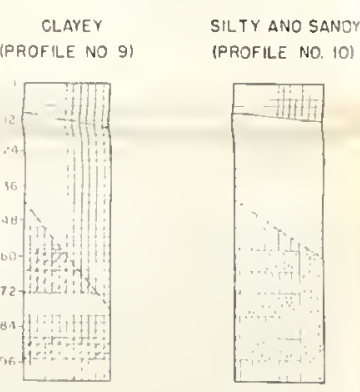

GLACIAL SLUICEWAYS - NARROW VALLEY TRAINS

SANOY ANO SLLYY GRAVELLY SILT LOAM

GLAYEY
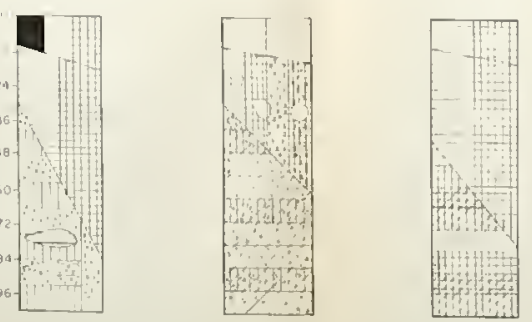

PEAT ANO MUCK

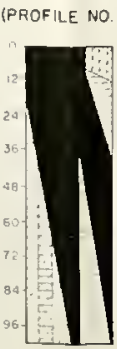

ENGINEERING SOILS MAP

\section{DELAWARE COUNTY}

\section{INDIANA}

1941 AAA AERIAL PHOTOGRAPHS

JOINT HIGHWAY RESEARCH PROJECT

PURDUE UNIVERSITY

1969

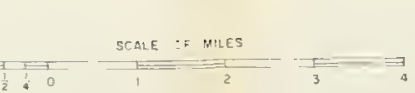


